\title{
The Climatic and Hydrologic History of Southern Nevada During the Late Quaternary
}

By R.M. Forester ${ }^{1}$, J.P. Bradbury ${ }^{2}$, C. Carter ${ }^{3}$, A.B. Elvidge-Tuma ${ }^{4}$, M.L. Hemphill ${ }^{5}$, S.C. Lundstrom ${ }^{1}$, S.A. Mahan ${ }^{1}$, B.D. Marshall, L.A. Neymark ${ }^{6}$, J.B. Paces ${ }^{1}$, S.E. Sharpe ${ }^{7}$, J.F. Whelan ${ }^{1}$, and P.E. Wigand ${ }^{8}$

${ }^{1}$ USGS, Denver, CO, ${ }^{2}$ USGS, Denver, CO (retired), ${ }^{3}$ USGS, Menlo Park, CA (retired), ${ }^{4} 1725$ S. McCarren, Reno, NV, ${ }^{5}$ Department of Anthropology, Washington State University, Pullman, WA, ${ }^{6}$ Pacific Western Technologies Ltd., Lakewood, CO, ${ }^{7}$ Nevada Division of Water Planning, 1550 E. College Parkway, Suite 142, Carson City, NV, ${ }^{8} 2210$ Seneca Drive, Reno, NV

U.S. GEOLOGICAL SURVEY

Open-File Report 98-635

Prepared in cooperation with the NEVADA OPERATIONS OFFICE U.S. DEPARTMENT OF ENERGY (Interagency Agreement DE-A108-97NV12033) 


\section{U.S. DEPARTMENT OF THE INTERIOR \\ BRUCE BABBITT, Secretary}

U.S. GEOLOGICAL SURVEY

Charles G. Groat, Director

The use of firm, trade, and brand names in this report is for identification purposes only and does not constitute endorsement by the U.S. Geological Survey.

For additional information write to:

Chief, Earth Science Investigations Program

Yucca Mountain Project Branch

U.S. Geological Survey

Box 25046, Mail Stop 421

Denver Federal Center

Denver, CO 80225-0046
Copies of this report can be purchased from:

U.S. Geological Survey

Information Services

Box 25286

Federal Center

Denver, CO 80225 


\section{CONTENTS}

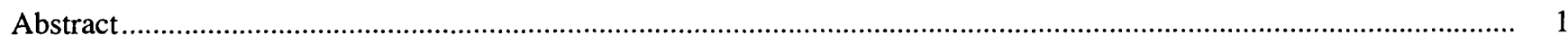

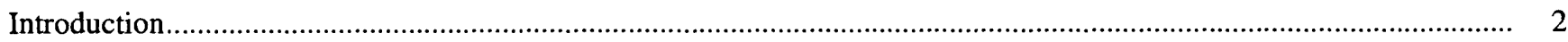

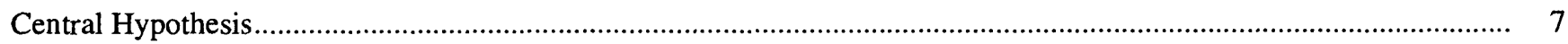

Causation and Nature of Climate and Hydrological Change in Southern Nevada—The Present and Past Climate System 8

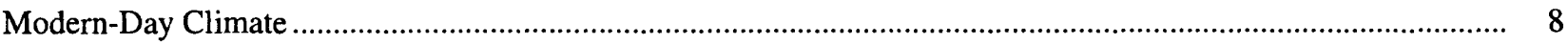

Past Climate-Nature of Climate Change ........................................................................................... 9

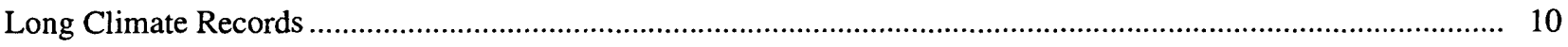

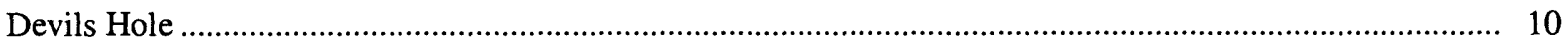

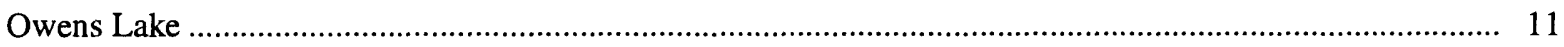

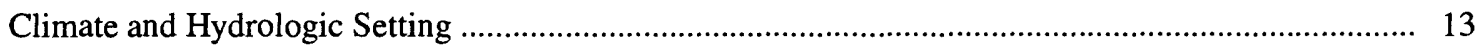

Climate Linkage to Owens Lake Chemistry and Paleontology .......................................................... 13

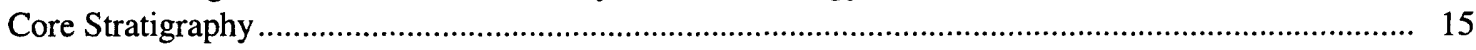

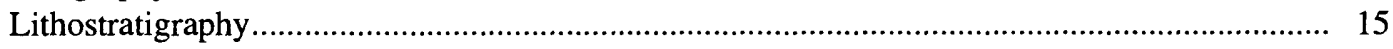

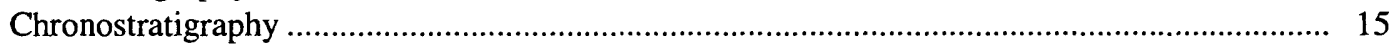

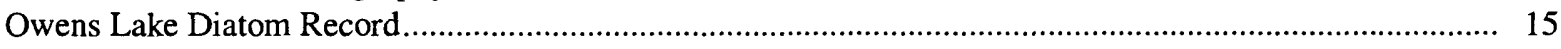

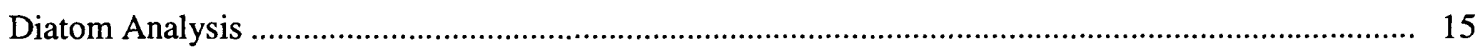

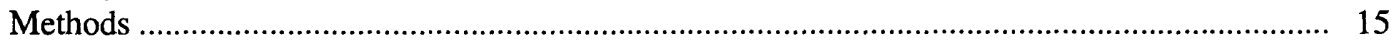

Paleohydrologic History of Owens Lake —The Diatom Record .............................................. 16

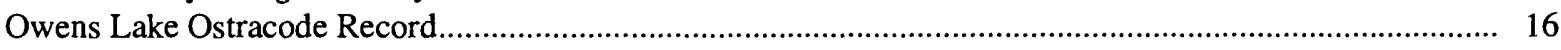

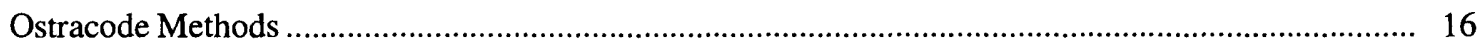

Paleolimnological History of Owens Lake - The Ostracode Record ............................................. 16

Correlation of Owens Lake Paleolimnology and Oxygen Isotope Records ........................................... 18

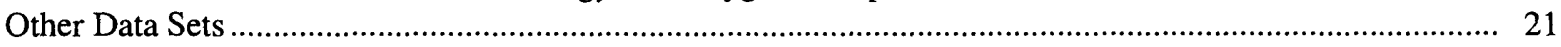

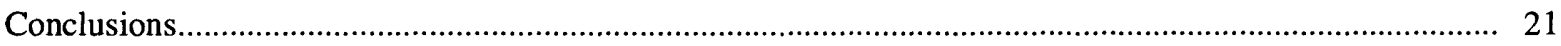

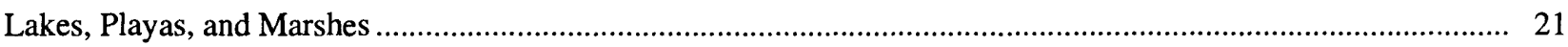

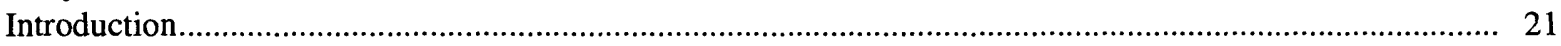

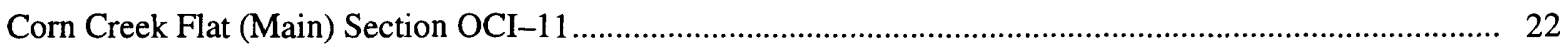

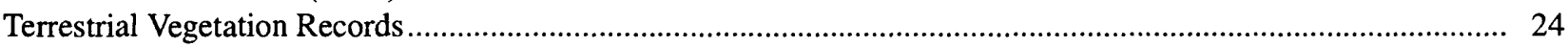

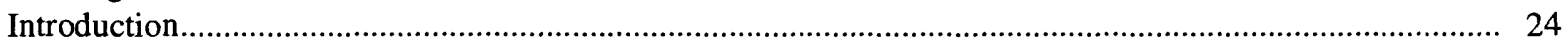

Modern Climate and Vegetation of Southern Nevada Deserts ........................................................... 24

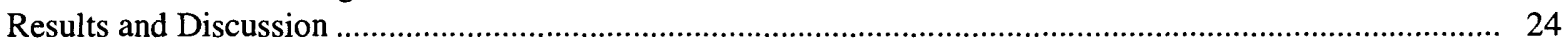

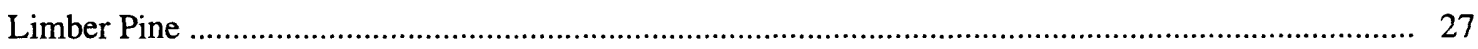

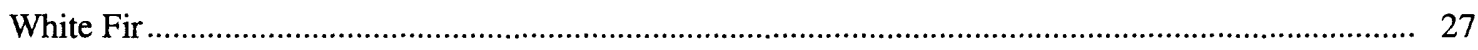

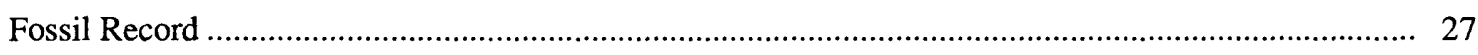

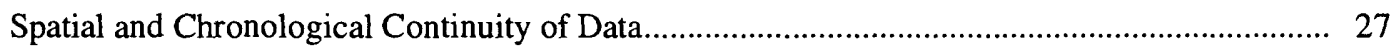

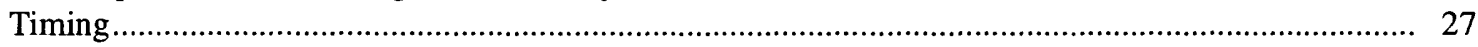

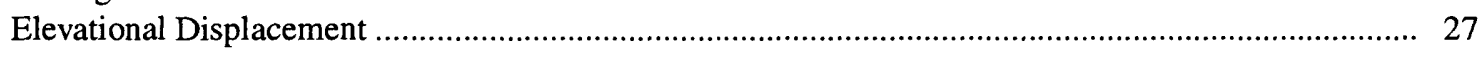

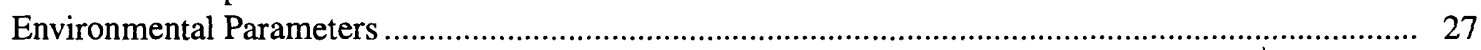

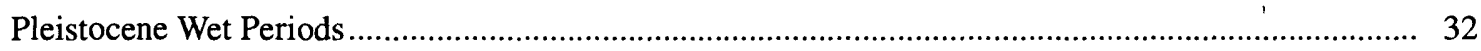

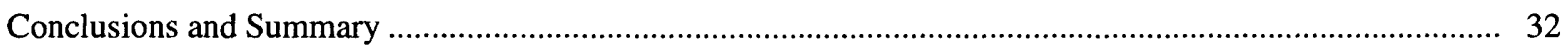

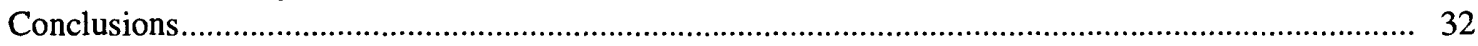

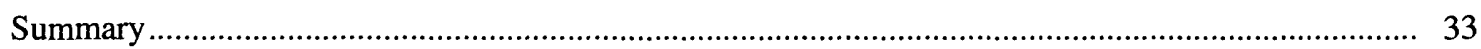

Comparison of Aquatic and Terrestrial Records..................................................................... 33

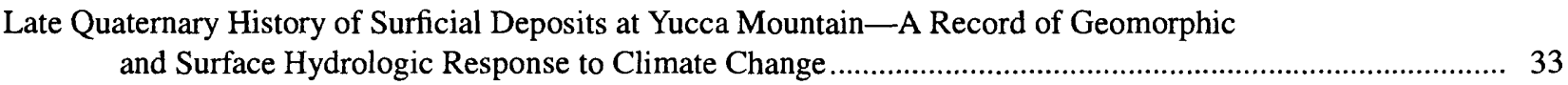

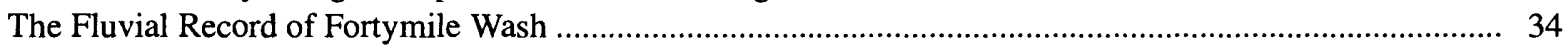

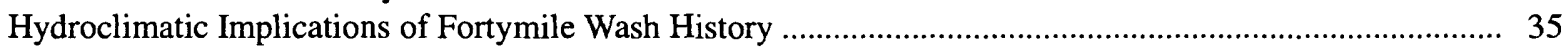

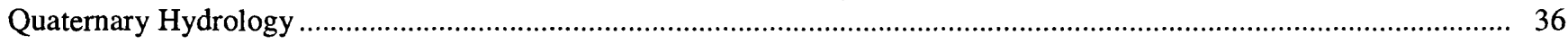

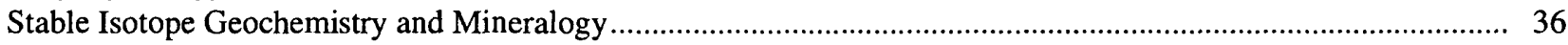

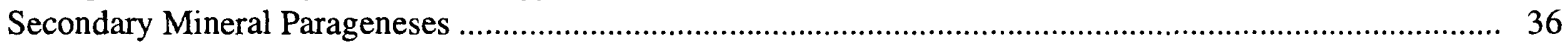

Isotopic Geochemistry of Unsaturated-Zone Secondary Calcite .............................................................. 37 
Conclusions

Linkage Between Paleohydrology and Strontium Isotopes........................................................................ 39

The Saturated Zone at Yucca Mountain and Changes in the Water-Table Position ...................................... 39

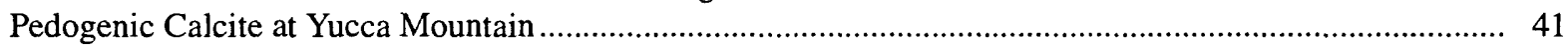

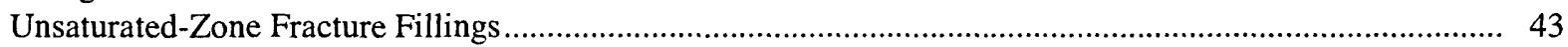

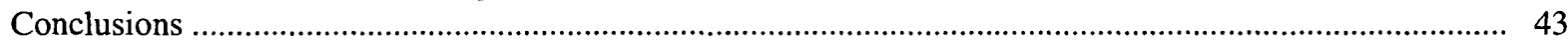

Geochronologic Studies of Calcite and Opal Deposits in the Exploratory Studies Facility ................................. 43

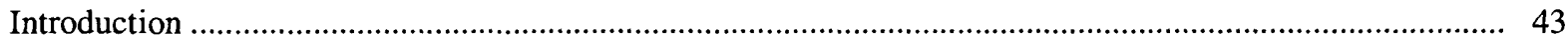

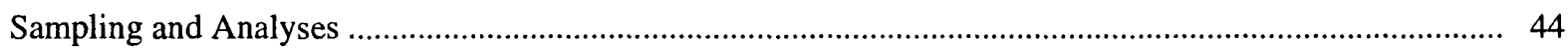

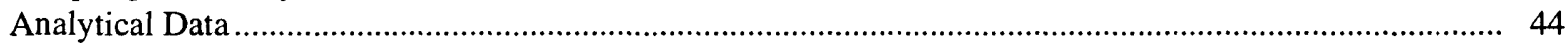

Distributions of Ages and Correlation with Climate Cycles ............................................................ 46

Past Ground-Water Discharge and Late Pleistocene Fluctuations in Water-Table Elevations .................................. 46

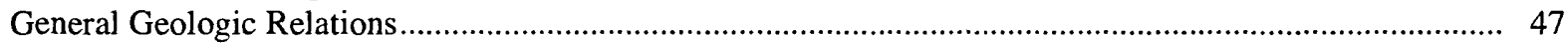

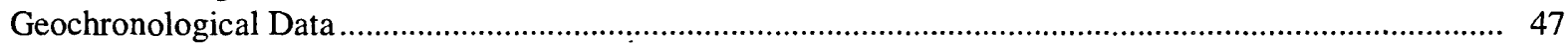

Paleontological Data and Paleoenvironmental Conditions....................................................................... 51

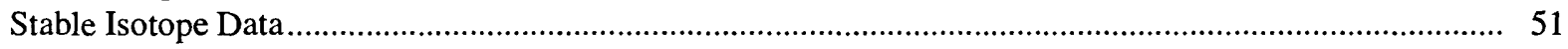

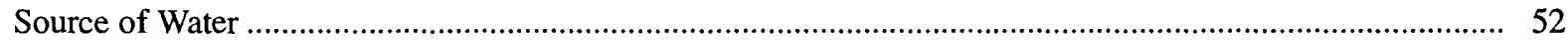

Water-Table Fluctuations Under Yucca Mountain................................................................................ 55

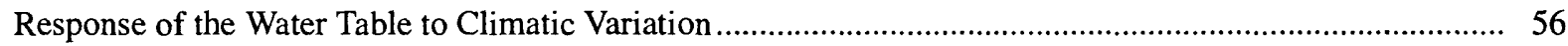

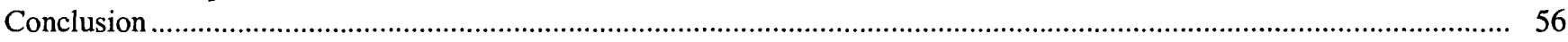

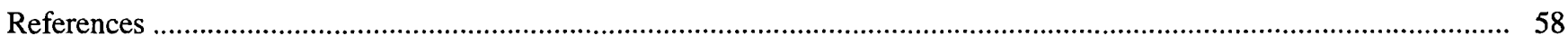

\section{FIGURES}

1. Locality map showing key study sites near Yucca Mountain.

2. Maps of $(A)$ southeastern Yucca Mountain showing potential repository site, sample boreholes and Exploratory Studies Facility; $(B)$ outcrop area of Lathrop Wells deposits showing sample localities;

$(C)$ studied outcrops in southeastern Crater Flat showing sample localities; and $(D)$ parts of outcrop area of, and sample localities in, Corn Creek Flats deposits

3. Generalized depiction of a three-celled circulation pattern of the Northern Hemisphere ..........................................

4-10. Graphs showing:

4. Common orbital parameters, eccentricity versus precession, and precession versus insolation plotted against a time axis

5. Comparison of the delta oxygen-18 record from Devils Hole to other climate records (SPECMAP and Vostok), as well as with the insolation plotted against a time axis..

6. Relative abundance of various kinds of diatoms from Owens Lake, California ............................................. 16

7. Relative abundance of various ostracode species found in Owens Lake, California, plotted against a generalized lithologic column

8. Comparison of the freshwater planktic diatom stratigraphic distribution from Owens Lake to the SPECMAP and Devils Hole records

9. Comparison of key ostracode species stratigraphic profiles from Owens Lake to the SPECMAP and Devils Hole climate records

10. Comparison of the stratigraphic distribution of key kinds of ostracodes to their stratigraphic record .............. 23

11. Index map showing Southern Nevada woodrat-midden localities mentioned in this study identified ..................... 26

12. Graph showing chronologic plot of the elevational distribution of directly dated limber pine macrofossils from ancient woodrat middens from a $200-\mathrm{km}$ radius around Yucca Mountain; radiocarbon dates on limber pine for this study plotted as a normal distribution at three standard deviations around the mean; and radiocarbon dates on limber pine for other studies plotted as a normal distribution at three standard deviations around the mean ..... 
13. Chronologic plot of the elevational distribution of directly dated white fir macrofossils from ancient woodrat middens from a 200-km radius around Yucca Mountain; radiocarbon dates on white fir for this study plotted as a normal distribution at three standard deviations around the mean; and radiocarbon dates on white fir for other studies plotted as a normal distribution at three standard deviations around the mean

14. Graphs showing the distribution of directly dated limber pine, white fir, Utah juniper, and pinyon pine through time and by elevation from ancient woodrat middens from a $200-\mathrm{km}$ radius around Yucca Mountain

15. Graph showing plot of delta carbon-13 and delta oxygen-18 values of calcite versus depth within the unsaturated zone

16. Histogram showing the distribution of unsaturated-zone secondary calcite delta carbon-13 values

17. Graph showing strontium isotopic composition of calcite deposited at Devils Hole spring as a function of age ..... 40

18. Graph showing strontium-87/86 ratios in calcites from various core holes as a function of depth relative to the depth of the water table in the core holes sampled

19. Schematic model for the strontium data on the pedogenic carbonate system

20. Histograms of apparent radiocarbon and thorium-230/uranium ages determined from calcites and opals from the Exploratory Studies Facility

21. Location map showing paleodischarge deposits

22. Map showing ages determined by thorium-230/uranium, radiocarbon, and thermoluminescence methods for samples from paleodischarge sites.

23. Graph showing stable carbon and oxygen isotopic compositions of carbonates from the paleodischarge deposits that are the focus of this report plotted with different symbols representing each of the five sites

24. Map showing location of wells and springs analyzed for delta strontium-87 from waters.

\section{TABLES}

1. Modern vegetation distributions within the Yucca Mountain area

2. Plant contents of radiocarbon-dated middens at key localities around southern Nevada

3. Characteristic isotopic compositions of paleodischarge deposits, waters, and rocks representing possible source materials

4. Matrix of possible hydrogenic sources and their compatibility with observed data from paleodischarge sites.... 
CONVERSION FACTORS, VERTICAL DATUM, AND ABBREVIATIONS

Table 1:

\begin{tabular}{|r|l|l|}
\hline Multiply & \multicolumn{1}{|c|}{ By } & To obtain \\
\hline \hline centimeter $(\mathrm{cm})$ & 0.3937 & inch \\
\hline centimeter per thousand years $(\mathrm{cm} / \mathrm{ky})$ & 0.3937 & inch per thousand years \\
\hline gram $(\mathrm{g})$ & 0.03527 & ounce \\
\hline kilometer $(\mathrm{km})$ & 0.6214 & mile \\
\hline meter $(\mathrm{m})$ & 3.281 & foot \\
\hline meter per year $(\mathrm{m} / \mathrm{yr})$ & 3.281 & foot per year \\
\hline milligram $(\mathrm{mg})$ & $2.2 \times 10^{-6}$ & pound \\
\hline milligram per liter $(\mathrm{mg} / \mathrm{L})$ & 1 & part per million $(\mathrm{ppm})$ \\
\hline millimeter $(\mathrm{mm})$ & 0.03937 & inch \\
\hline square kilometer $\left(\mathrm{km}{ }^{2}\right)$ & 0.3861 & square mile \\
\hline
\end{tabular}

Temperature in degrees Celsius $\left({ }^{\circ} \mathrm{C}\right)$ may be converted to degrees Fahrenheit $\left({ }^{\circ} \mathrm{F}\right)$ as follows:

$$
{ }^{\circ} \mathrm{F}=\left(1.8 \times{ }^{\circ} \mathrm{C}\right)+32
$$

\section{ADDITIONAL ABBREVIATIONS}

millions of years (My)

millions of years before present $(\mathrm{Ma})$

thousand years before present $(\mathrm{ka})$

thousands of years (ky)

Sea level: In this report, "sea level" refers to the National Geodetic Vertical Datum of 1929 (NGVD of 1929)-a geodetic datum derived from a general adjustment of the first-order level nets of both the United States and Canada, formerly called Sea Level Datum of 1929. 


\section{The Climatic and Hydrologic History of Southern Nevada During the Late Quaternary}

By R.M. Forester ${ }^{1}$, J.P. Bradbury ${ }^{2}$, C. Carter $^{3}$, A.B. Elvidge-Tuma ${ }^{4}$, M.L. Hemphill ${ }^{5}$, S.C. Lundstrom ${ }^{1}$, S.A. Mahan ${ }^{1}$, B.D. Marshall ${ }^{1}$, L.A. Neymark ${ }^{6}$, J.B. Paces ${ }^{1}$, S.E. Sharpe ${ }^{7}$, J.F. Whelan ${ }^{1}$, and P.E. Wigand ${ }^{8}$

${ }^{1}$ USGS, Denver, CO, ${ }^{2}$ USGS, Denver, CO (retired), ${ }^{3}$ USGS, Menlo Park, CA (retired), ${ }^{4} 1725$ S. McCarren, Reno, NV, ${ }^{5}$ Department of Anthropology, Washington State University, Pullman, WA, ${ }^{6}$ Pacific Western Technologies Ltd., Lakewood, CO, ${ }^{7}$ Nevada Division of Water Planning, 1550 E. College Parkway, Suite 142, Carson City, NV, ${ }^{8} 2210$ Seneca Drive, Reno, NV

\section{Abstract}

Understanding climate change during the expected life span of a potential high-level nuclear-waste repository at Yucca Mountain, Nevada, requires estimates of future climate boundary conditions. Climate boundary conditions are governed by changes in the Earth's orbital properties (eccentricity, obliquity, precession) that determine insolation. Orbital properties and the resulting insolation values can be calculated for the past and the future, so estimates of future conditions can be made by comparison to comparable conditions in the past. The major, insolation-controlled climate cycle is 400,000 years in duration with subcycles of approximately 100,000 years. Changes in insolation are closely correlated with the major features of global climate change, such as the growth and retreat of continental ice sheets. The anticipated change in insolation during the next 100,000 years resembles change in insolation during the period from 400,000 to 300,000 years before the present.

The Devils Hole isotopic climate record shows that regional climate in southern Nevada changed in concert with global climate change, and long sedimentary records from basins, such as Owens Lake, provide an estimate of the character, magnitude, and frequency of local climate change. These records, therefore, link changes in insolation to a climate response in the Yucca Mountain area. Climate data collected from cores taken in the Owens Lake Basin show that the major glacial and interglacial features of climate history are represented in this nearly continuous sediment sequence deposited during the last 500,000 years. Interpretation of the Owens Lake climate record indicates the various glacial and interglacial periods differ in their climate characteristics. The last two glacial periods $(170,000$ to 140,000 years before the present, and 40,000 to 10,000 years before the present) appear to have been wetter and colder than the glacial interval from about 400,000 to 350,000 years before the present, which may serve as an analog for the next glacial period. Substantiation of the latter observation with additional analyses would be a significant finding for the probable performance of a potential repository, at least from a climate perspective.

Interpretation of plant macrofossils found in woodrat middens near Yucca Mountain indicates that mean annual precipitation varied during the last wet period 40,000 to 10,000 years ago, but precipitation was typically as much as twice the modern mean annual precipitation value. In particular, the midden data show short, century- to millennial-scale episodes when white fir moved to lower elevations. During those episodes, mean annual precipitation was probably greater than twice modern mean values. The variation of mean annual precipitation remains to be estimated, but given the diversity of dry and wet plant types within various middens, the variation in mean annual precipitation was likely quite large. Present mean annual precipitation at Yucca Mountain is about $15 \mathrm{~cm}$. Episodes without white 
fir often contain limber pine, which, in addition to drier conditions, indicates very cold mean annual temperature, perhaps as low as 4 to $5^{\circ} \mathrm{C}$. Summer mean temperatures also would have been low, below about $16^{\circ} \mathrm{C}$.

Ostracode species found in sediments from former ground-water and spring-dischargesupported wetlands, such as those in the Las Vegas Valley, indicate a higher than modern level of effective moisture. These aquatic fossils together with the plant macrofossil data indicate that gains in effective moisture typically were due to deep depressions in mean annual temperature, with only modest gains in mean annual precipitation. During the apparently wetter white fir intervals, however, gains in effective moisture probably had a significant mean annual precipitation component in combination with lowered mean annual temperature.

Geomorphic studies of the alluvial fans and fluvial deposits in and around Fortymile Wash show a response to past-climate change. Alluvial and fluvial sediments were deposited during the wetter phases of interglacial periods and periods of transitional climates when infrequent but large storms eroded the hillslopes, including those of Yucca Mountain. Incision of those sediments occurred during cooler and wetter climate phases when hillslopes, which were stabilized by vegetation, supplied little sediment to the regular flow in Fortymile Wash. Deposition (drier climate) of sediment in the wash occurred from about 120,000 to about 50,000 years ago, and incision (wetter climate) occurred after this period and likely before the last glacial maxima period, about 18,000 radiocarbon years before the present.

Geochronologic, isotopic, geochemical, and petrographic studies of calcite and opal minerals precipitated within fractures inside Yucca Mountain provide a direct means of comparing past regional climates to changes in infiltration, percolation, and recharge within the unsaturated zone. Calcite and opal formation within the unsaturated zone (specifically beneath Yucca Mountain), based on stable carbon and oxygen isotopes and radiogenic strontium isotopes, comes from infiltration, as do perched water bodies within Yucca Mountain. Stable isotopic data from the unsaturated-zone calcites indicate the infiltration came during glacial periods when the regional vegetation was dominated by cold-tolerant plants. The infiltration seems to have had a maritime polar to arctic airmass signature and interacted with soil carbonates and probably other near-surface rocks. The data set for ages of secondary minerals, though preliminary, indicates little or no formation of secondary minerals during interglacial periods consistent with a glacial-mode origin for the infiltration and percolation.

Sedimentary deposits of former wetlands and springs found in valleys down the flow gradient from Yucca Mountain provide records of ground-water discharge during the last and probably the penultimate major wet-climate periods. Spring deposits at Crater Flat and at the Lathrop Wells Diatomite $20 \mathrm{~km}$ south of Yucca Mountain and paleowetland deposits near the Amargosa River show that discharge occurred between about 40,000 and 8,000 years before the present. The discharge, at least in part, came from the regional aquifer when the water tables rose to a maximum of about $100 \mathrm{~m}$ above present levels, as indicated from the depth to regional ground water at the Lathrop Wells diatomite site.

\section{INTRODUCTION}

Understanding how future climate change may affect the hydrologic-environment of a potential highlevel nuclear-waste repository at Yucca Mountain, Nevada, during its expected life span is the primary purpose of the climate studies. Study of long-term paleoclimate and paleohydrology provides a way to understand potential climatic and hydrologic variability on a time scale that is relevant to high-level nuclear waste isolation.

The present climate and hydrology of the Yucca Mountain, Nevada, area (figs. 1, 2, and 3) are coupled together as part of a long-term millennial-scale product of continuous, generally cyclical, climate change (fig. 4). The climate system responds to numerous short-term forcing functions, such as 


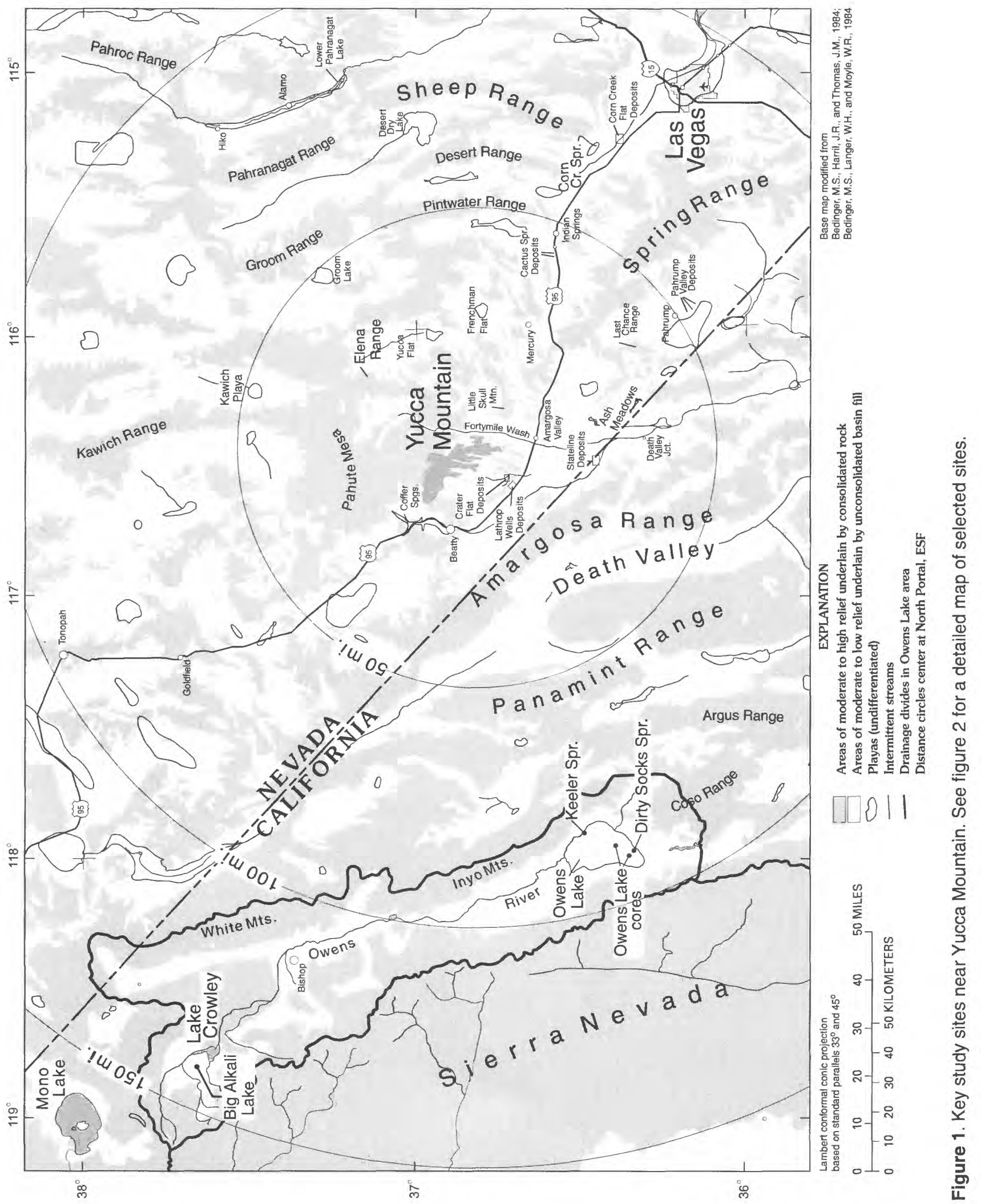



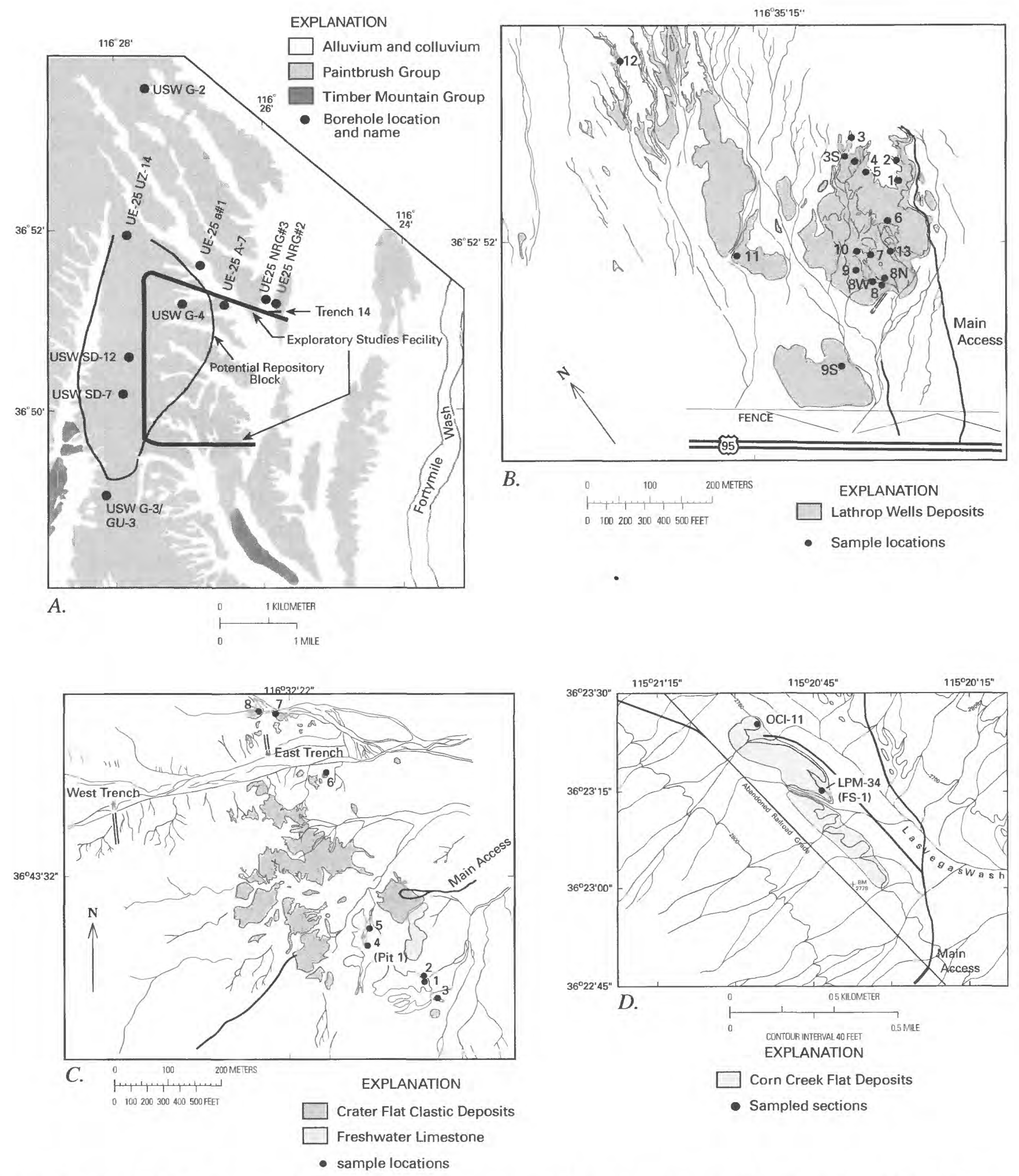

Figure 2. Maps of $(A)$ southeastern Yucca Mountain showing potential repository site, sample boreholes, and Exploratory Studies Facility; $(B)$ outcrop area of Lathrop Wells deposits showing sample localities; $(C)$ studied outcrops in southeastern Crater Flat showing sample localities; and $(D)$ parts of outcrop area of and sample localities in the Corn Creek Flats deposits. 


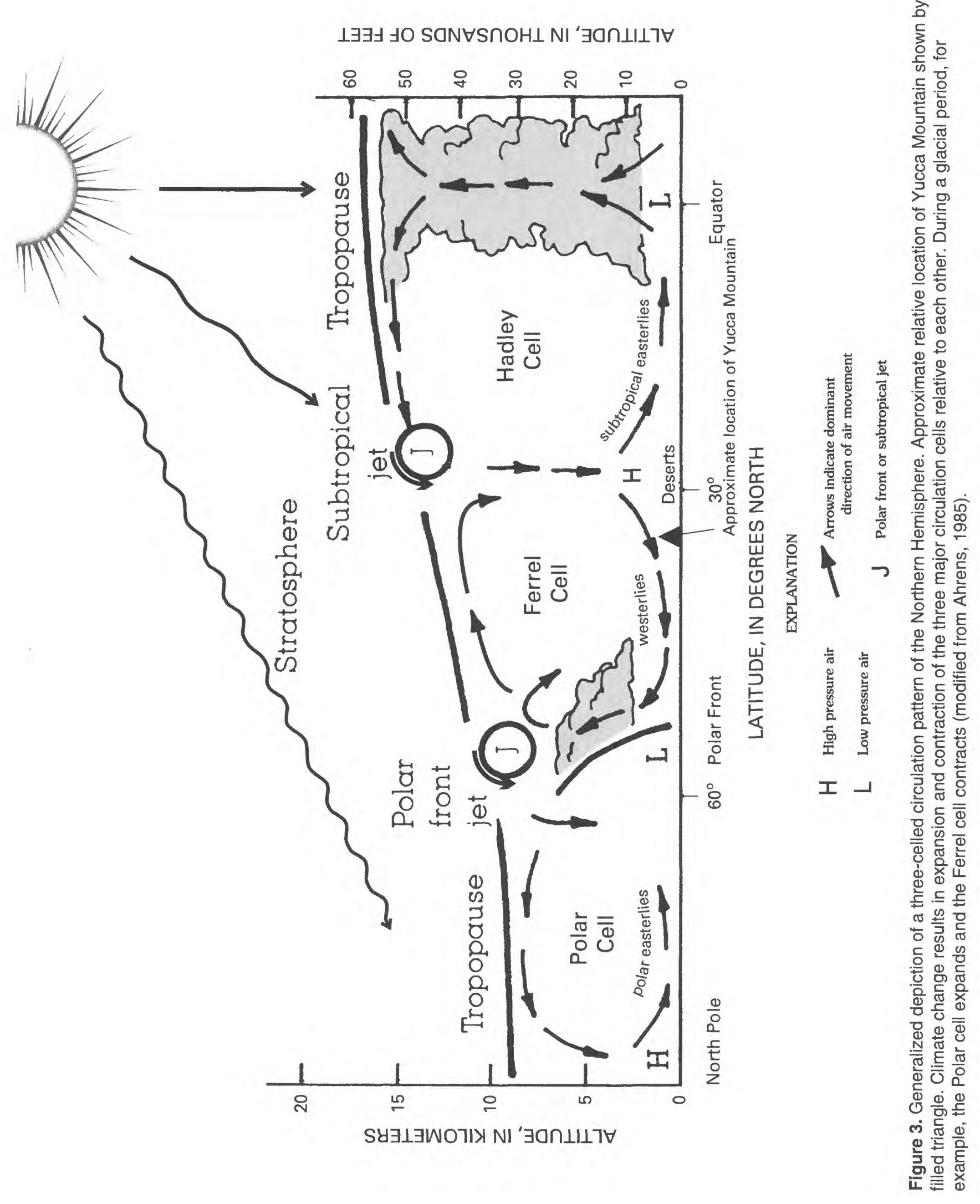



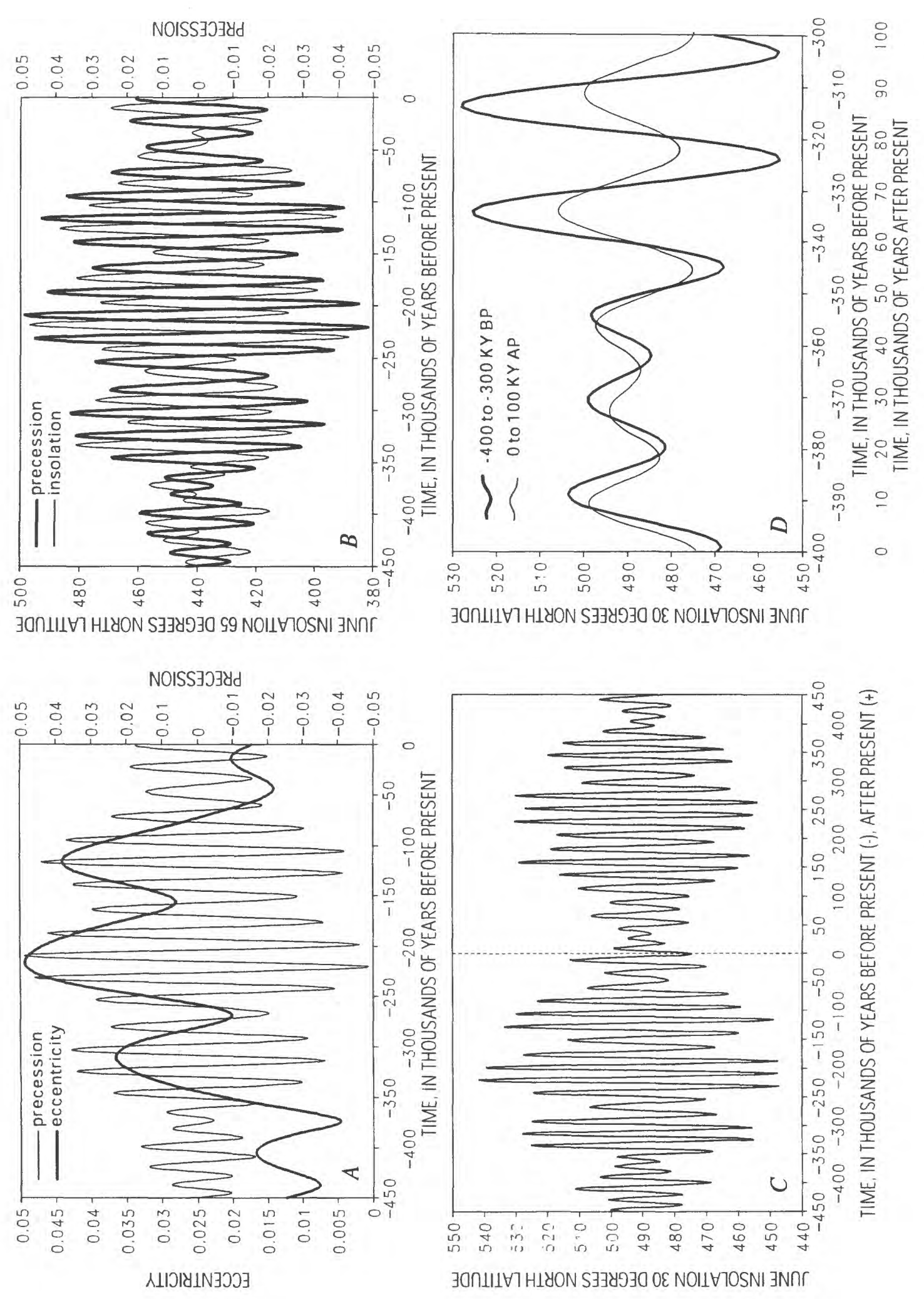

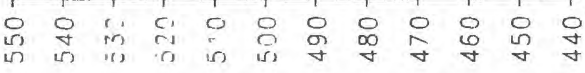

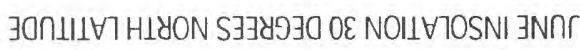

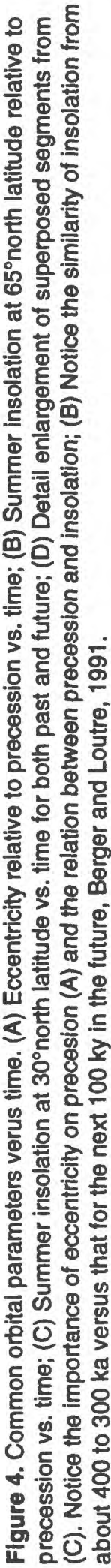


changes in solar output or volcanic eruptions. Shortterm forcing functions create variability in the climate system's mean behavior as it responds to longer-term forcing functions. On a millennial scale, the cyclical changes in insolation appear to be especially important correlates of climate change. In recent Earth history (the past 2 million years before the present or $2 \mathrm{Ma}$ ), changes in insolation are correlated with glacial and interglacial periods, with the glacial intervals being resident about 80 percent of the time. Climate also responds to very long-term forcing functions, over hundreds of thousands to millions of years, such as those related to continental drift or regional tectonics. As these very long-term forcing functions change, so does the mean millennial-scale character of climate. Regional hydrology, because it is coupled to climate, must respond to and change with climate. Thus, the millennial-scale characteristics of regional hydrology may be very different from those observed and measured over a short periods of time (decades to centuries). For example, southern Nevada regionalaquifer recharge was much higher during the last glacial period 40,000 to 10,000 years before the present, (40 to 10ka) than it is today (Benson and Kleiforth, 1989).

Evaluation of both past and future hydrologic characteristics of the potential high-level waste repository at Yucca Mountain cannot be based solely on modern hydrological studies. Although present-day studies reveal key characteristics details of the hydrological system, such as zones of infiltration, they cannot evaluate the characteristics of that system when major climate-system features, such as mean annual temperature (MAT), mean annual precipitation (MAP), and seasonal distributions of temperature and precipitation were different. The long-term millennialscale properties of the climate and hydrologic system are the subject of this report.

\section{CENTRAL HYPOTHESIS}

Future climate patterns at Yucca Mountain may be estimated by understanding the processes that link climate and hydrological change to the cyclic variation in the Earth's insolation. Change in insolation is an important correlate with change in the climate system on a millennial scale. Interpretation and dating of past climatic and hydrologic changes in the vicinity of Yucca Mountain provide a linkage with past orbital and insolation characteristics. Future changes in insolation are readily calculated from standard celestial mechanics (orbital parameters). Future insolationcorrelated climate patterns may therefore resemble those of past periods with similar insolation.

Climate responds to forcing functions that operate on all time scales from a year or less to millions of years. Short-term forcing functions involve factors, such as variability of solar output, of ocean/atmosphere heat exchange, such as the El Niño Southern Oscillation (ENSO), of volcanic eruptions, and of human-caused global warming. Long-term (million-year) forcing functions involve factors, such as continental drift, tectonics, and changes in ocean configuration. Change in Earth orbital characteristics occur on a millennial scale. Nonetheless, many factors must contribute to climate change, and the forcing functions likely operate on all time scales. As a consequence, future climate on the millennial scale almost certainly will not exactly repeat the past. Assuming that long-term Earth-based forcing functions, such as tectonics or ocean land configurations, remain relatively constant, however, changes in insolation should provide the timing for most future climate change for the next 100 millennia. That is, the characteristics of past climate cycles, within the confines of long-term Earth-based forcing functions, may repeat in the future and therein provide a basis to forecast future climate.

Present-day climate operates within a seasonal range of insolation values within which the influence of short-term forcing functions plays a key role. As the seasonal range of insolation changes, however, the short-term forcing functions, which are important at human scales, have no consistent bearing on the nature of future climate operating within other ranges of insolation values. Short-term forcing functions that operate in future climate states will perturb them in some way, just as they do the modern state, however. Similarly, because modern-day hydrology is linked strongly to modern-day climate, future hydrology cannot be estimated by studying only present hydrology or the hydrology at any particular time.

Because past climate and hydrology cannot be measured directly, proxy data must be interpreted in terms of climate or hydrology. Past climatic and hydrologic proxies typically come from fossil and isotopic data. Understanding the relation between an organism, which leaves a fossil record, and climate allows interpretation of past climate from fossils. Because the survival of any population relies on many 
biotic and abiotic factors other than climate, a particular biologic proxy may not reflect past climate in exactly the same way as another biotic proxy. Extraction of a climate signal from multiple proxies can produce a more realistic composite picture of past climate. In this study, the fossil data include plant macrofossils from woodrat middens, pollen, molluscs, ostracodes, diatoms, and fossil mammals.

Carbon, oxygen, strontium, and uranium isotopes offer additional climate and hydrological information. Isotopes reflect the characteristics of past surface and ground waters and provide insights into climate dynamics. More significantly, isotopic data provide information about percolating waters in the unsaturated zone (UZ) and ground waters in the saturated zone (SZ) and, hence, the linkage between the past climate and past hydrology.

The fossil and isotopic data are supported further by petrographic data collected from calcite and opaline vein fillings within Yucca Mountain, as well as from ground-water discharge deposits that occur down the flow gradient and from alluvial, fluvial, eolian, pedogenic, and related deposits on and near the mountain.

\section{CAUSATION AND NATURE OF CLIMATE AND HYDROLOGICAL CHANGE IN SOUTHERN NEVADA-THE PRESENT AND PAST CLIMATE SYSTEM}

\section{Modern-Day Climate}

Global climate may be thought of as the consequence of the atmosphere's attempt to balance a heat budget that is perpetually out of balance. Heat transport takes place in the oceans and the atmosphere. Throughout the year, the tropics receive more heat than the poles, demanding that the excess tropical heat moves toward the polar deficit.

Atmospheric heat transport from the tropics begins with rising air that moves poleward in the upper troposphere (lowest layer of the atmosphere), where it cools and typically sinks around $30^{\circ}$ to $35^{\circ} \mathrm{N}$ latitude (fig. 3). Air flowing southward in the upper troposphere also descends in this region. The barometric pressure of the descending air rises near the Earth's surface and its relative humidity falls, creating a belt of hot deserts at 30 to $35^{\circ} \mathrm{N}$ latitude around the Earth.
Some of the air within the hot desert belt flows back toward the Equator in the lower troposphere forming the subtropical easterlies (fig. 3). The huge atmospheric cell created by flow from and back to the Equator is called the Hadley cell. Other air from the desert belt flows poleward, creating a wind system known as the westerlies. The warm westerlies eventually meet cold, dense, southward-moving polar air within a seasonally variable geographic band. As the air masses meet, the warm air rises and moves from west to east along a sinuous front, called the polar front or the westerly storm track (fig. 3). The polar front exists as interfingering masses of polar and westerly air. An advancing cold front occurs when polar air displaces westerly air, and an advancing warm front typically occurs as westerly air moves over polar air. The net upward motion of air along the polar front produces an upper tropospheric air flow towards the pole and the Equator. The atmospheric cell, defined by the westerlies at its base, is referred to as a Ferrel cell. At the pole, cold upper-atmospheric air sinks, forming dense, dry, cold air in the lower troposphere that flows equatorward, creating the arctic easterlies (fig. 3 ). The southern edge of the arctic easterlies rise as they approach the westerlies forming a series of polar low pressure cells. The air-mass boundary between the northern cold air and the westerlies is the polar front, which is where the polar jet-stream resides. The atmospheric cell defined by arctic and polar air is typically referred to as a Polar cell.

The strong contrasts in air pressure and temperature between the Hadley, Ferrel, and Polar cells produce a focused, high-velocity air stream at their upper atmospheric boundaries called a jet stream. The polar jet, which is the stronger of the two, resides between the Polar and Ferrel cells, whereas the subtropical jet resides between the Ferrel and Hadley cells.

The perpetual input of excess heat to the tropics maintains the circulation described above. The relative positions and strengths of air movement within the three cells changes seasonally as the Northern and Southern Hemispheres warm or cool. The Hadley and Arctic cells, along their northern and southern edges, respectively, have time averaged large, relatively stable and geographically limited air masses whose properties such as water-vapor content, temperature, and barometric pressure persist for most or all of the year. Some of these air masses are named and include 
the Aleutian Low, the Hawaiian High, and the Bermuda High.

Regional climate is further modified by factors such as topographic relief, proximity to oceans, and the mode of ocean heat transport, for example, the Gulf Stream. Changes within one cell, such as the movement of the equatorial Pacific warm pool that creates the ENSO phenomena, may impact weather in another cell. Hence, the El Niño component of ENSOs often produces wetter than average winters in southern Nevada (Winograd and others, 1998).

Regions within the Polar, Ferrel, and Hadley cells where air ascends are wet, whereas areas where air generally descends are dry. The tropical and subtropical rain forests lie within belts of rising air, just as does the northern boreal forest. Similarly, the polar and hot deserts lie in belts of descending air. On a smaller scale, air rising over a mountain and cooling creates precipitation, and air descending from a mountain and warming limits precipitation. For example, the Sierra Nevada mountain range lies within the westerlies, so the western slope is wet and the eastern slope is relatively dry, which creates the rainshadow over Yucca Mountain.

The present-day global circulation pattern is not fixed in time, but instead is simply a particular configuration in a continually changing climate system. Small changes in climate occur when the atmospheric heat budget is perturbed in some way. A change in solar output, for example, changes input in the tropics, and the entire circulation system adjusts. A reduction in solar output in the years from about A.D. 1400 to 1850 probably contributed to the Little Ice Age when the Arctic cell was strengthened and expanded, and shallow lakes appeared in the now dry Silver and Soda Basins in the Mojave Desert (Enzel and others, 1989). Similarly, a large volcanic eruption that ejects gas and particulates into the stratosphere (the layer of the atmosphere above the troposphere) also reduces solar input. Conversely, an increase in solar output may energize and expand the Hadley cell, although weakening and reducing the Polar cell. The Medieval Warm period (A.D. 950-1200) may be an example of that phenomena. Tree-ring data from southern Nevada indicate the region experienced drought during the Medieval Warm period (Graybill and others, 1994).

The arid to semiarid nature of present-day Yucca Mountain climate reflects both its location east of the Sierra Nevada Mountains and its location in the southern edge of the Ferrel cell. During the winter, the
Yucca Mountain region typically receives westerly flow, bringing maritime polar air into the region or, on occasion, it receives continental polar or even arctic flow as the polar front moves into the region. During the summer, the region typically receives flow from the south and west as the outflow from the desert belt intensifies and draws subtropical continental or maritime air into the region. The winter storms tend to be frontal in nature, whereas the summer storms are usually convective in nature. Modern-day hydrology in the Yucca Mountain region is a direct response to the current climate of the region.

\section{Past Climate-Nature of Climate Change}

Earth's orbital parameters relative to the Sun, including eccentricity, obliquity, and precession (Berger and Loutre, 1991) determine insolation. Change in insolation is highly predictable because it is related to well-established celestial mechanical phenomena, expressed in terms of these orbital parameters. Change in insolation from one millennium to the next is small, but over many millennia, the changes are significant and correlate with the waxing, and to a lesser extent, the waning of glacial periods (Berger and Loutre, 1991). Short-term climate-forcing functions, those operating over years to centuries, such as change in solar output, volcanic eruptions, and oceanic cycles (for example, ENSO), perturb the climate system, because they affect the atmospheric heat budget, as discussed above. Short-term climateforcing functions produce changes in the climatic system while operating within a generally constant insolation regime.

Eccentricity measures the shape of the Earth's orbit, which changes from a near-circle to an ellipse (fig. 4). When the orbit is circular, the tropics receive the same amount of heat in all months. Further, heat input to the Northern and Southern Hemispheres is seasonally symmetrical, that is, the Northern Hemisphere receives the same amount of heat in its seasons (for example, winter, December) as does the Southern Hemisphere in its equivalent season (for example, winter, June). When the orbit is elliptical, heat input to the tropics varies seasonally, and the heat input to the Northern and Southern Hemispheres is asymmetrical. The change from circular to elliptical orbits occurs over an approximately 100,000 -yr (100-ky), but 
successive cycles differ in magnitude, with four cycles forming a 400-ky cycle (fig. 4).

Obliquity is a measure of the Earth's tilt on its axis (fig. 4). The tilt of the Earth's axis changes from about 22 to $24.5^{\circ}$ over approximately a 44-ky cycle. A change in the Earth's axial tilt results in a change in the areal extent of the polar circle and, hence, the relative amount of heat received by the polar region during the year. Obliquity serves to increase or decrease the polar heat deficit relative to the tropics and, in this way, increases or decreases the strength of the Polar cell. The obliquity effect will be expanded or contracted as its periodicity moves in and out of phase with eccentricity.

Precession is a measure of the wobble of the Earth's tilt-axis during the Earth's orbit around the Sun (fig. 4). Today, the Earth's orbit is slightly elliptical, and the Earth is at its minimum distance from the Sun during the Northern Hemisphere winter but is tilted away from the Sun. Necessarily, the Southern Hemisphere is tilted towards the Sun when the Earth is at its minimum distance from the Sun. Thus, the Southern Hemisphere receives more insolation during its summer than does the Northern Hemisphere's summer, and the opposite would be true for the winters. However, because the Earth wobbles on its axis over a 12-ky period, the seasonal minimum and maximum distances to the Sun reverse for the Northern and Southern Hemispheres. So a full precession cycle is $24 \mathrm{ky}$ and is of major importance to the global heat budget. Eccentricity exercises a major influence over precession (fig. 4).

The orbital parameters eccentricity, obliquity, and precession operate on a millennial scale and variously add or subtract to insolation. Insolation at the Equator and in the Northern and Southern Hemispheres correlates with change in the climate system, as described in the section on modern climate. Change in insolation shows a positive correlation with climate change on a global scale. Climate change from glacial to interglacial modes has occurred throughout the last 2 million years (My), with the glacial modes existing about 80 percent of the time. During glacial climate modes, the Polar cell was much larger and supported a continental ice sheet in the Northern Hemisphere. The Ferrel cell was contracted and compressed between the Polar and Hadley cells, and probably the Hadley cell was weaker and reduced in size, lessening its influence over the Earth's heat budget.

Because insolation is calculated from known principles of celestial mechanics, future values of insolation may be determined (fig. 4). The Earth presently falls within the eccentricity 400-ky cycle where, during the next 100-ky subcycle, Earth orbit will describe a relatively circular rather than elliptical orbit. The last time that occurred was $400 \mathrm{ky}$ ago and, as shown in figure 4, insolation for the next $100 \mathrm{ky}$ will be quite similar to that between 400 and $300 \mathrm{ka}$.

Glacial climate in the Yucca Mountain region was and will be significantly different than the present climate. During a glacial period, the polar front would reside in Nevada year-round and would frequently move south of Yucca Mountain. Therefore, westerly flow with its maritime polar air could occur throughout the year and might dominate the summers, whereas continental polar and arctic air incursions also could occur throughout the year and might dominate the winters. Modern summer circulation patterns with flow from the south likely would not exist during glacial periods due in part to the weakened or fragmented character of the Hadley cell. Glacial climates bring a circulation mode more like that of southern Canada into the southern Nevada region, although due to the Sierra Nevada Mountains and probably to lower specific humidity as a consequence of cooler oceans, precipitation patterns would likely differ from those in Canada.

This somewhat hypothetical discussion of climate change correlated with change in insolation can be shown to apply to the Yucca Mountain region based on the results of studies of long climate records. Such records provide information about how lakes have changed with time and how those changes, when dated, can be compared with insolation curves to establish a correlation. Similarly, the well-dated Devils Hole record of stable isotope changes within the regional carbonate aquifer during the last $500 \mathrm{ky}$ provides a key linkage of regional climate to insolation.

\section{Long Climate Records}

\section{Devils Hole}

The walls of Devils Hole, a saturated open fracture in the regional Paleozoic-aquifer discharge area $90 \mathrm{~km}$ south of Yucca Mountain, are lined with calcite precipitated from the water. Winograd and others (1992) took a 36-cm core from the vein calcite, acquiring an isotopic record of climate change extending from beyond $500 \mathrm{ka}$ to about $60 \mathrm{ka}$. A chro- 
nology for the vein-calcite record comes from numerous $\mathrm{U} / \mathrm{Th}$ and $\mathrm{U} / \mathrm{U}$ dates, making it the bestdated climate record for the past $500 \mathrm{ky}$.

The stable isotopic climate signal principally comes from $\delta^{18} \mathrm{O}$ values that reflect isotopic variations in the source and temperature of precipitation falling as snow or rain in recharge areas, especially the Spring Mountains (Winograd and others, 1988, 1992). The $\delta^{18} \mathrm{O}$ values of water vapor arriving in the recharge areas, ultimately from oceanic areas, is a function of factors such as oceanic source area, oceanic surfacewater temperature, temperature and humidity of the air over the ocean, windiness, and the vapor path to the recharge area (Winograd and others, 1992; Grootes, 1993). The $\delta^{18} \mathrm{O}$ values of precipitation in the recharge area reflect factors such as air temperature and rate of precipitation (Winograd and others, 1992; Benson and Klieforth, 1989). Although the factors affecting the isotopic values from the Devils Hole vein calcite are numerous and complex, they probably vary in tandem.

The dated Devils Hole $\delta^{18} \mathrm{O}^{1}$ record shows the major glacial and interglacial cycles also known from the marine $\delta^{18} \mathrm{O}$ records and from $\delta^{18} \mathrm{O}$ records from ice cores (fig. 5). The marine isotopic record was dated by fitting an integrated composite record derived from the isotopic profiles from several cores with the orbital insolation record and its chronology (Imbrie and others, 1984). This composite record is called SPECMAP, for the Spectral Mapping Project that produced it (Imbrie and others, 1984). Low-insolation periods in the northern hemisphere coincide with a marine isotopic record of glaciation, whereas high

\footnotetext{
${ }^{1}$ Stable isotopic compositions are typically reported in delta ( $\delta$ ) notation as the per mil deviation of the ratio of the heavy to light isotopes (deuterium to hydrogen, ${ }^{18} \mathrm{O} /{ }^{16} \mathrm{O},{ }^{13} \mathrm{C} /{ }^{12} \mathrm{C}$ ) in the sample to that of a reporting standard. The relation is defined as follows:
}

$\delta($ per mil $)=\left[\left(R_{\text {sample }}-R_{\text {standard }}\right) / R_{\text {standard }}\right] \times 1000$

A similar relation can be used with radiogenic ${ }^{87} \mathrm{Sr} /{ }^{86} \mathrm{Sr}$ values. Internationally accepted reference standards are Standard Mean Ocean Water (SMOW) as analyzed by the International Atomic Energy Agency (IAEA) in Vienna (VSMOW) for D/H and ${ }^{18} \mathrm{O} /{ }^{16} \mathrm{O}$, belemnite shell carbonate from the Pee Dee Formation of North Carolina (VPDB) as determined by IAEA for ${ }^{13} \mathrm{C} /{ }^{12} \mathrm{C}$, and dissolved strontium in modern sea water for ${ }^{87} \mathrm{Sr} /{ }^{86} \mathrm{Sr}$. By definition, the references standards have $\delta=0$ per mil. Heavy-isotope enriched or depleted materials have positive or negative $\delta$ values, respectively. insolation in the northern hemisphere coincides with interglacial intervals. The similarity in the timing for the initiation of glaciation on the Devils Hole, SPECMAP, and Vostok ice core data indicates a common cause for global climate change and, thus, climate changes in southern Nevada synchronously with global change, at least on a relative basis.

The timing of key climate events such as the terminations of various glacial periods differ between Devils Hole and the SPECMAP composite record. The Devils Hole isotopic record is independently dated; that is, it does not depend on the assumption of insolation forcing of climate change to date the record. The Devils Hole record shows that, whereas glacials begin according to an orbital clock, they often end much sooner. The differences between the Devils Hole ages and those of SPECMAP imply that millennial-scale climate change is not a simple function of insolation forcing. Comparison of the timing for the beginning of glaciation in the northern and southern hemisphere (fig. 5) shows they are the same even though an insolation minimum in the northern hemisphere must be balanced by an insolation maxima in the southern hemisphere. Consequently, insolation per se cannot be the sole driver of climate change from an interglacial to a glacial period. Discussion above on modern climate and past climate identified many Earth-based forcing functions that play a role in climate change. Indeed, there also are long-term Earth-based forcing functions such as continental drift that also play a role in the nature of climate. A discrepancy of a few thousand years between actual dates and those from the assumption of orbital timing should not be surprising and although important for eventually understanding the causation of major climate change are not a problem for the issues here. In the case of the Devils Hole record, the glacial intervals appear in step with an orbital clock and disappear in or out of step depending on the particular glaciation.

\section{Owens Lake}

The Owens River system (fig. 1), with its sequence of downstream basins (Owens, China, Searles, Panamint, and Death Valley), forms a comparatively simple network where the upstream lakes must spill before the lakes lower in the chain receive sufficient water to freshen (Smith, 1976). The U.S. Geological Survey Global Change and Climate History Program took three cores from the southcentral part of Owens Lake playa, Inyo County, Cali- 


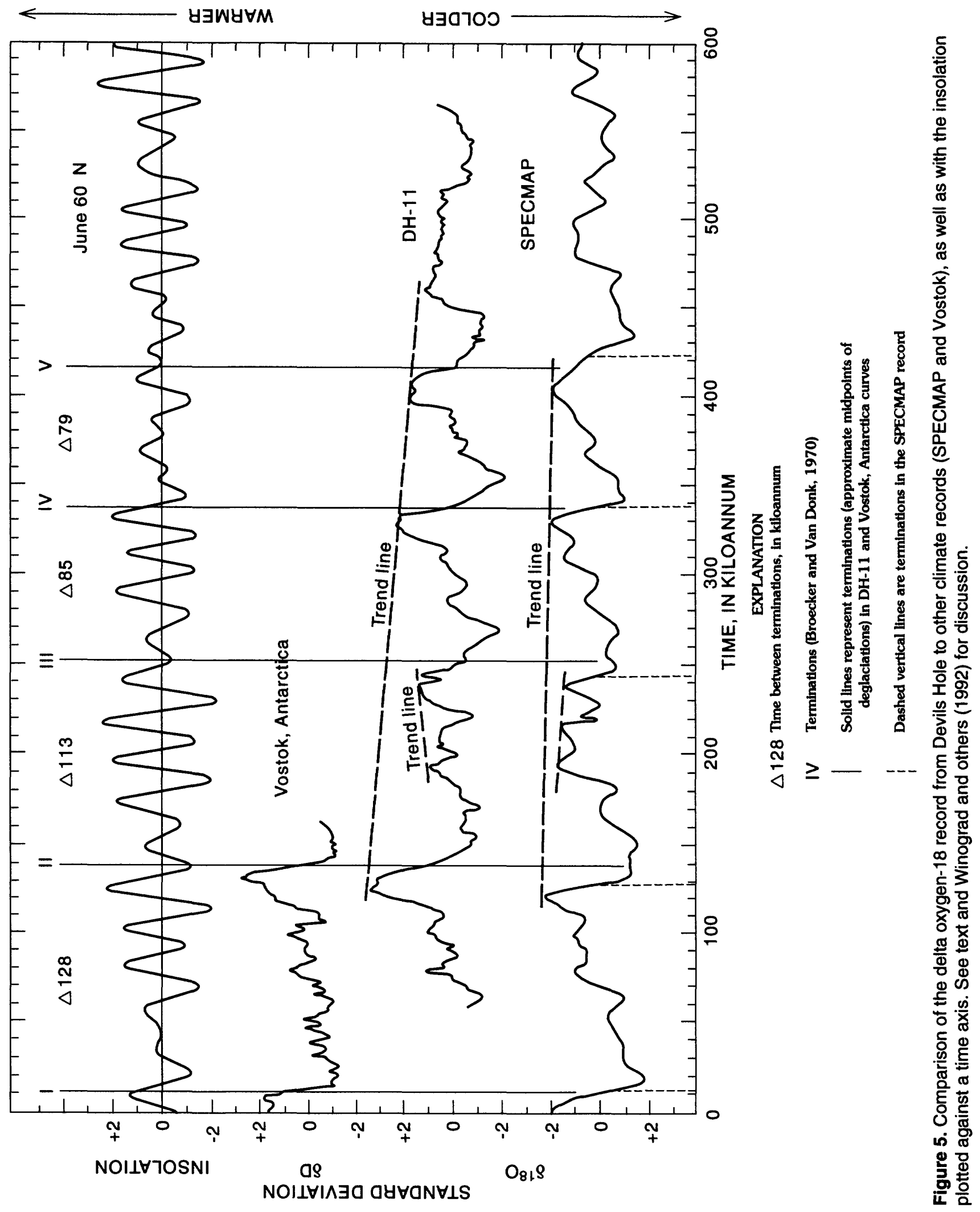


fornia (fig. 1), in the spring of 1992 with a rotary, truck-mounted coring rig (Smith, 1993). The composite core (OL-92) represents 80 percent of the section and provided the lake-sediment record used in this report. The cored record of Owens Lake spans the past $850 \mathrm{ky}$. Because our interests are in climate of the last insolation cycle ( $400 \mathrm{ky}$ ), the discussion below will focus on just the past $500 \mathrm{ky}$.

\section{Climate and Hydrologic Setting}

Owens Lake (playa floor elevation $=1080 \mathrm{~m}$, area $=182 \mathrm{~km}^{2}$ ) lies in a graben immediately east of the highest part of the Sierra Nevada mountains (Mt. Whitney, $4418 \mathrm{~m}$ ). Snowmelt from the Sierras and, to a lesser extent the Inyo and White Mountains, provides the major source of surface water for the Owens River (Smith and Street-Perrot, 1983) and for recharge (Hollett and others, 1991). Today and probably in the past, snowpack ultimately is related to the strength and persistence of the westerlies aligned with the polar jet stream, which serves to direct storms laden with Pacific moisture toward the cordillera. Today, rain comprises a secondary source of water for the Owens River. Rain maxima occur in the Owens drainage during April and August (Pyke, 1972). Significant late-summer and fall storms typically originate from tropical cyclones that bring moisture to the Great Basin from the subtropical oceans (Hansen and others, 1981; Kay, 1982). Although the frequency and magnitude of such storms vary, they do supply water to a significant ( $\sim 80$ percent) part of the Owens Lake drainage basin located outside the Sierra Nevada. Inspection of precipitation data from the Owens Lake area indicate that wet summers do not result in the high levels of precipitation becoming flow, presumably due to evapotranspiration. Such precipitation on and east of Owens Lake could have a significant impact on Owens limnology during past climates however.

During the mid- to late 19th century, natural flow from the Owens River maintained a lake that was alkaline and about $15 \mathrm{~m}$ deep. Between 1872 and 1905 , flow was reduced to about 25 percent of its natural level due to irrigation in the Owens Valley (Gale, 1914). Even so, the inflow was sufficient to maintain a perennial, if saline, lake about $6 \mathrm{~m}$ deep. The construction of the Los Angeles Aqueduct in 1913 diverted the lake's principal source of water, and the lake soon desiccated in a climate with an evaporation rate of about $1.65 \mathrm{~m} / \mathrm{yr}$ (Smith, 1976). Locally, alka- line springs discharge along the margin of the lake basin. For Owens Lake to spill today, it would have to be about $65 \mathrm{~m}$ deep with an area of $690 \mathrm{~km}^{2}$.

\section{Climate Linkage to Owens Lake Chemistry and Paleontology}

The major dissolved-ion (solute) composition of high-elevation waters from the Sierra Nevada, Inyo, and White Mountains throughout the Owens Lake drainage is dominated by solutes rich in calcium and bicarbonate and contains moderate to low concentrations of sulfate $\left(\mathrm{SO}_{4}\right)$. The total alkalinity (largely bicarbonate)-to-calcium (meq/L) ratio is usually less than 2. Sodium, magnesium, and chloride $\left(\mathrm{Na}^{2+}\right.$, $\left.\mathrm{Mg}^{2+}, \mathrm{Cl}^{-}\right)$are present in low concentrations relative to the other major ions, except in the Inyo and White Mountain drainage area, which have higher $\mathrm{Mg}$ concentrations derived from dolomite dissolution. The total dissolved-ion concentration (TDS) of the highelevation waters is low, usually less than $100 \mathrm{mg} / \mathrm{L}$.

The solute composition of valley-floor waters, largely derived from springs, is very different from those at high elevation. The low-elevation waters are dominated by sodium-bicarbonate and chloride, $\mathrm{SO}_{4}$ is variable, and calcium $\left(\mathrm{Ca}^{2+}\right)$ and magnesium $\left(\mathrm{mg}^{2+}\right)$ are at low concentrations. The alkalinity to calcium ratio is large, commonly much greater than 2 , and the TDS is moderate to high, often above $500 \mathrm{mg} / \mathrm{L}$.

Given the initial alkalinity-to-calcium ratio of the dilute high-elevation waters, their solute composition will evolve towards carbonate-depleted and calcium-enriched waters or a solute composition low in both ions (Eugster and Jones, 1979). The higherTDS waters at low elevation have exactly the opposite relation between bicarbonate and calcium; bicarbonate is enriched and calcium is depleted. Thus, the solute composition of the low-elevation waters must be derived from a process other than evaporation of the high-elevation waters.

Solute compositions dominated by sodium, bicarbonate, and chloride are typical products of water-fine grained volcanic rock interactions. Spring discharge at low elevation contains solutes dominated by sodium, bicarbonate, and chloride, at moderate to high TDS, and often at elevated temperatures. These waters are derived from the interaction of basin ground waters with reactive fine grained volcanic rocks. Although the primary sources of water for the Owens River apparently come from high elevation, the solute 
composition of the river at low elevation is characterized by spring and other ground-water discharge rather than evaporation of the dilute high-elevation waters.

In broad terms, the fossil diatoms and ostracodes in the Owens Lake long core reflect the waterchemistry spectrum found in the Owens River drainage. The calcium-bicarbonate-rich waters are characterized by freshwater planktic diatoms such as Stephanodiscus, which indicate large, deep freshwater lakes (Fritz and others, 1993), or ostracodes such as Cytherissa lacustris, which live in dilute cold lakes commonly found in the boreal forest (Delorme, 1970). The sodium-bicarbonate-rich aquatic environments also have specific, high-conductivity, shallow-water diatoms such as Campylodiscus clypeus (Fritz and others, 1993) and ostracode taxa such as Limnocythere sappaensis (Forester, 1983, 1986).

The microfossil record can be translated into a chronological progression of climate-induced hydrochemical environments. Microfossils of fresh, calcium-bicarbonate-rich water indicate cool, wet climates when the Owens River was dominated by discharge from high-elevation watersheds, whereas fossils of shallow, sodium-bicarbonate-rich water indicate dry climates with reduced mountain flow and greater relative importance of low-elevation spring discharge into Owens Lake. This contrast will be referred to herein as the Owens Lake climate/hydrology relation.

Although this climate/water chemistry linkage identifies relative climate states, it does not yet allow for direct interpretation of MAP or ranges of MAP. The linkage of water chemistry and microfossils to values of MAP is being developed with simple models based on present relations between MAP, water and solute flux, and on relations of microfossils from the last glacial cycle to MAP by means of woodrat midden data from the basin.

\section{Core Stratigraphy}

\section{Lithostratigraphy}

The upper $225 \mathrm{~m}$ of core OL -92 consists predominantly of lacustrine silt and clay interspersed with several thin beds of sand. Some silty units contain up to 40 percent by weight calcium carbonate that reflects large abundance of ostracodes, calcareous algae, and/or authigenic calcite. Much of the silt-sized fraction represents the shells of diatoms and angular silt-sized rock fragments derived from glacial flour. The clay fraction varies between smectite and illite (Menking and others, 1993). About 70 percent of the clastic sedimentary units are massive, some clearly because of bioturbation. Other units are thinly bedded. Sand pods and granules (ice-rafted?), thin tephra beds, and possible turbidity-current structures also are present (Smith, 1993).

\section{Chronostratigraphy}

The paleomagnetic record of core OL-92-2 (Glen and others, 1993) places the Matuyama/ Brunhes magnetostratigraphic boundary $(783 \mathrm{ka})$ at $311.3 \mathrm{~m}$. The Bishop ash (760 ka) at $309.15 \mathrm{~m}$, the Dibekulewe ash (510 ka) at $224.15 \mathrm{~m}$ (Sarna-Wojcicki and others, 1993), and radiocarbon dates in the upper $23 \mathrm{~m}$ of core OL-92 provide a chronologic framework for the deposits. The base of the core is estimated to represent the period about $850 \mathrm{ka}$. According to these data, the composite core has a dry bulk sedimentation rate of approximately $40 \mathrm{~cm} / \mathrm{ky}$ (Bischoff, 1993). The age model based on calculated mass-accumulation rates is believed to be reasonably, but not perfectly accurate. As discussed below, examination of the diatom and ostracode paleoenvironmental stratigraphic sequence shows a regular sequence of interglacial and glacial events. The ages of those events, based on the age model, variously agree or disagree with the Devils Hole Chronology. We believe disagreement of the age model with the Devils Hole chronology simply reflects error in the Owens Lake age model.

\section{Owens Lake Diatom Record}

\section{Diatom Analysis}

\section{Methods}

Samples for diatom analysis of about $1-\mathrm{cm}$ stratigraphic thickness were removed from the split core with a clean spatula and stored in airtight plastic bags. The sediments were processed for diatoms by hot acid digestion, and the cleaned residue was settled on coverslips and mounted in Hyrax (Bradbury, 1993). 


\section{Paleohydrologic History of Owens Lake- The Diatom Record}

Abundant, loosely attached diatoms (species of "Fragilaria") along with planktic species are common from about 500 to $400 \mathrm{ka}$. The Fragilaria-dominated assemblages indicate that Owens Lake was shallow and characterized variously by open water to a through-flowing marsh during this time. Marsh environments probably indicate climates of intermediate moisture and a shallow basin filled by sediment.

Major episodes of freshwater diatoms occur at $470-430 \mathrm{ka}, 400-330 \mathrm{ka}, 260-220 \mathrm{ka}, 170-120 \mathrm{ka}$, $70-60 \mathrm{ka}$, and $50-10 \mathrm{ka}$ (fig. 6). In most cases, these intervals indicating cool, wet climates are separated by intervals rich in saline diatoms or intervals with sediments barren of diatoms, which imply shallow, alkaline water conditions. Thus, the diatoms define the long-term climate/hydrological behavior of the Owens River system. The potential rapidity of climate change is illustrated by prominent spikes of freshwater planktic diatoms such as the one between 72 and $65 \mathrm{ka}$ that interrupts the declining trend of saline benthic diatoms (fig. 6).

Overall, the stratigraphic continuity of freshwater diatoms from Owens Lake indicates a record of a longer-lasting and more persistent fresh and overflowing lake system than that of a shallow, saline system. The concentration of freshwater diatoms, in direct contrast to the ostracodes, is generally an order of magnitude greater than concentrations of saline diatoms, partly reflecting poor diatom preservation in saline systems. Therefore, rare and short-lived episodes of high concentrations of saline planktic diatoms, implying large and possibly deep saline lakes, may be underrepresented in the Owens Lake record and contrast with the paleolimnology of internally draining Great Basin lakes such as Walker Lake (Bradbury and others, 1989).

Over the past 500 ky, Owens Lake has been fresh (implying climates wetter than today) for about 80 percent of the time and saline (implying climates like today) only about 20 percent of the time. Although there is some variation, intervals of wet climate (freshwater conditions) average about $32 \mathrm{ky}$ in length, whereas dry climates (saline conditions) average about $13 \mathrm{ky}$.

\section{Owens Lake Ostracode Record}

\section{Ostracode Methods}

The climate interpretations derived from the ostracodes found in the Owens Lake cores are based on 672 samples covering the past $400 \mathrm{ky}$. About 75 percent of those core samples contained sufficient ostracodes for environmental interpretations. Each sample covers about a 5-cm-thick stratigraphic interval, and a sample was taken every $20 \mathrm{~cm}$ in core from the upper $200 \mathrm{ky}$ and every $33 \mathrm{~cm}$ from material below $200 \mathrm{ky}$. The valves were extracted from the sediments and the adults identified and counted. The data set discussed below is based on a total count of 145,000 valves.

\section{Paleolimnological History of Owens Lake- The Ostracode Record}

The stratigraphic profile (fig. 7) of the ostracodes found in the Owens Lake record shows how the lake's hydrochemistry has changed during the last $400 \mathrm{ky}$. The ostracodes are arranged in the diagram according to hydrochemical tolerances. Limnocythere sappaensis, on the right side of the graph (fig. 7), lives in the springs that discharge onto the lake floor today, such as those near Keeler on the northeastern side of the lake and at Dirty Socks Spring on the southern side of the lake. Thus, $L$. sappaensis marks modern-like periods when flow from high elevation was minimal and flow plus solute input from low elevation was maximal. Cytherissa lacustris, on the left of the graph (fig. 7), represents limnological and climatic periods least like those of today. It implies the presence of a large, deep, seasonally stable, cold, dilute freshwater lake dominated by source waters from high elevations. Candona caudata and Limnocythere c.f. L. friabilis may live in the same environments as C.lacustris, as well as in smaller lakes at higher TDS and temperatures (Bradbury and others, 1989). Presence of L. c.f. L. friabilis implies continued dominance by waters from high elevation (Forester and others, 1994) but at times, when C. lacustris is absent, with less flow. The taxa in the center of the graph (fig. 7), such as Limnocythere ceriotuberosa, identify periods when the lake was supported by a mixture of high- and low-elevation source waters (Forester, 1986). They further indicate the existence of a seasonal lake variable in size, depth, TDS, and temperature. The source water during these 


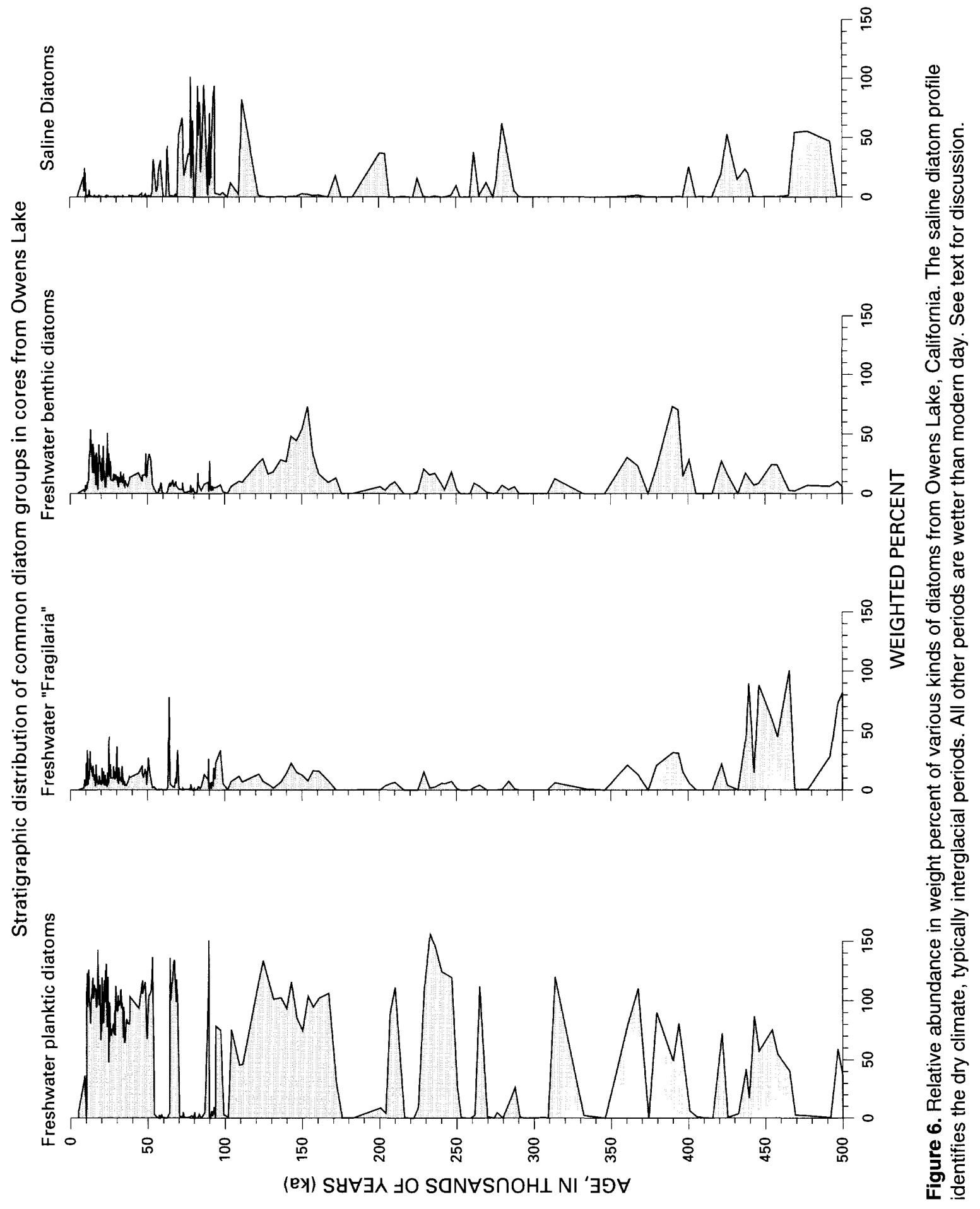




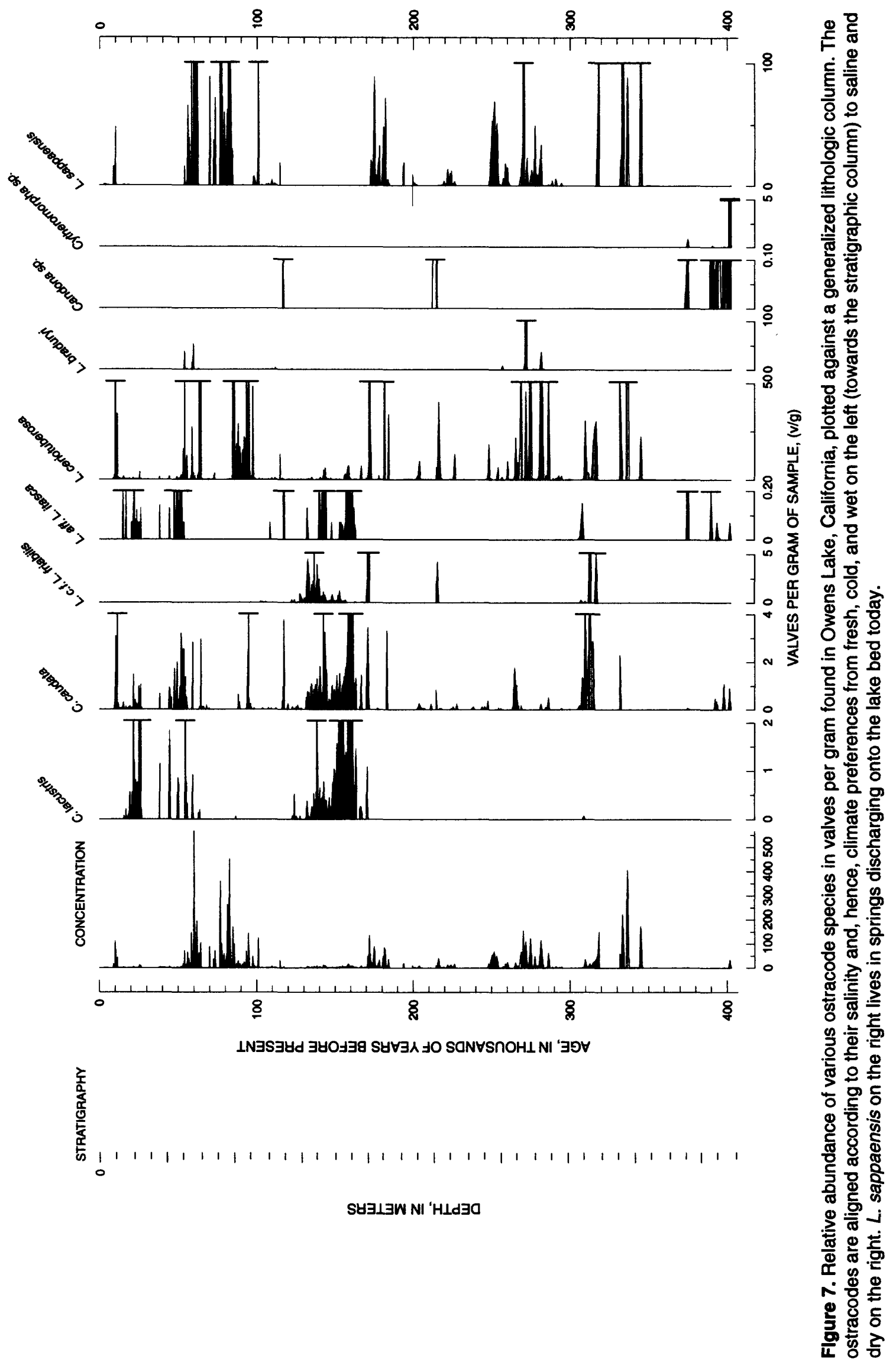


periods was dominated by discharge from springs and base flow in the Owens River.

Like the diatoms, the ostracode profiles indicate that through much of the last 400-ky cycle, climate was wetter than today. Limnocythere sappaensis represents about 20 percent of the samples. Because $L$. sappaensis lives only in very alkaline waters where calcite is readily preserved, this should be a good estimate of the duration of modern-like climate/hydrological environments. Because $L$. sappaensis reflects the driest environment in the record, 80 percent of the samples indicate wetter climates than today, although that estimate would include samples barren of ostracodes (140), and assumes that barren samples result from ostracode calcite dissolving in dilute freshwater.

Cytherissa lacustris represents the extreme cold and/or wet phases in the ostracode record. It occupies about 5 percent of the samples and occurs almost exclusively from about 170 to $130 \mathrm{ka}$ and from about $60 \mathrm{ka}$ sporadically to $18 \mathrm{ka}$ (fig. 7). Similarly, Candona caudata and Limnocythere c.f. L. friabilis distributions are characteristic of the upper half of the Owens Lake record. The absence of $C$. lacustris in sediments from about $400 \mathrm{ka}$ to $170 \mathrm{ka}$ indicates "warmer" glacial periods than existed during the last two glacial periods. Thus, the ostracode climate/ hydrological record of Owens Lake indicates the four 100 -ky climate subcycles are not climatically identical to one another.

The ostracode record also shows how rapidly climate changes in this region. Change from modernlike Limnocythere sappaensis periods to wetter periods typically occurred in hundreds, not thousands, of years. Such rapid changes from warm/dry to cold/wet climates indicate a southerly shift in the average position and strengthening of the westerly/polar front associated with the polar jet stream.

\section{Correlation of Owens Lake Paleolimnology and Oxygen Isotope Records}

The Owens Lake chronology is based entirely on a sediment accumulation rate age model (Bischoff and others, 1993). The age of a particular sample, as derived from the age model, could be older or younger than the actual age of the sample. Because the rate of sediment accumulation may be expected to change in a lake basin, the calculated versus real ages may converge at some depths and diverge at others. However, the derived, extrapolated chronology appears to explain the major paleolimnologic fluctuations of the Owens Lake record in a manner generally consistent with well-dated changes in the Devils Hole record. When the climate proxy record (discussed below) is examined in stratigraphic order, one finds long intervals that can be attributed to glacial periods and shorter intervals that can be attributed to interglacial periods. When the age estimates from the Owens Lake age model for the glacial and interglacial periods are compared to the Devils Hole chronology, the agreement varies in the timing of those events from good to poor. Both records, however, appear to have the same sequence of glacial and interglacial events. Consequently, just as the undated marine record was tuned to an orbital time scale, the Owens record could be tuned to the Devils Hole or SPECMAP records.

A good correlation exists, after considering the above paragraph, between the diatom and ostracode Owens Lake climate/hydrological records, SPECMAP, and the Devils Hole record of global climate change known as Oxygen Isotope Stages (OIS) (figs. 8 and 9). The diatom record (fig. 8), indicating large freshwater lakes, shows prominent intervals at 470-430 ka (OIS 12), 400-310 ka (OIS 10), 250-220 ka (OIS 8 falls between 280 and $250 \mathrm{ka}$ ), $170-110^{2} \mathrm{ka}$ (OIS 6), 72-65 ka (OIS 4), and generally after $50 \mathrm{ka}$ (OIS $3+2)$ until the Holocene ( $<10 \mathrm{ka}$, OIS 1). The discrepancy between the diatom record and OIS 8 probably indicates a problem with the Owens Lake age model.

The ostracode record (fig. 9) shows a pattern similar to that of the diatoms, but owing to the preservational differences, the ostracode record offers a better indication of the interglacial periods and transitions to glacial periods than of the glacial intervals. The ostracode record from 400 ka shows a transition into OIS 10; then a barren interval; followed by saline conditions from about 350 to $320 \mathrm{ka}$ (OIS 9); then a mix of fresh, intermediate, and saline waters, 300 to $220 \mathrm{ka}$ (OIS 8); then saline conditions from 200 to $180 \mathrm{ka}$ (OIS 7); saline from about 115 to $95 \mathrm{ka}$ (middle of OIS 5); then saline again from 85 to $70 \mathrm{ka}$ (end of OIS 5); saline again from 60 to $50 \mathrm{ka}$ (part of OIS 3); and, finally, saline conditions from 10 to $0 \mathrm{ka}$ (OIS 1). The ostracodes also identify prominent wet periods from 170 to $140 \mathrm{ka}$ (OIS 6) and sporadically from about 55 to $40 \mathrm{ka}$ (part of OIS 3) and from about 25 to $18 \mathrm{ka}$ (OIS 2).

Significantly for this project, the ostracode data imply that the first two glacial periods in the past 
400-ky cycle were not as cold as were the last two glacial periods in that cycle. Cold air-temperatures greatly reduce evaporation and, hence, raise effective moisture even when MAP is low. Applying the assumption that the future climate might be more like the climate from an earlier rather than the last two glacial periods would mean less effective moisture because, although higher MAP would be needed to fill Owens Lake than during cold periods, evaporation throughout the region would remain high. The hypoth- esis, that the future will be milder than the past, requires verification.

Some correlations of the ostracode climate/hydrological record with SPECMAP are better than others. For example, OIS 8 shows a poor correspondence that probably indicates an age-assignment problem. Similarly, OIS 5 begins with microfossils, such as Candona caudata, indicative of cool, wet conditions, and not until $115 \mathrm{ka}$ do the ostracodes shift to indicators of warm and, perhaps, wet climates.

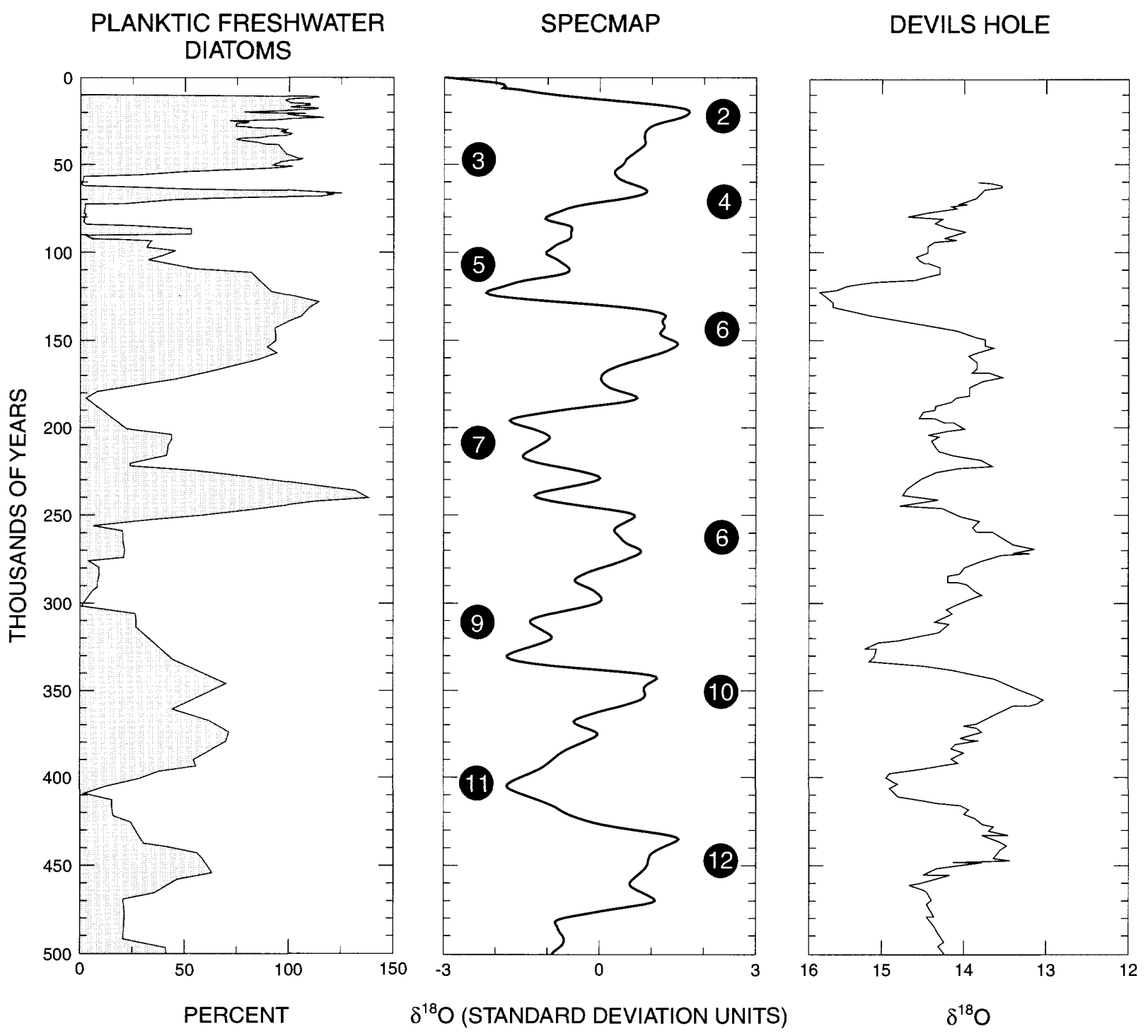

Figure 8. The freshwater planktic diatom stratigraphic distribution from Owens Lake compared to the SPECMAP and Devils Hole records. Even numbers in circles next to SPECMAP profile identify the widely recognized stable isotope glacial periods recognized from oceanographic records, and the odd numbers identify the interglacial periods. Each number refers to a particular oxygen isotope stage (OIS). 


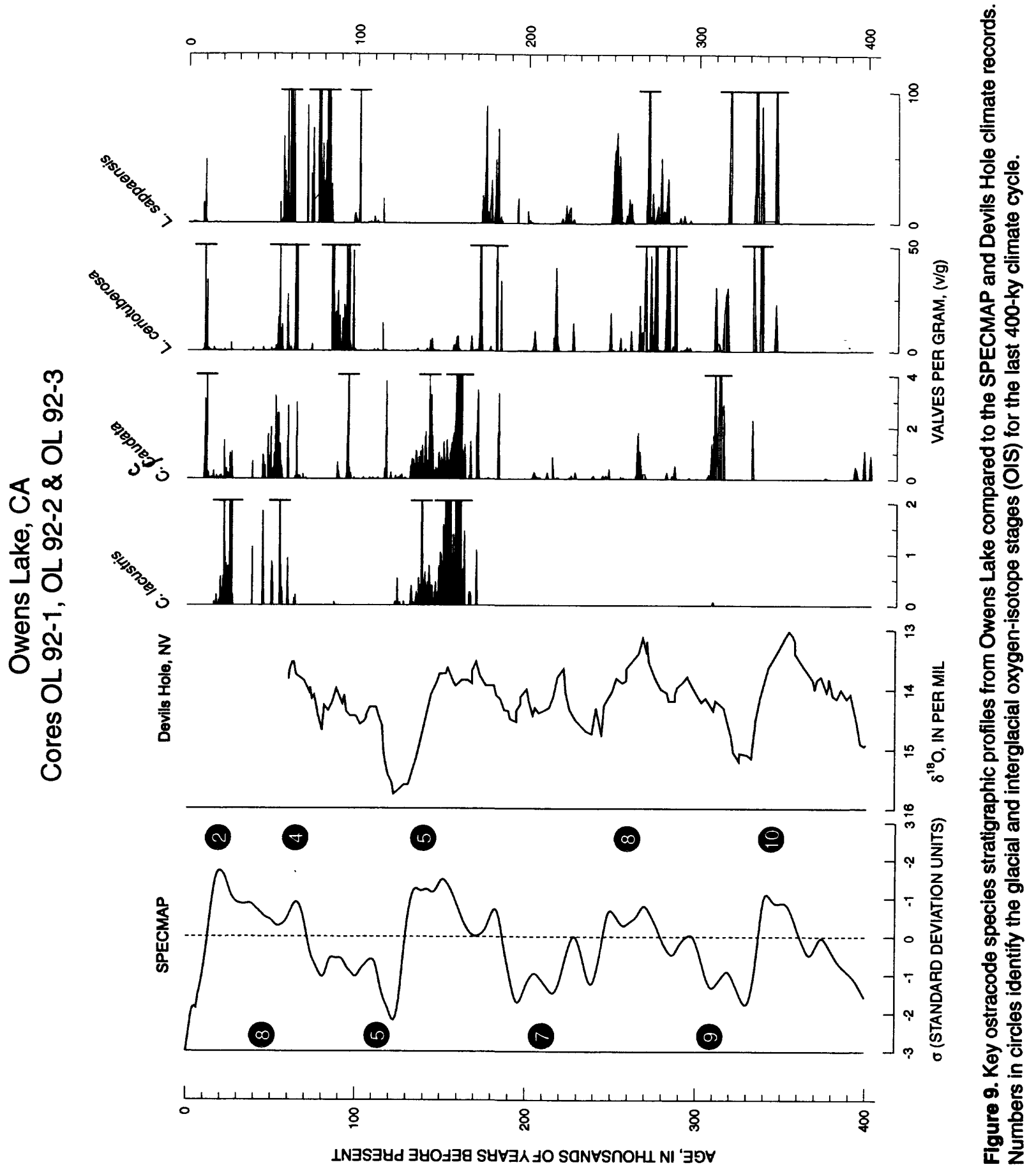


Oxygen Isotope Stage 5 is a long and complex interglacial interval, and the climate/hydrological record from Owens Lake may reflect this complexity. The good correspondence, however, between the Owens Lake record to OIS 10,6 , and 2 implies reasonable age estimates during those intervals. The correlation of the Owens Lake climate/hydrology record to either SPECMAP or to Devils Hole is not perfect, just like the correlation between SPECMAP and Devils Hole records. Nonetheless, the Owens Lake record clearly shows the general progression of glacial and interglacial periods known from the SPECMAP and Devils Hole records and clearly illustrates substantial climate change in the region, as well as the persistence through the past of climates that were wetter than modern.

\section{Other Data Sets}

A number of other data sets also were collected from for parts of the Owens Lake cores. These data sets include pollen, carbonate mineralogy, paleomagnetic susceptibility, and sediment mineralogy. Microfossil records also exist from other lakes in the region. The sedimentological data sets from Owens Lake support the climate/hydrological interpretations from the microfossils. Data sets from other lakes in the region add a spatial aspect to the Owens Lake records that allows the climate interpretations from Owens Lake to be tested against other records from the same period of time.

\section{Conclusions}

1. The Owens Lake record is coupled to climate through the relative quantities of water and solutes delivered to the lake during different climate modes. The microfossil record from Owens Lake serves as a proxy for the climate/hydrological couplet and shows that, during the past $400 \mathrm{ky}$, climate was wetter than modern about 80 percent of the time.

2. The wet periods coincide with the long, complex glacial climates. Most of those glacial climate periods correlate with the SPECMAP and Devils Hole records of global climate change and thereby indicate that future climate change may occur on a schedule that is related to the changes in the Earth's astronomically based insolation cycle.

3. The Owens Lake record indicates that climate during the various glacial periods was not uniform and further indicates that during the past $400 \mathrm{ky}$, glacial periods occurred during OIS 6 and OIS 2. Presuming this relation can be verified for all proxies and by showing climate is recorded in the same way throughout the 400-ky cycle, then assuming climate is cyclic, and the cycle is starting over, the next glacial interval will probably have a climate that is milder but probably wetter than the last two.

4. The timing for the transition toward the next glacial period will be roughly equivalent to the timing of the transition from OIS 11 to OIS 10 plus $400 \mathrm{ky}$. That indicates we are near transition now.

\section{Lakes, Playas, and Marshes}

\section{Introduction}

The present southern Nevada climate exhibits an enormous precipitation deficit. Effective moisture (MAP minus mean annual evapotranspiration) from one estimate has a deficit of more than $1,000 \mathrm{~mm}$ (Winter and Woo, 1990). As a consequence, marshes and wetlands common to northern Nevada valleys are rare in southern Nevada. The Pahranagat marshes are the nearest wetlands to Yucca Mountain. Most surface water in the Yucca Mountain region is either runoff or spring discharge.

During the last and earlier glacial cycles, higher effective moisture supported higher water tables and increased runoff in most southern Nevadan valleys. Quade and others (1995) identified the deposits from these former wetlands and interpreted the environments associated with them. A variety of fossils, including mammals, molluscs, ostracodes, pollen, impressions of leaves from trees and shrubs, and diatoms have been identified from the paleowetland sediments. Mammal remains range from meadow mice of marsh environments to mammoths, reflecting the diverse terrestrial communities supported by past climates in southern Nevada.

Deposits from the Las Vegas, Indian Springs, and Pahrump Valleys, as well as Crater Flat, Lathrop Wells, and the Amargosa Valley have been studied during Yucca Mountain project site characterization activities and collected for fossils. The sites along the Yucca Mountain ground-water flow gradient are discussed in the section on past discharge and will not be treated in this section. 
Sites from the Pahrump Valley, such as the Hidden Valley or the Stump Spring sections, contain paleoclimatic and paleohydrological information, but past aquatic environments at those sites also may reflect fault control of the hydrology (Quade and others, 1995) so the water table does not rise uniformly along the valley bottom. Discussion of those sites awaits the distinction of the climate/hydrological signal from tectonic overprints, which could affect flow properties and, hence, the climate signal. The records from the Las Vegas and Indian Springs Valleys contain good climate and hydrological information based on sediment stratigraphy and fossils. Fossil data from one of those sections, $\mathrm{OCI}-11$, are discussed below, as its environmental information is representative of the other sections.

\section{Corn Creek Flat (Maln) Section OCL11}

Section OCI-11 (fig. 10) lies near the center of the Las Vegas Valley (figs. 1, 2D). The informal stratigraphic units denoted B, D, and E were described by Quade (1986). These units are distinguished from each other by a variety of sedimentary features such as bed forms, grain size, color, rhizolith (rhizolith $=$ rootstone = carbonate or opal cemented sediment coatings formed when root decomposes?) content, and fossils (Quade, 1986; Quade and Pratt, 1989; Quade and others, 1995). Units B and D occur throughout the Las Vegas Valley, indicating extensive wetlands.

Twenty-two radiocarbon dates constrain the age of these sediments. Radiocarbon dates from unit B imply it is older than the limit of radiocarbon detection, about $40 \mathrm{ky}$. The unit B ostracode assemblage indicates a cool and wet climate, perhaps correlating to the penultimate glacial period (170 to $140 \mathrm{ka})$ or the early part of the middle Wisconsin interval (70 to $60 \mathrm{ka}$; see, for example, the Owens Lake climate record). Conversely, unit $D$ radiocarbon dates show it was deposited during the last glacial cycle. Similarly, dates on unit $E$ indicate deposition at the end of the last glacial cycle during the climate transition to the Holocene.

The abundant ostracodes (fig. 10) and molluscs in unit B indicate this environment was a shallow, relatively freshwater, typically permanent wetland supported by the regional water table and flowing springs. Climate parameters, as yet, have not been generated from the ostracodes in unit B. Nonetheless, the persistence of a fresh, permanent wetland on the Las Vegas Valley floor where modern effective mois- ture deficits are more than $1,000 \mathrm{~mm}$ requires a substantial shift in some combination of increased MAP and decreased MAT.

The ostracode taxa from unit $\mathrm{D}$ also indicate a wetland spring complex similar to the assemblages from unit B (fig. 10). Unit D species imply this wetland had a higher flow component than did unit B. Further, the smaller quantity of aquifer species in unit $D$ may indicate less discharge from the regional aquifer. Forester and Smith (1994) estimated MAP based on ostracodes from a nearby section (LPM-34, fig. 2D). They indicated MAP was four to five times higher than today. However, they did not recognize the importance of flow through the wetlands. The existence of flow creates an illusion of higher MAP, because flowing water is usually less thermally and evaporatively coupled to the atmosphere than standing water. The MAP levels of 400 to $600 \mathrm{~mm}$ reported by Forester and Smith (1994) probably did exist in this area but only at higher elevation where present MAP is also higher. Thus, the change in MAP between today and the last glacial interval on the valley floor, where MAP is $112 \mathrm{~mm}$, was probably less than about four times modern.

The ostracode assemblages found in unit D commonly live in eastern Washington and western Minnesota today where MAT is 5 to $7^{\circ} \mathrm{C}$, and effective moisture deficits are about $200 \mathrm{~mm}$ or roughly five times lower than that of the modern-day Las Vegas Valley (Forester and Smith, 1994). The MAT values (like MAP) may be too cold for valley bottoms but, considering factors such as cold air drainage, they may be closer to actual paleovalues than is MAP. Reduced MAT in the Las Vegas Valley must have contributed significantly to changes in past levels of effective moisture, along with a probable double increase in MAP.

The ostracodes found in unit E contain more spring species and fewer wetland and aquifer species. Because section OCI-11 is from the valley floor, large wetlands, if they existed, would have covered this site, so the absence of wetland taxa implies fewer or smaller wetlands, which indicates lower effective moisture relative to the glacial intervals.

The radiocarbon ages document the timing of the growth and decline of the unit D and $\mathrm{E}$ wetlands. The wetlands existed around $36 \mathrm{ka}$, and they persisted until $12.1 \mathrm{ka}$ at section OCI-11 (fig. 10) and to somewhat younger times in nearby sections. The growth and persistence of wetlands in southern Nevada is 


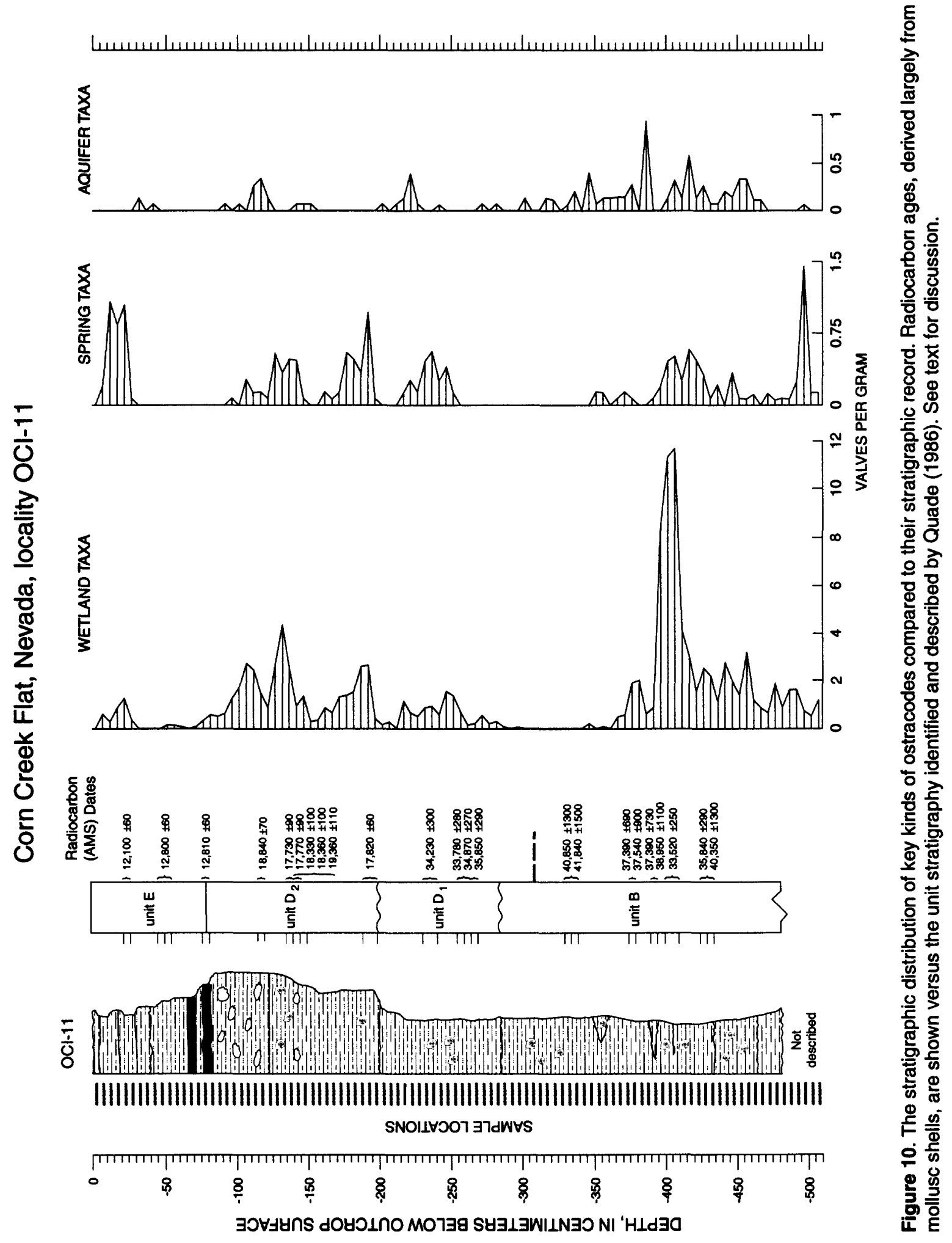


correlated to Northern Hemisphere summer insolation minima associated with the last glacial cycle. This insolation minimum is further associated with the expansion of the Polar cell into this region, resulting in increased effective moisture, increased recharge, and higher regional water tables that, in turn, gave rise to the wetlands. Similarly, the eventual loss of wetlands is correlated with a rise in Northern Hemisphere insolation to its maximal value at $12 \mathrm{ka}$ and the retreat of the Polar cell from the region. Such changes demonstrate a linkage between millennial-scale climate forcing functions and regional-scale hydrology in southern Nevada.

\section{Terrestrial Vegetation Records}

\section{Introduction}

Periods of wetter climate, their frequencies, magnitudes, rates of onset and decline, and shifts in their seasonal distribution have been identified using plant remains from woodrat middens. One hundred ninety-five radiocarbon dates on plant macrofossils from 122 woodrat-midden strata collected in southern Nevada provide climate proxy data to interpret past levels of MAP and MAT. This study has focused on (1) direct and high-precision dating of key plant species, and (2) multiple dates on several species from the same stratum to confirm the ages of the woodrat midden strata.

\section{Modern Climate and Vegetation of Southern Nevadan Deserts}

Yucca Mountain is located in the Mojave Desert, just south of the boundary with the Great Basin Desert to the north (Hunt, 1973) (fig. 1, 11). The climate and vegetation in the region are influenced by three climatic systems (Houghton, 1969; Houghton and others, 1975):

Pacific: A regime dominated by maritime polar air masses created when the edge of the Polar cell moves south in winter. These cool, moist air masses from the Pacific Ocean produce cool, wet winters and hot, dry summers. Plant species favoring this regime extend into southern Nevada from west and northwest of Yucca Mountain.

Gulf: A regime dominated by maritime and continental tropical air masses resulting from strengthened flow from the Hadley cell into the desert belts. These warm, moist air masses entering from either the Gulf of Mexico or the Gulf of California produce warm, dry winters and hot, moist summers with mid-summer torrential rainfall originating during convective storms. Plants such as creosote (Larrea tridentata) bush and perhaps pinyon pine (Pinus monophylla) that favor warmer temperatures and summer rainfall extend into this area from the desert to the south.

Continental: A regime dominated by continental polar and arctic air masses derived when the Polar cell moves into and south of the Yucca Mountain region. These cold, dry air masses from the North American interior extend into the Great Basin from the northeast during the winter. Such outbreaks restrict the plant species able to grow within the area to those with physiological limits tolerant of cold, dry winters coupled with periodic drought.

Southern Nevadan climates and vegetation are further complicated by the strong rainshadow effect of the Sierra Nevada to the west. The accelerated rise of these mountains during the Pleistocene (the past $1.8 \mathrm{My}$ ) accentuated the rainshadow effect (Thompson, 1991).

Vegetation in the Yucca Mountain region today is diverse (table 1). At lower elevations, it is composed of warm Mojave Desert species from the south; at middle elevations, a mix of southern woodland and Great Basin cold desert vegetation from the north is present; and, at highest elevations, an endemic subalpine component is combined with montane and subalpine elements, indicating links to the Rocky Mountains and moderate connections to the Sierra Nevada (Cronquist and others, 1972; Charlet, 1995).

\section{Results and Discussion}

The presence or absence of limber pine (Pinus flexilis) and white fir (Abies concolor) in the late Pleistocene woodrat-midden record identifies cooler-drier or warmer-wetter climate regimes. During certain periods, these trees grew at elevations much lower than today. Modern elevational and geographic distributions are used to infer past climatic conditions. 


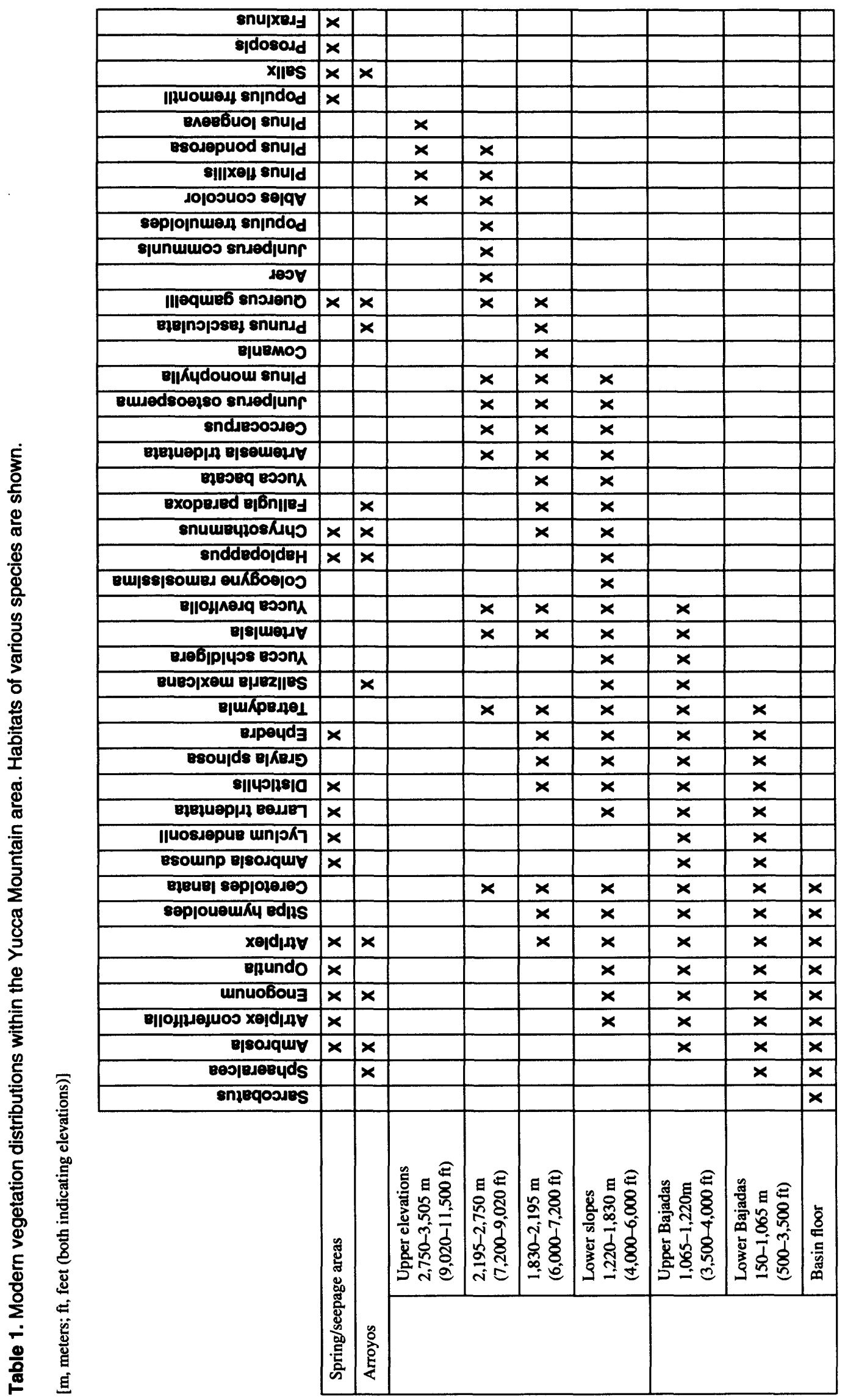




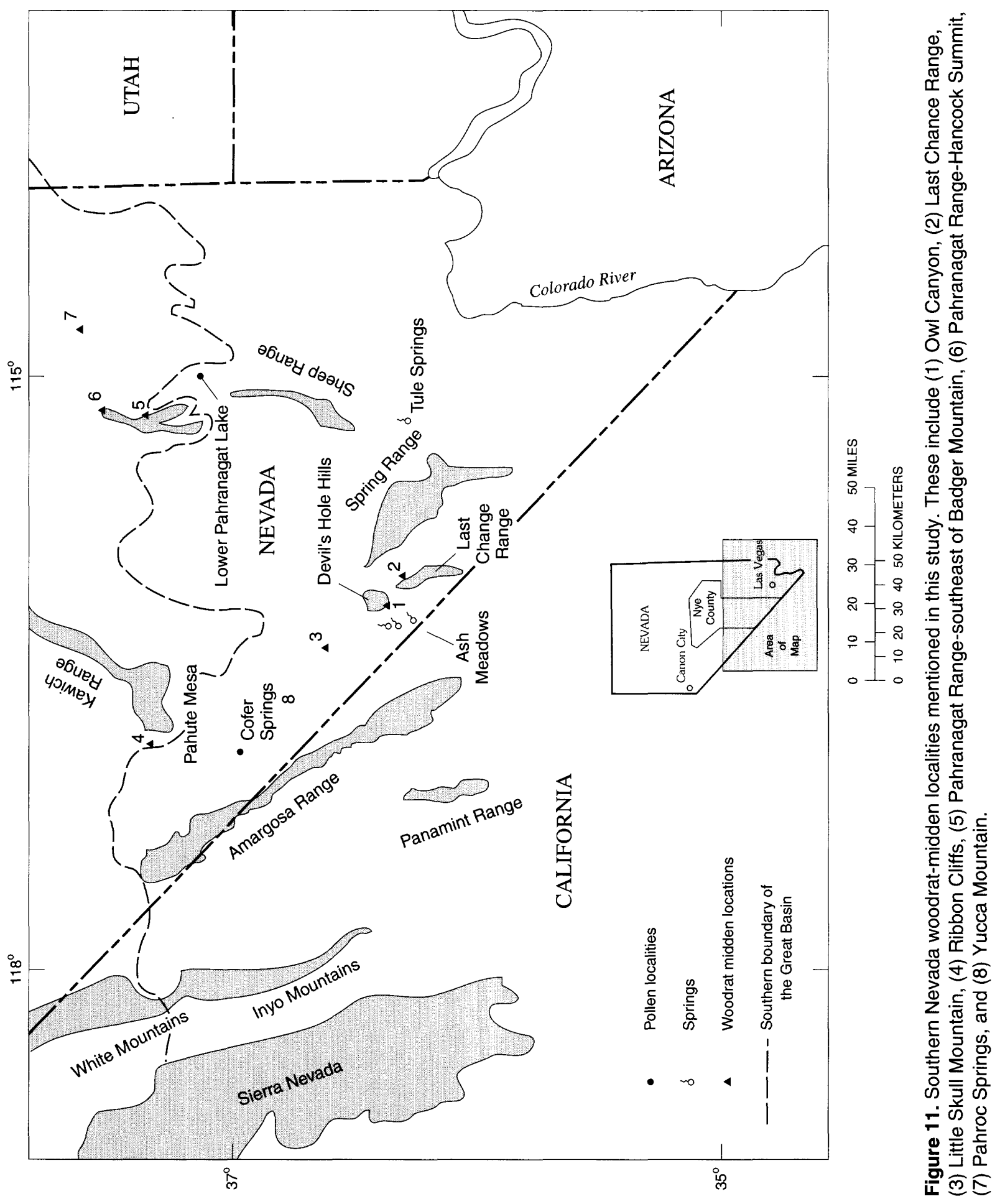




\section{Limber Pine}

The current habitat of limber pine is characterized by dry, continental climate with wide annual and diurnal temperature fluctuations. The mean annual precipitation (MAP) ranges from 380 to $560 \mathrm{~mm}$ and is distributed evenly throughout the year (Steele, 1990). Limber pine is common between 1,981- and 2,743-m elevation, primarily in the Rocky Mountains. It presently grows between 2,195- and 3,505-m elevation on the Nevada Test Site (Beatley, 1976).

\section{White Fir}

The taxonomy of white fir recently has been amended to split the population into the Sierra white fir (Abies lowiana) and Rocky Mountain white fir (Abies concolor) by the Flora of North America Editorial Committee (1993); most descriptions of western North American plants still join the two species as Abies concolor. No attempt yet has been made to differentiate the species in our midden material, although this may be possible in the future.

Sierra white fir grows in areas dominated by the moist Pacific climate regime with MAP ranges from 890 to $1,240 \mathrm{~cm}$. Rocky Mountain white fir grows on high mountains dominated by drier continental climate with MAP ranges from $510 \mathrm{~mm}$ to greater than $890 \mathrm{~mm}$. White fir is common between 1,200- and 2,100-m elevation (Laacke, 1990). Isolated colonies of white fir grow in the Spring Mountains and on Bald Mountain in the Groom Range of Nevada (U.S. Air Force, 1986). Currently, the colonies are associated with the Rocky Mountain taxon, but, during the Pleistocene, either or both of the white fir species could have inhabited southern Nevada.

\section{Fossil Record}

\section{Spatial and Chronological Continuity of Data}

The woodrat-midden data base can be affected by (1) environmental limits that constrain the geographical distribution of woodrats, and (2) wetter climates that could destroy woodrat middens after formation. Today, two woodrat species elevationally overlap from valley floors (desert woodrat, Neotoma lepida) to the mountain tops (bushy-tailed woodrat, $N$. cinerea), occupying all but the most extreme habitats in the Great Basin (Hall, 1995). The current range of the bushy-tailed woodrat, which seems to have been the dominant species in the Great Basin during the late Pleistocene, includes the southern Yukon where the climate is substantially wetter and colder than that of the modern Great Basin. Woodrat middens of varying ages are found throughout the elevational and geographic ranges of these two species.

Widely divergent radiocarbon dates on materials obtained from single woodrat midden strata for the late Quaternary indicate that midden resolution and destruction was accelerated prior to $14 \mathrm{ka}$ (Spaulding, 1985, 1990; Van Devender and others, 1986).

Although only 23 percent of the dated woodrat midden strata in the Yucca Mountain area are older than this date, climate regimes are adequately represented.

\section{Timing}

Limber pine appears regularly in the record between approximately 13 to $11 \mathrm{ka}, 21$ to $14 \mathrm{ka}, 26.5$ to $23 \mathrm{ka}$, and 33 to $29 \mathrm{ka}$ (fig. 12). Four periods of white fir occurrence at elevations lower than today center around 13 to $12 \mathrm{ka}, 16$ to $14 \mathrm{ka}, 26$ to $21 \mathrm{ka}$, and about 35 to $32 \mathrm{ka}$ (fig. 13). Periods when climate appears to exclude white fir from communities with abundant limber pine occur from 21 to 16 and 32 to $29 \mathrm{ka}$. Periods when climate appears to include white fir without major limber pine association are from 23 to 21 and 35 to $33 \mathrm{ka}$.

\section{Eievationai Displacement}

The lower elevation of middens containing limber pine and/or white fir macrofossils coincides with the base of modern semiarid pinyon-juniper woodland, about $1,220 \mathrm{~m}$. The displacement of limber pine and white fir to lower elevations by as much as $1,000 \mathrm{~m}$ during the Pleistocene records significant real increases in MAP that cannot be explained simply through reduced MAT. Corroborating data indicate limber pine was growing between 1,500 and 1,300 m in the Eleana, Sheep, and Spring Ranges, Fortymile Canyon, and Clark Mountain during the Pleistocene (W.G. Spaulding, 1981, 1985, 1990; Dames and Moore, written commun., 1994; Mead and others, 1978; Mehringer and Ferguson, 1969).

\section{Environmental Parameters}

Although limber pine and white fir grow together today in some places, white fir typically requires warmer winter temperatures and more annual 
precipitation than limber pine. Where they occur together, upper elevations of white fir overlap with lower elevations of limber pine. Because white fir commonly occurs at elevations well below those of limber pine, fir appears to tolerate/require warmer temperatures than limber pine. Limber pine has a lower MAP requirement ( 380 to $560 \mathrm{~mm}$ ) than does white fir (510 to $1240 \mathrm{~mm}$ ). Limber pine prefers precipitation evenly distributed throughout the year, whereas white fir typically receives more than 80 percent of its annual precipitation in the form of snow in the areas of its distribution.

Pleistocene associations of Utah juniper (Juniperus osteosperma) with limber pine and white fir can be used further to constrain estimates of late Pleistocene precipitation (fig. 14). Directly dated late Pleistocene macrofossils from woodrat middens throughout southern Nevada indicate that Utah juniper occurred throughout a wide elevational range during the late

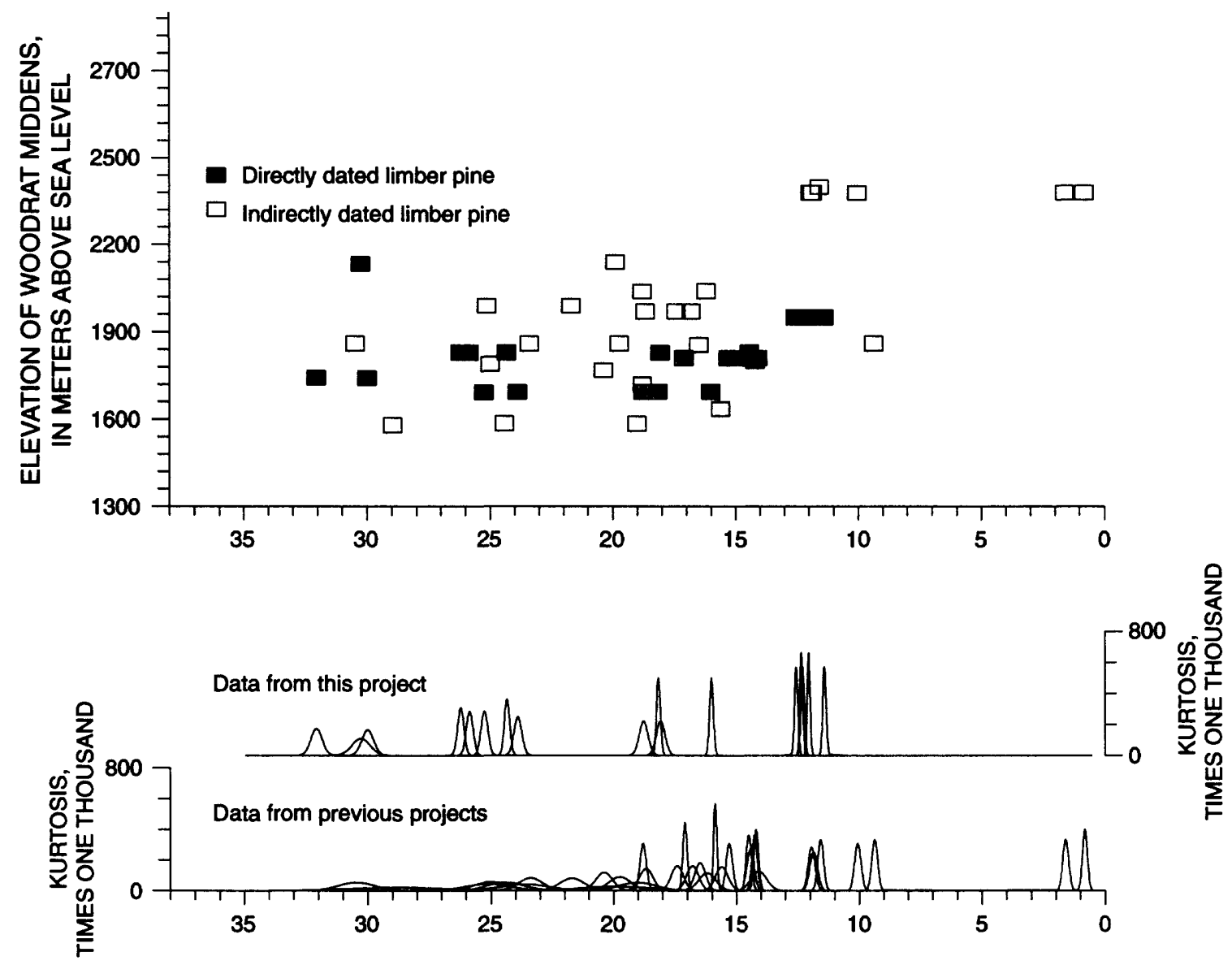

RADIOCARBON AGE, IN THOUSAND YEARS BEFORE PRESENT

Flgure 12. Age plotted against elevation for limber pine in the Yucca Mountain area, Nevada. Top, chronologic plot of the elevational distribution of directly dated limber pine macrofossils from ancient woodrat middens from a 200-km radius around Yucca Mountain (Spaulding, 1981; Mead and others, 1978; Mehringer and Ferguson, 1969; W.G. Spaulding, Dames and Moore, Inc., written commun., 1994). Dashed line is the approximate lower elevational distribution limit of limber pine in the Sheep Range today. Middle, radiocarbon dates on limber pine from Spaulding (1985) plotted as a normal distribution at three standard deviations around the mean. Bottom, radiocarbon dates on limber pine for other studies plotted as a normal distribution at three standard deviations around the mean. For the middle and bottom plots, the normal distributions are a measure of radiocarbon date precision, that is, the more pointed the distribution curve, the more precise the date, and the flatter the curve, the less precise the radiocarbon date. 

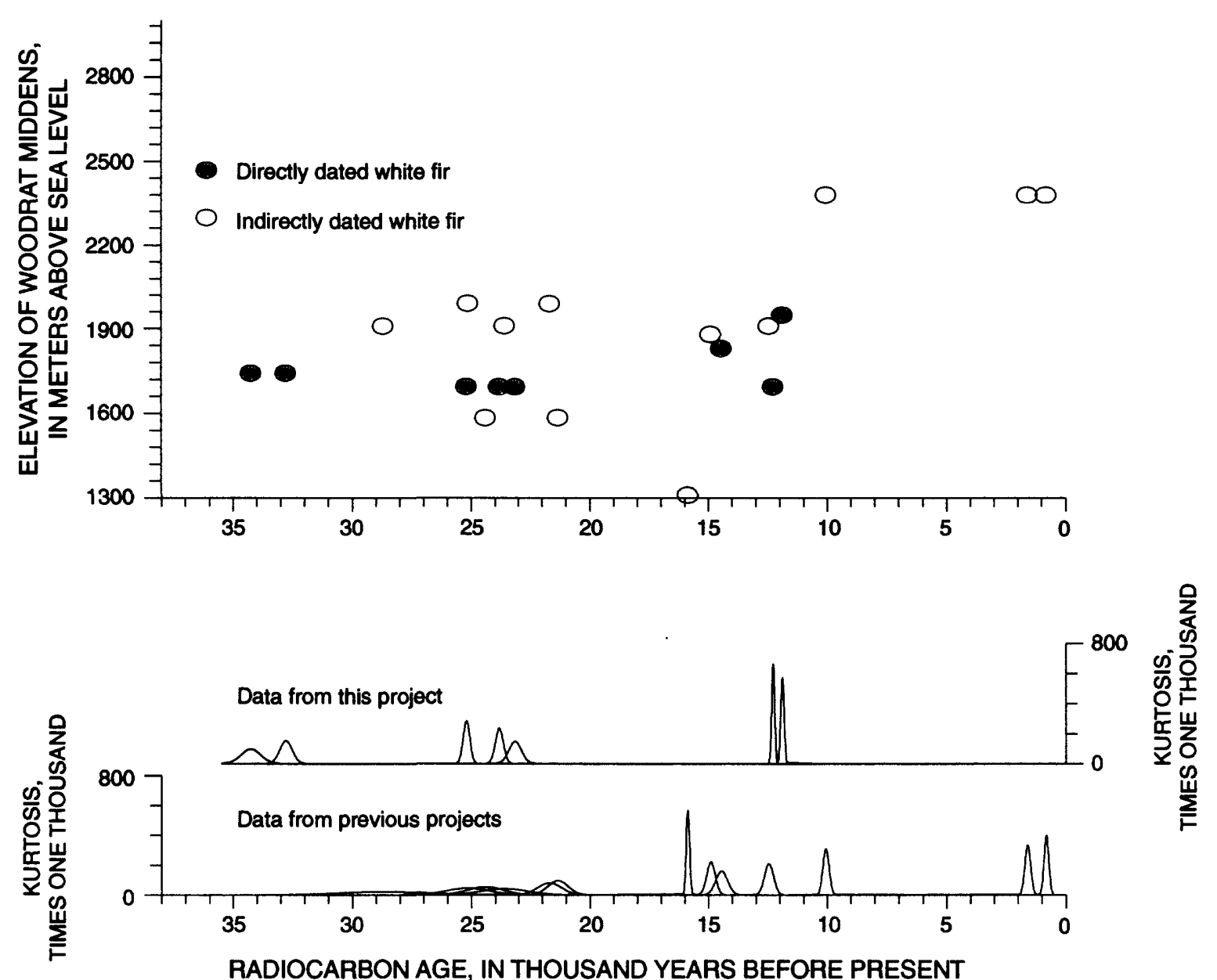

Flgure 13. Age plotted against elevation for white fir in the Yucca Mountain area, Nevada. Top, chronologic plot of the elevational distribution of directly dated white fir macrofossils from ancient woodrat middens from a 200-km radius around Yucca Mountain (our own data and Spaulding, 1981; Mead and others, 1978; Mehringer and Ferguson, 1969; dashed line is the approximate lower elevational distribution limit of white fir in the Sheep Range today); middle, radiocarbon dates on white fir for this study plotted as a normal distribution at three standard deviations around the mean; and bottom, radiocarbon dates on white fir from Spaulding (1985) plotted as a normal distribution at three standard deviations around the mean. For the middle and bottom plots, the normal distributions are a measure of radiocarbon date precision, that is, the more pointed the distribution curve, the more precise the date, and the flatter the curve, the less precise the radiocarbon date.

Pleistocene (Wells and Jorgensen, 1964; Wells and Berger, 1967; W.G. Spaulding, 1977, 1981, 1985, 1990, Dames and Moore, written commun., 1994; Mehringer and Warren, 1976; Wells and Woodcock, 1985). At upper elevations, it commonly occurred in association with limber pine and in some cases with white fir (Mehringer and Ferguson, 1969; Spaulding, $1977,1981,1985,1990)$. Due to woodrat collection bias, juniper is common to abundant in most late Pleistocene woodrat-midden strata; this does not mean that it was consistently the most abundant species at all elevations. Both woodrat-midden and pollen evidence indicate that the bulk of Utah juniper's Pleistocene distribution lay at lower elevations and not at upper elevations (Mehringer, 1967; Wells and Woodcock, 1985).

Today, the MAP of Utah juniper ranges between 410 to $250 \mathrm{~mm}$ (U.S. Forest Service SCS DATA BANK; U.S. Air Force, 1986). The lower MAP value of limber pine overlaps with the upper MAP value of juniper. This indicates a minimum MAP of 380 to $410 \mathrm{~mm}$ where the two species occur together in the fossil record. The minimum MAP of Rocky Mountain white fir is higher: $510 \mathrm{~mm}$. This would indicate a MAP above $410 \mathrm{~mm}$ or increased winter soil moisture during the time periods containing all three species. 


\section{CHRONOLOGICAL DISTRIBUTION OF DIRECTLY DATED (AMS) SOUTHERN GREAT BASIN TREE SPECIES}

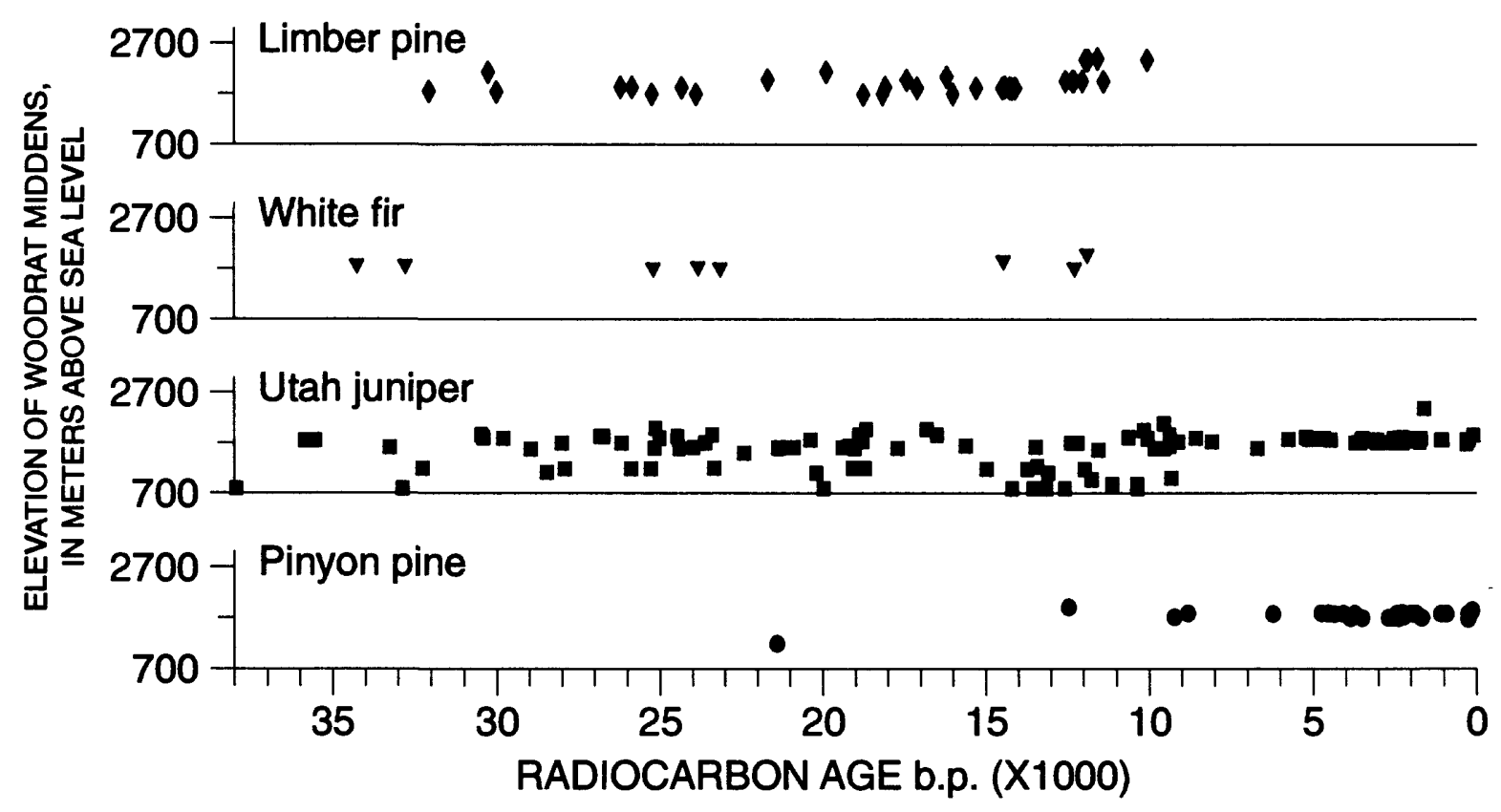

Figure 14. The distribution of directly dated limber pine, white fir, Utah juniper, and pinyon pine through time and by elevation from ancient woodrat middens from a $200-\mathrm{km}$ radius around Yucca Mountain, Nevada (our own data and Spaulding, 1981; Mead and others, 1978; Mehringer and Ferguson, 1969; and W.G. Spaulding, Dames and Moore, written commun., 1994). Eight additional radiocarbon-dated occurrences of limber pine are included in this figure that were not used in figure 12. These are dates on a mixture of both limber and bristlecone pine, not technically a direct date only on limber pine. However, they do record the occurrence of limber pine in these middens at those times. Dots provide an impression of the chronological continuity or lack thereof, of the various species. The episodic nature through time of the occurrence of limber pine, white fir, and pinyon pine and their limited spatial ranges can be gauged by comparing their occurrences against the nearly continuous chronologic and geographic distribution of Utah juniper for the same area (many of the same localities).

Further refinement of Pleistocene MAP ranges associated with limber pine and white fir can be achieved through the examination of associated shrubs, forbs, and grasses. A total of 56 taxa were identified, and 18 of these were determined to be the best climatic indicators (table 2).

In general, the more mesic (wetter) shrubs (for example, sagebrush, Artemisia spp.) found in association with limber pine and white fir during the Pleistocene have upper MAP ranges around 400 to $420 \mathrm{~mm}$. More xeric (drier) shrubs (for example, shadscale, Atriplex spp., and winterfat, Ceratoides sp.) have upper MAP ranges around 150 to $250 \mathrm{~mm}$ U.S. Forest Service SCS DATA BANK). These data indicate that effective moisture during periods of wetter climate should be constrained toward the more xeric (drier) end of the MAP requirements of limber pine during the glacial maximum and the more mesic end of the MAP scale of limber pine during periods when white fir occurred. Thus, if the lower MAP range of the modern juniper community is compared with the lower MAP values of limber pine, a MAP 1.9 times the present MAP (an increase from a MAP value of 200 to $380 \mathrm{~mm}$ ) can be derived. (Ongoing refinement of MAP values may change the final percentage of increase.) This increase allowed limber pine to migrate through the current elevational distribution of Utah juniper to at least the current lower boundary of juniper. At lower elevations, the movement of Utah juniper into areas currently occupied by shadscale would require MAP 1.3 times the present (a shift from 150 to $200 \mathrm{~mm}$ ). 


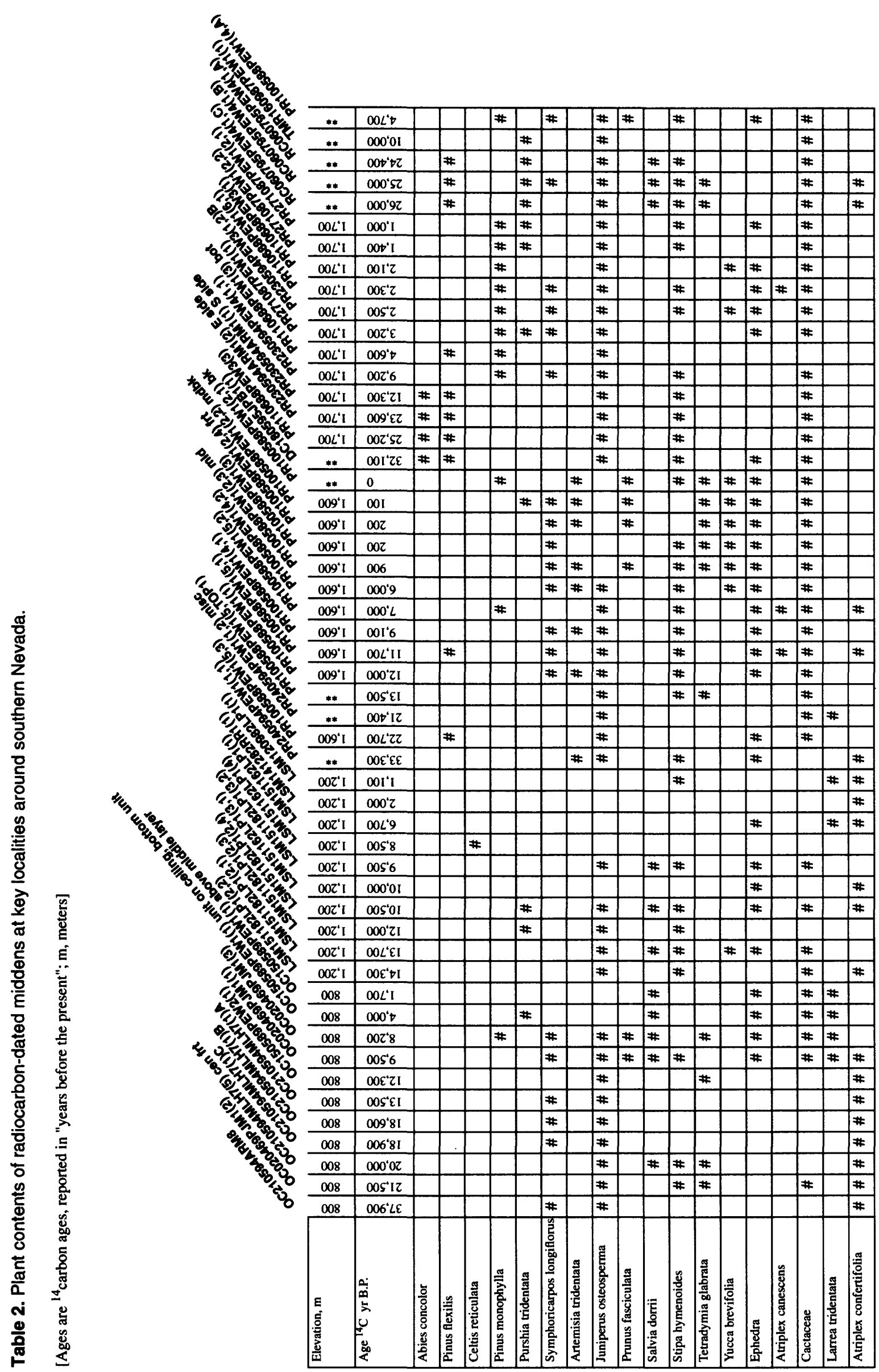




\section{Pleistocene Wet Periods}

Utah juniper and limber pine were the common trees at intermediate elevations on the southern Nevadan landscape from 12 to $34 \mathrm{ka}$. Brief appearances of white fir also occurred in these communities. Juniper and limber pine imply long periods of dry continental climate accompanied by weak storm systems, whereas the white fir episodes indicate strengthened moist-air flow off the Pacific. This probably resulted in a precipitation shift from little seasonal differentiation to increased winter precipitation. Lowered MAT would result in reduced evaporation rates also implied by the wetlands common to this region during the glacial intervals. The presence of limber pine at lower elevations could be due to temperature-induced increases in effective moisture, but temperature-driven gains in effective moisture alone cannot explain the migration of white fir.

Vegetation at intermediate elevations during the Last Glacial Maximum (LGM) (about 21 to $16 \mathrm{ka}$ radiocarbon) is characterized by limber pine without white fir, indicating that southern Nevada was dominated by dry continental climate with precipitation evenly distributed throughout the year, a pattern that indicates the Polar cell was resident throughout the year.

White fir appeared in intermediate-elevation woodrat middens during the slightly warmer periods bracketing the LGM [that is, as climate was cooling down from warmer episodes enroute to the LGM and as it was warming after the LGM (Thompson and others, 1993)]. Because white fir favors warmer MAT and higher MAP than does limber pine, a real increase in MAP and a shift toward an increased winter precipitation component, perhaps as snow, is indicated just prior to and after the LGM. These conditions are consistent with part or all of the year being under westerly flow within a compressed Ferrel cell. The likelihood of Ferrel cell circulation bringing wet maritime polar air to much of Nevada is indicated because white fir episodes coincide with whitebark pine (Pinus albicaulis) (a moisture-loving tree) in northern Nevada. Radiocarbon date distributions currently available from woodrat midden macrofossils indicate that the durations of these periods appear to be relatively short, less than 1500 years, and that onset and termination were quite sudden as would be expected if the cause of the climate change was related to the position of the westerlies.

\section{Conclusions and Summary}

\section{Conclusions}

During the late Pleistocene (40 to $12 \mathrm{ka}$ ), effective moisture was much higher than under modern regimes throughout southern Nevada. Much of the rise in effective moisture may be explained by greatly reduced temperatures in combination with modest rises in MAP. Short episodes of 1- to 2-ky duration punctuate these otherwise cold and dry periods; the wettest of these are centered on 23 to $21 \mathrm{ka}$ and 35 to $33 \mathrm{ka}$. Various tree species found in the middens indicate the climate interpretations may be explained by the existence of the Polar cell in the region during most of the late Pleistocene, with episodes of intense westerly flow probably related to a constricted Ferrel cell accounting for the wet episodes.

Known MAP requirements for key plant species indicate rapid shifts toward century- to millennia-long wetter winter precipitation patterns throughout Nevada during the 35- to 33-ka and 23- to 21-ka periods. Preliminary interpretation of MAP in southern Nevada implies increases in the range of MAP just under two times (90 percent) at higher elevation (between 1,500 and $2,000 \mathrm{~m}$ ) and perhaps one-third or half again as great (30 percent) at lower elevation (700 to $1,500 \mathrm{~m})$.

Precipitation gradients increased significantly during the Pleistocene. MAP was approximately 1.3 times what it is today at about 750 -m elevation, based upon the displacement of Utah juniper. Limber pine displacement indicates that MAP was approximately 1.9 times what it is today at about $1,500 \mathrm{~m}$. If the increase in regional MAP had been regular, the expected increase would be the same at all elevations. However, the difference in MAP between these two elevations during the Pleistocene reveals that the precipitation increase was about 60 percent greater at elevations of $1,500 \mathrm{~m}$ than it was at $750 \mathrm{~m}$. Lack of data above $2,000 \mathrm{~m}$ for the Pleistocene prevents extrapolation of precipitation increases to higher elevations using plant remains from woodrat middens. 


\section{Summary}

Based upon occurrences of limber pine and/or white fir and using the MAPs derived from the vegetation data summarized above, we have generated the following sequence of climate between 35 and $12 \mathrm{ka}$. This applies only for elevations around $1,500 \mathrm{~m}$. At elevations around $750 \mathrm{~m}$, estimates should be about 50 percent of those at $1,500 \mathrm{~m}$. Above $2,000 \mathrm{~m}$, absence of data prevents estimation. Climate designations of very wet, wet, and dry are relative.

$\begin{array}{lll}13 \text { to } 12 \mathrm{ka} & \text { wet period } & \text { MAP about } 460-560 \mathrm{~mm} \\ 14 \text { to } 13 \mathrm{ka} & \text { dry period } & \text { MAP about } 410-460 \mathrm{~mm} \\ 16 \text { to } 14 \mathrm{ka} & \text { wet period } & \text { MAP about } 460-560 \mathrm{~mm} \\ 21 \text { to } 16 \mathrm{ka} & \text { dry period } & \text { MAP about } 410-460 \mathrm{~mm} \\ 23 \text { to } 21 \mathrm{ka} & \text { very wet period } & \text { MAP about } 560-640 \mathrm{~mm} \\ 26.5 \text { to } 23 \mathrm{ka} & \text { wet period } & \text { MAP about } 460-560 \mathrm{~mm} \\ 33 \text { to } 26.5 \mathrm{ka} & \text { dry period } & \text { MAP about } 410-460 \mathrm{~mm} \\ \text { about } 35-33 & \text { very wet Period } & \text { MAP about } 560-640 \mathrm{~mm}\end{array}$

\section{Comparison of Aquatic and Terrestrlal Records}

The interpretations of past climate based on aquatic and terrestrial records show remarkable convergence. The persistence of wetlands supported by discharge from the regional aquifer and flowing springs deriving their waters from alluvial fans implies a much higher level of effective moisture than present today near Yucca Mountain. Ostracodes lived in those wetlands, and today similar communities commonly live in western Minnesota and eastern Washington, with the present-day boundary of the Polar and Ferrel cells.

The aquatic and terrestrial data sets support an interpretation for the last glacial cycle characterized by the residence of Polar cell air during much of the glacial period. The presence of the Polar cell would produce cold dry air just as it does today. Consequently, mean evaporation substantially was reduced, especially because the present-day dry, hot summer weather pattern would not exist during the glacial intervals. MAP also was higher during much of the glacial periods, but percentage gains were elevation dependent, showing a greater increase upslope relative to valley bottoms. Snow most likely contributed to the higher levels of MAP.

The white fir periods, persisting for only 0.5 to $2 \mathrm{ky}$, appear to represent periods when the influence of the Polar cell on the region's climate was weakened and replaced by strong westerly flow, probably derived from a Ferrel cell constricted between the expanded Polar cell and the Hadley cell. This westerly flow brought maritime (polar?) air into the region, probably from both the west and the southwest. Consequently, both MAT and MAP would have increased during these periods. Preliminary inspection of radiocarbon ages derived from the wetland deposits indicates much of these sediments was deposited during the white fir periods, although issues such as radiocarbon reservoir effects in the aquatic records must be resolved to establish this relation.

\section{Late Quaternary History of Surficial Deposits at Yucca Mountain: A Record of Geomorphic and Surface Hydrologic Response to Climate Change}

The characteristics and distribution of surficial deposits at Yucca Mountain, along with the ages of some of the deposits, provide a basis for explaining the hydrologic and geomorphic history of the area (Lundstrom, Westling, and others, in press; Lundstrom, Mahan, and Paces, in press; Lundstrom, Whitney, and others, in press; Lundstrom and Taylor, in press). The surface deposits are mainly gravelly alluvium in the valleys and eolian-dominated alluvial and colluvial soils on the hillside areas. These deposits accumulated in the late Quaternary during climatic conditions that were associated with more geomorphic and surface hydrologic activity than in today's climate. Understanding these past changes provides a way to estimate future climate-induced changes and provides an indication of the potential nature of future surface-water environments. 


\section{The Fluvial Record of Fortymlle Wash}

Fortymile Wash, an ephemeral desert-wash tributary to the Amargosa River, is the major surfacewater drainage on the eastern side of Yucca Mountain and for a much larger area of uplands to the northeast (fig. 1). The alluvial history of Fortymile Wash has been constrained by thermoluminescence (TL) and ${ }^{230} \mathrm{Th} / \mathrm{U}$ dating of the surficial and buried soils.

The relations between the alluvial materials, the soils, and their ages together with other local climate records indicate the following preliminary hypothesis: Fortymile Wash aggrades during interglacial and transitional climates that produce high-intensity rainfall and runoff. These intense rainfall and runoff events erode hillslopes, including those of Yucca Mountain, and thereby supply abundant sediment to the fluvial system. Fanhead incision on Fortymile Wash occurs during relatively cool and moist climates when hillslopes are relatively stable and supply little sediment to the flows of Fortymile Wash, which were perhaps sustained by concentrated spring snowmelt from its upper basin. The discussion below describes the ages and relations of the surficial deposits that were used to support this hypothesis.

The Quaternary history of lower Fortymile Wash is characterized by the aggradation of a large alluvial fan extending into the central Amargosa Desert with some incision in the upper part of the fan. Although significant aggradation has occurred on the lower central part of this fan during the Holocene, a larger episode of aggradation occurred during the Pleistocene between about 120 and $50 \mathrm{ka}$, resulting in deposition of the uppermost layer of coarse gravel that forms the present high terrace surface near Yucca Mountain.

Incision of the uppermost part of the Fortymile Wash fan occurred before the last glacial maximum. This is indicated by the minimum ages of secondary U-rich opal/carbonate coats on clasts, and by the presence of a silty argillic horizon in the surface soil (Lundstrom, Westling, and others, in press; Lundstrom, Mahan, and Paces, in press; Lundstrom, Whitney, and others, in press). Fanhead incision reaches a maximum of about $25 \mathrm{~m}$ near well $\mathrm{J}-13$ and at the latitude of the potential repository.

Younger inset alluvial units that occur along the incised upper part of the Fortymile Fan converge southward with the older late Pleistocene alluvium which forms most of the upper fan surface. Bouldery Holocene alluvium, which spread across the lower central part of the Fortymile Fan in the vicinity of U.S. Highway 95 to a width of about $3 \mathrm{~km}$, is characterized by a recognizable depositional morphology and weakly developed soils. The thickness of this recent alluvium generally is not exposed. However, in one borrow pit near U.S. Highway 95, the alluvium is about 3 to $4-\mathrm{m}$ thick and lies above a buried soil. The latter may mark the top of a late Pleistocene alluvial unit associated with fanhead incision in yet older, unexposed alluvium occurring from about 40 to $25 \mathrm{ka}$.

During the Holocene and especially during the transition to the Holocene (about 15 to $8 \mathrm{ka}$ ), hillslope erosion supplied sediment to Fortymile Wash, which aggraded over its lower reach. Analysis of Holocene alluvium indicates erosion of an average of at least $60 \mathrm{~cm}$ of colluvium on Yucca Mountain (or about $18 \mathrm{~cm}$ of bedrock equivalent) eroded over the past $15 \mathrm{ky}$, but it is not known what quantity was transported into Fortymile Wash. Local hillslope erosion at Jake Ridge by a high-intensity convective storm in July 1984 supplied sediment to Fortymile Wash (Coe and others, 1995).

Most major tributaries to Fortymile Wash have supplied young sediment to Fortymile Wash as seen, for example, by young tributary fans built into and truncated by Fortymile Wash. Further, the downwash decrease in the portion of basaltic clasts in young Fortymile gravel is due to dilution by non-basaltic alluvium from tributary drainages below upper Fortymile Canyon (Lundstrom and Warren, 1994).

Aggradation during sediment transport events along Fortymile Wash is an expected consequence of streamflow infiltration along the channel. The downwash decrease of peak flows due to infiltration was documented for events in 1984 (Savard and Beck, 1994). Infiltration along Fortymile Wash is a major component of a regional infiltration model based, in part, on channel morphology. The geochemistry and distribution of apparent age of ground water beneath the fan of lower Fortymile Wash indicates that this process also was important during transition to the Holocene (Claassen, 1985).

Channel infiltration and sediment deposition is magnified where the young Fortymile Wash alluvium spreads out as a fan over the older surface (the intersection point). The intersection point reflects a 
decrease in the channel gradient and in flow rate, so the stream loses its power to carry the sediment. Aggradation is, thus, magnified in this area, tending to move the intersection point upwash with time. Therefore, a prolonged period of system-wide aggradation, magnified at the intersection point, would spread a younger alluvium over an older alluvial surface and its soil.

Spatial and temporal variability in the lithologic clast compositions of Fortymile gravels supports this model of landscape response to climate change. In contrast to Holocene alluvium in which basaltic clasts decrease proportionally down Fortymile Wash, the alluvial unit (deposited 35 to $25 \mathrm{ka}$ ) associated with the fanhead incision maintains a high portion of basaltic clasts. This indicates that during fanhead incision, the nonbasaltic uplands supplied relatively little sediment to lower Fortymile Wash, probably because climates at that time did not generate intense runoff or erosion from hillslopes below about $1,500 \mathrm{~m}$ in altitude, such as Yucca Mountain. However, major stream discharge was required to produce $25 \mathrm{~m}$ of fanhead incision on Fortymile Wash, which seems likely to have occurred during seasonal snowmelt from the higher part of upper Fortymile Wash consistent with the paleoenvironmental records of Spaulding (1985, 1990, and written commun., 1994). The clast assemblage of older alluvial units underlying the high terrace and representing previous larger aggradational events has relatively sparse basaltic clasts, a distribution even more pronounced than in Holocene alluvium, indicating dilution by sediment supplied by erosion of hillslopes in the lower Fortymile Basin.

\section{Hydroclimatic Implications of Fortymile Wash History}

Fortymile Wash in today's climate is extremely ephemeral. Flow in the wash has been observed during parts of less than 30 days over the past 27 years anywhere along its main channel from Buckboard Mesa southward to its confluence with the Amargosa River channel. However, Fortymile Wash probably had perennial or sustained seasonal flow along at least portions of its length during wetter climates over the past $100 \mathrm{ky}$. In particular, perennial or at least seasonally sustained flow through Fortymile Canyon seems likely to have occurred from about 50 to $25 \mathrm{ka}$ when the fanhead was being incised. In central Fortymile
Canyon at the mouth of Pah Canyon, the ground-water table is about $28 \mathrm{~m}$ beneath the modern Fortymile Wash channel so that during wetter climates, a watertable rise in this geohydrologic bottleneck could have intersected the wash to provide perennial flow. Phreatophytes from a Neotoma (woodrat) midden yielded a radiocarbon date of about $47 \mathrm{ka}$, implying perennial flow occurred in this area (Spaulding, 1994).

Below Fortymile Canyon near well J-13, uranium series (U-series) data on samples from the inset terrace related to the period of incision yield dates of about 35 to $25 \mathrm{ka}$. The U-series data also indicate initial ${ }^{234} U /{ }^{238} U$ values intermediate between typical pedogenic values and those of local ground waters. This is interpreted to indicate that ground waters, derived from upgradient discharge, contributed significantly to seasonally sustained flows in Fortymile Wash. Seasonal drying probably also occurred to precipitate the dated minerals, which supports a snowmelt hypothesis. That hypothesis indicates the Fortymile Wash fanhead was incised by flows that occurred with no hillslope erosion during the cool-wet transition climate preceding the last glacial maximum. The magnitude and duration of seasonal flow must have decreased over lower Fortymile Wash in the area of fanhead entrenchment below Fortymile Canyon where surface flow was lost to infiltration. Today, the water table near $\mathrm{J}-13$ in the area of maximum fanhead incision is over $250 \mathrm{~m}$ below the surface, indicating that the water table would have remained below ground surface even during periods of higher effective moisture. However, the modern water table nears the fan surface southward and near the Stateline area. Samples from the spring discharge areas at the toe of the Fortymile Wash alluvial fan yield dates indicating the water table intersected the surface during the last two glacial periods.

Aggradation in Fortymile Wash resumed around $15 \mathrm{ka}$ when climate was in transition towards the interglacial (Holocene) period. That episode of aggradation continued until about $8 \mathrm{ka}$ and then largely ceased in a modern-like, very dry climate. Paradoxically, human artifacts occur along stretches of Fortymile Wash, and they seem to indicate a human presence that may indicate at least some episodes of seasonal flow. However, no aggradation associated with that potential flow has been identified. 
QUATERNARY HYDROLOGY

\section{Stable Isotope Geochemistry and Mineralogy}

Stable carbon and oxygen isotopes provide a way to distinguish the origins of secondary calcite and opal in the SZ and UZ (Whelan and Stuckless, 1990; Peterman and others, 1992b; Whelan and others, 1994). Stable oxygen isotope studies of minerals and/or waters permit estimation of temperature of mineral formation or isotopic ratio of the mineral's source water. In the case of the secondary minerals found in open spaces and on fractures within the UZ, the $\delta^{18} \mathrm{O}$ values of infiltrating waters were estimated from the $\delta^{18} \mathrm{O}$ values of calcite $\left(\mathrm{CaCO}_{3}\right)$ and/or opal $\left(\mathrm{SiO}_{2} \cdot \mathrm{nH}_{2} \mathrm{O}\right)$. Inasmuch as the $\delta^{18} \mathrm{O}$ of the infiltration directly reflects meteoric waters, these studies provide the only linkage between past precipitation (air-mass source) and UZ hydrology.

Secondary calcite carbon $\left(\delta^{13} \mathrm{C}\right)$ values in the $\mathrm{UZ}$ reflect the isotopic values of dissolved carbon species in the percolating waters and acquired within the soils during infiltration. Soil carbon dioxide generally arises from the oxidation of organic soil matter derived from the resident plant community. That $\mathrm{CO}_{2}$ has a $\delta^{13} \mathrm{C}$ value directly related to the ratio of plants using the $\mathrm{C} 3$ photosynthetic pathway to these using the $\mathrm{C} 4$ pathway. The $\mathrm{C} 3$ plants dominate under cooler and wetter climates (such as those of Pahute and Rainier Mesas near Yucca Mountain) and have $\delta^{13} \mathrm{C}$ values near -25 per mil. The $\mathrm{C} 4$ plants are better suited to hotter and drier climates such as that of Crater Flat and have $\delta^{13} \mathrm{C}$ values near -13 per mil (Quade and others, 1989). Calcite $\delta^{13} \mathrm{C}$ values, therefore, reflect the overlying plant community and provide information about the climate supporting these plants.

Isotopic studies of $\mathrm{SZ}$ calcite indicate it formed largely as an alteration phase during moderate temperature hydrothermal alteration roughly $10.5 \mathrm{Ma}$

(Broxton and others, 1987; Bish and Aronson, 1993). Therefore, they provide little, if any, information pertinent to reconstruction of past climates and are not discussed further.

Initial studies of UZ secondary minerals, however, concluded much of this record was deposited within the past $350 \mathrm{ky}$, some as recently as $26 \mathrm{ka}$ (Szabo and Kyser, 1990). Szabo and Kyser (1990) attributed deposition of the UZ calcite to infiltration of surface waters bearing the carbon isotopic signature of the overlying soils. They also attributed the regular $\delta^{18} \mathrm{O}$ decrease with depth in Yucca Mountain to warming of the descending waters along the presentday geothermal gradient (estimated to be about $34^{\circ} \mathrm{C} / \mathrm{km}$ (Sass and others, 1980). Coupled with the fine depositional laminae analogous to growth rings in trees (Whelan and Stuckless, 1992), these ages of formation indicate that the secondary minerals record the recent hydrologic response of the $\mathrm{UZ}$ to climate variability.

\section{Secondary Mineral Parageneses}

Study of mineral assemblage textures (macroand microscopic) establish the physical and temporal (paragenetic) relation between different mineral phases or successive mineral assemblages, thus providing hydrological evidence of their origins. Secondary mineral textures from UZ occurrences indicate that at least two major periods of mineral precipitation are common: an early period, predominantly composed of the silica phases quartz, chalcedony, and possibly opal with minor calcite and sparse, local fluorite, and a second period involving mostly calcite and opal. This early stage may include mineralization formed during tuff cooling or under a higher geothermal gradient. The later stages of mineralization largely produced calcite but also produced spatially and temporally common occurrences of opal. Fluid inclusion (Roedder and others, 1994) and stable carbon and oxygen (Whelan and others, 1994) data are completely consistent with formation of this later calcite from dilute, low-temperature meteoric waters percolating through the UZ during the Quaternary. Scanning-electron and plane-light microscopic observations indicate the UZ calcite and opal probably did not co-precipitate. Several occurrences, however, indicate multiple, cyclic, fine-scale depositional couplets of late calcite and opal that likely reflect short-term control by climate and/or UZ hydrochemistry (J.F. Whelan, R.J. Moscati, S.B.M. Allerton, and B.D. Marshall, U.S. Geological Survey, written commun., 1996). 


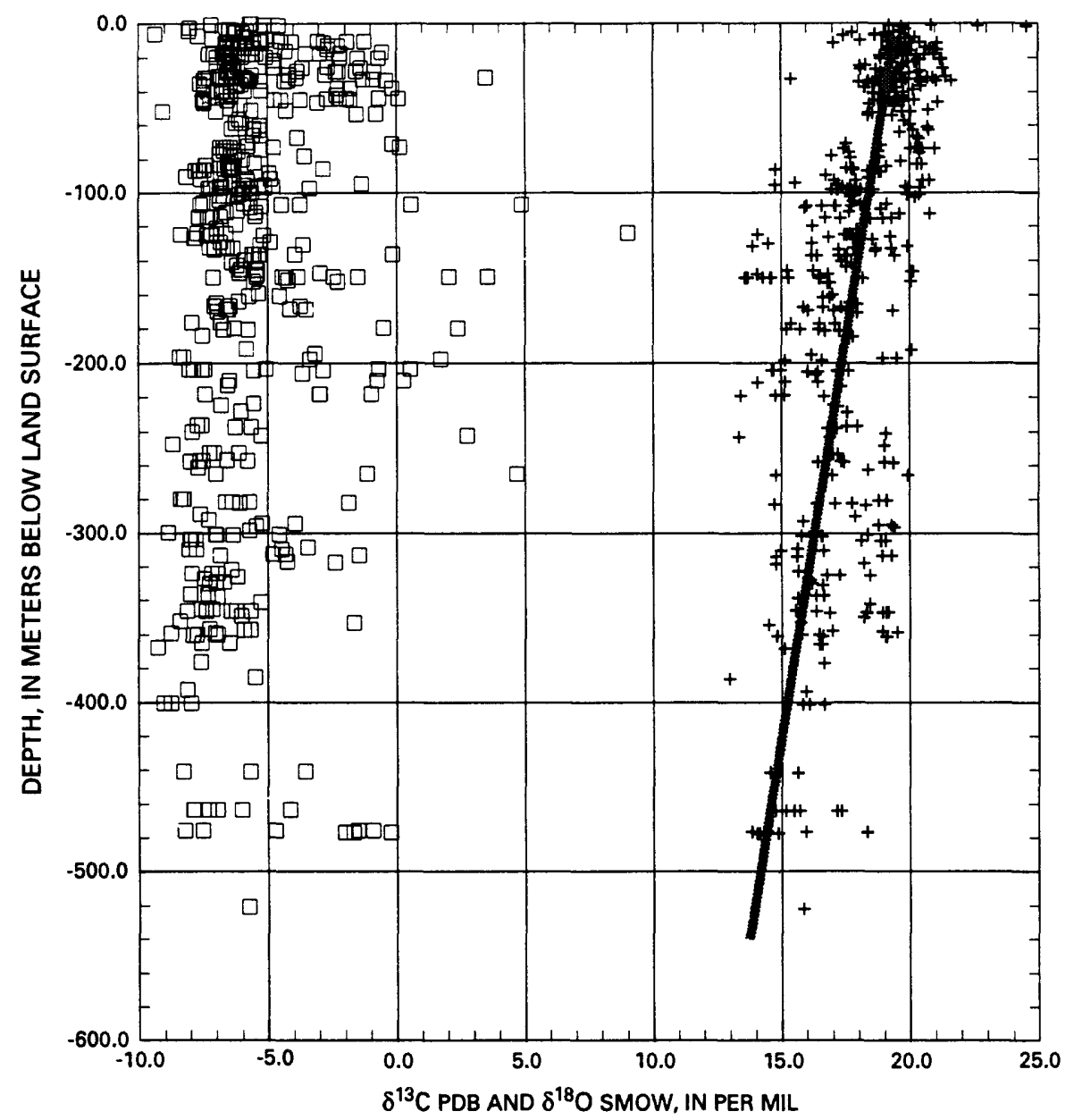

Figure 15. Plot of $\delta^{13} \mathrm{C}$ (squares) and $\delta^{18} \mathrm{O}$ (crosses) values of calcite versus depth $(\mathrm{m})$ within the unsaturated zone. The line is the predicted $\delta^{18} \mathrm{O}$ of calcite precipitated along a hypothetical geothermal gradient of approximately $34^{\circ} \mathrm{C} / \mathrm{km}$ from a fluid with a $\delta^{18} \mathrm{O}$ of about -12.5 per mil.

\section{Isotopic Geochemistry of Unsaturated-Zone Secondary Calcite}

Within the UZ, later stage calcite $\delta^{13} \mathrm{C}$ values generally are between -9 and -3 per mil (fig. 15) but range up to +8 per mil; $\delta^{18} \mathrm{O}$ values range from 12 to 21.5 per mil and display a regular decrease with depth. The $\delta^{13} \mathrm{C}$ range indicates large variations in the past carbon isotopic composition of $\mathrm{CO}_{2}$ in the soil zone. Figure 16 shows that approximately 60 percent of the $\delta^{13} \mathrm{C}$ values fall between -8 and -4 per mil, with a pronounced mode around $-6 \pm 2^{2}$. This range is essentially identical to that of calcretes on and around Yucca Mountain (J.F. Whelan, U.S. Geological Survey, written commun., 1997). Quade and Cerling (1990) concluded these calcretes formed during colder and wetter climates than today and probably are comparable to the flanks of the modern Rainier Mesa. Such values, therefore, imply calcite deposition within Yucca Mountain occurred during colder and wetter climate periods that supported increased levels of infiltration and fracture flow relative to today. Detailed microsampling of the fine laminae within Yucca Mountain may provide a $\delta^{13} \mathrm{C}$ stratigraphy linking the long-term history of plant communities to percolation and calcite deposition and, hence, insight to the history of water flux in the UZ.

${ }^{2}$ Most of the higher $\delta^{13} \mathrm{C}$ values in figure 16 probably represent mechanical mixtures of early-stage calcite, with values as high as +8 to +9 per mil, and the later stage calcite, with values near -6 per mil. 


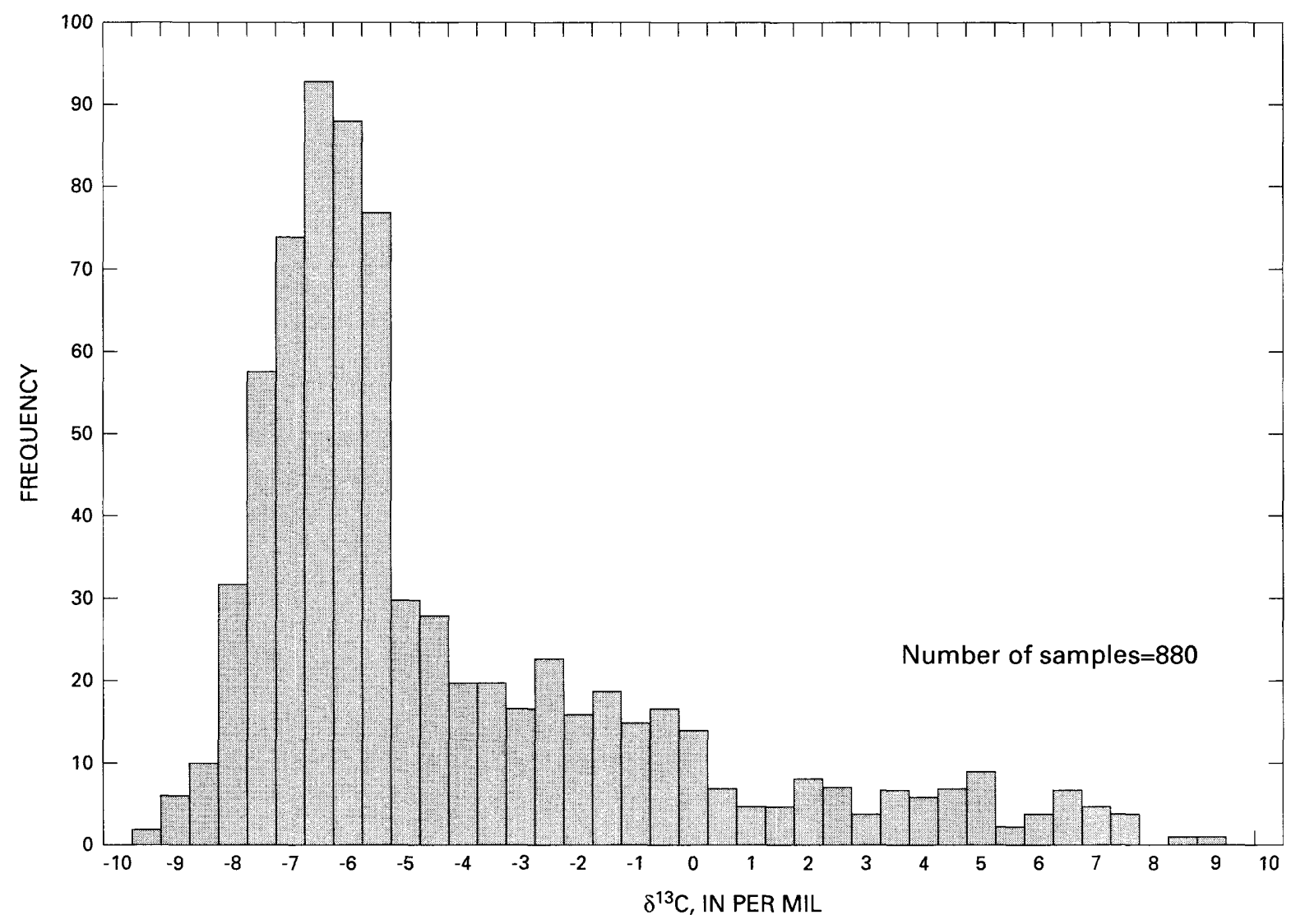

Figure 16. Distribution of unsaturated-zone secondary calcite $\delta^{13} \mathrm{C}$ values.

Unsaturated-zone calcite $\delta^{18} \mathrm{O}$ values range from about 16.5 to 21.5 per mil near the surface to about 14 to 18 per mil at the base of the UZ (fig. 15). At equilibrium, the oxygen isotopic difference between calcite and water is a function of temperature and is well known; for example, at $5^{\circ} \mathrm{C}$ this difference is about 32.6 per mil (O'Neil and others, 1969). Assuming no change in $\delta^{18} \mathrm{O}$ of percolating waters, the rate of decrease in calcite $\delta^{18} \mathrm{O}$ values is consistent with the estimated geothermal gradient of $34^{\circ} \mathrm{C} / \mathrm{km}$ (Sass and others, 1980) for the Yucca Mountain region. Past-climate-induced changes in the temperature or flux of infiltration probably would not significantly alter the geothermal gradient, so the gradient should be the same at least through the Quaternary.

The scatter of values around the predicted decrease caused by the geothermal gradient indicates significant variability in the $\delta^{18} \mathrm{O}$ of past infiltration (fig. 15). Meteoric water $\delta^{18} \mathrm{O}$ values are a function of air-mass trajectory and moisture source. Modern extremes of precipitation $\delta^{18} \mathrm{O}$ values in the Yucca Mountain region, for instance, range between arctic and continental polar air masses of about -17 to -14 per mil and maritime polar air masses of about -11 per mil (Benson and Klieforth, 1989). Modern precipitation is dominated by maritime sources (Ferrel cell) brought by the westerlies, whereas glacial climates would have proportionally more precipitation from arctic systems (Polar cell).

At $100-\mathrm{m}$ depth, $\delta^{18} \mathrm{O}$ ranges from roughly 16 to 21 per mil (fig. 15). Under the modern MAT of 14 to $15^{\circ} \mathrm{C}$, this range would precipitate from waters of -13.4 to -8.4 per mil; during glacial times and a MAT of perhaps $5^{\circ} \mathrm{C}$, the waters would have ranged from about -15.7 to -10.7 per mil. Performing the same interpolation for calcite from around $500-\mathrm{m}$ depth, which ranges in $\delta^{18} \mathrm{O}$ from about 14 to 18 per mil, predicts modern meteoric waters of -12.5 to -8.5 per mil and glacial waters of -14.5 to -10.5 per mil $^{3}$.

\footnotetext{
${ }^{3}$ Fairly good agreement between the total ranges predicted for $100 \mathrm{~m}(-15.7$ to -8.5 per mil) and $500 \mathrm{~m}(-14.5$ to -8.5 per mil) supports use of the measured geothermal gradient (Sass and others, 1980) for past reconstructions.
} 
Comparison between the calculated $\delta^{18} O$ ranges of past infiltration water and the typical $\delta^{18} \mathrm{O}$ values of modern air masses determined by Benson and Klieforth (1989) indicates that most UZ calcite has precipitated from waters derived from rain or snow produced from some mix of maritime and continental polar and arctic sources. The highest water $\delta^{18} \mathrm{O}$ values of about -8 per mil may reflect evaporation of infiltrating waters or record infiltration during a past climate with a subtropical source water, as would occur if the present summer circulation were intensified.

Climate states producing the most calcite, however, are not necessarily those producing the greatest UZ flux. Wetter climates that produced greater fluxes, but which were calcite-undersaturated and left no mineral record, are certainly possible. Additional geochronologic studies are needed to delimit those climate states conducive to calcite-depositing percolation.

\section{Conclusions}

1.Later-stage secondary calcite and opal formed from percolation of meteoric waters through the UZ and display oxygen and carbon isotopic signatures from those waters and soils. Early-stage calcites do not appear to be related to climate processes.

2.Both carbon and oxygen isotopic signatures indicate that calcite-depositing percolation occurred during climates colder and/or wetter than today-calcite-depositing climates, however, are not necessarily the wettest climate states of the past $400 \mathrm{ky}$.

3.Understanding the relation between past climates and $\mathrm{UZ}$ hydrology will be enhanced with more precise determinations of the timing of episodes of secondary mineral formation.

\section{Linkage Between Paleohydrology and Strontium Isotopes}

Strontium isotopic values are ideal solute tracers and, because strontium is chemically similar to calcium, it is a common minor element in calciumbearing minerals. Calcite $\left(\mathrm{CaCO}_{3}\right)$ and other carbonate minerals commonly incorporate and fix strontium when they precipitate from waters. Unlike isotopes of lighter elements, strontium isotopes do not fractionate significantly as a result of geochemical or biochemical processes. The pertinent strontium isotopic data will be discussed first in the SZ records and then in the surficial soil environment that influences the infiltration and $\mathrm{UZ}$ records.

Calcite mineralization provides one of the key records of paleohydrology. Secondary accumulations of calcite, in the form of spring deposits or as infillings in bedrock, are measured to determine the strontium isotope composition of the water at the time of mineral precipitation to provide information about solute sources. The strontium isotopic compositions of these calcite deposits directly record the isotopic composition of ancient waters. Dating the calcite deposits with uranium-series and radiocarbon methods provides a linkage between paleohydrological records and climate.

The strontium isotopic values in water are determined by the geology of the recharge area and, to a lesser extent, by water-rock interactions along the flow path. Once chemical equilibrium between the rock and water is established, further reactions that could change strontium isotopic values are diminished. In order to assess the variation in ${ }^{87} \mathrm{Sr} /{ }^{86} \mathrm{Sr}$ in ground water with time, samples of carbonate from Devils Hole spring (Winograd and others, 1992), which have been dated by Ludwig and others (1992), were measured. Six samples of this carbonate deposited at 650 to 180 ka show variation in ${ }^{87} \mathrm{Sr} /{ }^{86} \mathrm{Sr}$ (fig. 17; Marshall and others, 1990). This variation is most likely due to changes in the relative amounts of recharge through the variable geology at higher elevation. This example shows that strontium isotopes can vary in a flow system due to changes in climate and that the magnitude of this variation is relatively small.

\section{The Saturated Zone at Yucca Mountain and Changes in the Water-Table Position}

Fracture- and cavity-filling deposits within the volcanic rock section at Yucca Mountain commonly contain calcite. The strontium isotope compositions of these calcite deposits are plotted in figure 18. In general, the physical, chemical, and isotopic parameters of these calcites correspond to their locations within either the SZ or UZ (Marshall and others, 1992). These parameters all indicate different origins for these two groups of secondary calcite.

Present-day ground water beneath Yucca Mountain, with mean ${ }^{87} \mathrm{Sr} /{ }^{86} \mathrm{Sr}=0.7107$ (Marshall and others, 1992), cannot be the source of the strontium in the SZ secondary calcites, which contain strontium 


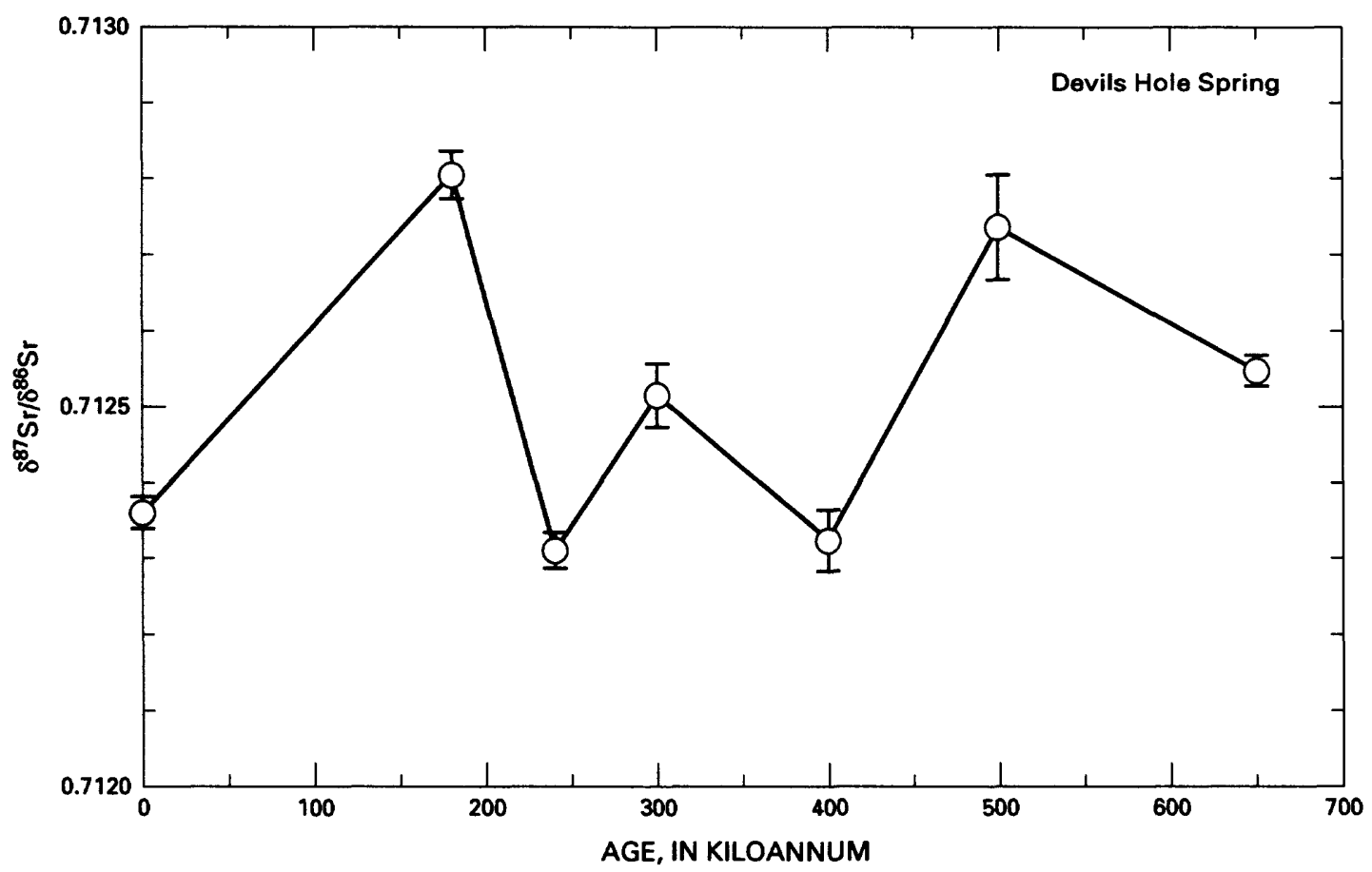

Figure 17. Strontium isotopic composition of calcite deposited at Devils Hole spring, Nevada, plotted as a function of age. The zero age point is the composition of the current discharge. The total range of strontium-87/86 shown here is much smaller than the range of any sample groups.

with an isotopic composition characteristic of Paleozoic carbonate rocks ${ }^{87} \mathrm{Sr} /{ }^{86} \mathrm{Sr}=0.708$ to 0.709 ; fig. 18). These values imply water from the deeper regional carbonate aquifer penetrated upward into the volcanic rock section, probably early in the history of the volcanic rocks, and deposited calcite. There are currently no reliable age data to support or refute this hypothesis for the origin of the $\mathrm{SZ}$ calcites.

Discharge sites active within the Quaternary are found about $20 \mathrm{~km}$ southwest of Yucca Mountain, indicating that the water table (or a perched table) was at the surface in the past (Paces and others, 1993; see also discussion below under Past Ground-Water Discharge). Strontium isotope compositions $\left({ }^{87} \mathrm{Sr} /{ }^{86} \mathrm{Sr}\right.$ $=0.713$ ) of carbonate from these sites are fairly atypical for the Yucca Mountain area (Marshall and others, 1993), but those values are known from one well in Crater Flat.

Today, the water table is about $100 \mathrm{~m}$ below ground surface near the past discharge sites. Because the discharge sites are most likely the result of a regional water-table rise, the water table would also have been higher at Yucca Mountain when the discharge sites were active. There are multiple lines of evidence pertaining to a higher water table at Yucca Mountain (Marshall and others, 1993). Eighty-five meters above the water table, the UZ secondary calcite contains strontium with an isotopic composition similar to present-day ground water. Although these calcite samples are not unique in other parameters, their strontium isotope ratio is indicative of an origin unlike that of the bulk of the UZ calcite. The strontium data clearly indicate distinct origins for the $\mathrm{UZ}$ and $\mathrm{SZ}$ calcites and indicate that the present water-table position may have been approximately $85 \mathrm{~m}$ higher in the recent past in order to explain the ${ }^{87} \mathrm{Sr} /{ }^{86} \mathrm{Sr}$ values of the four $\mathrm{G}-2$ samples from the $\mathrm{UZ}$.

Perched water has been encountered in many boreholes at Yucca Mountain. It contains strontium with an isotopic composition identical to that in the pedogenic calcite discussed below (Marshall and others, 1994). Therefore, the perched water is not a remnant of an ancient higher water table. The perched water is probably locally derived during times of higher infiltration than the present day. 


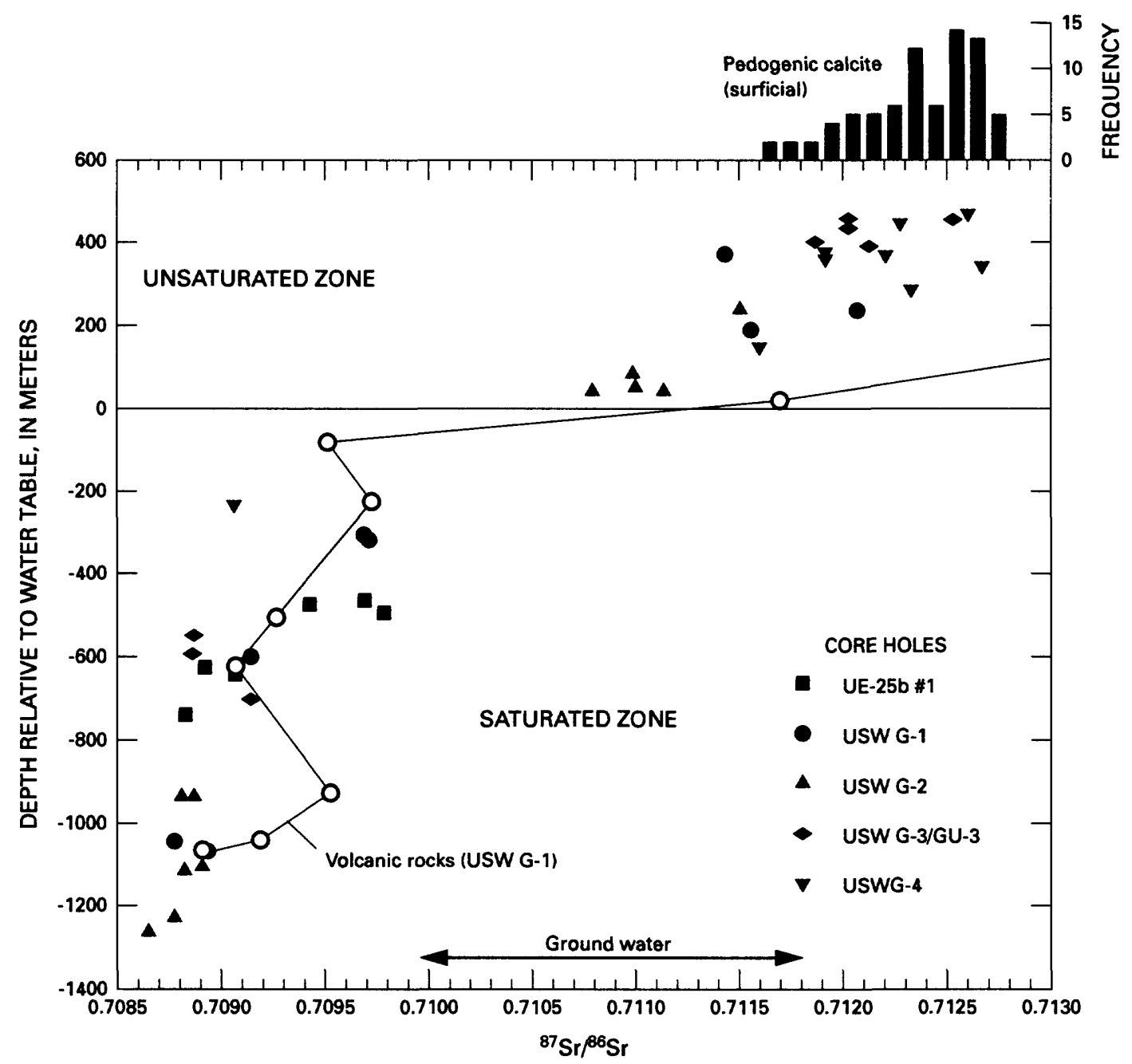

Figure 18. Strontium-87/86 ratios in calcites from various core holes as a function of depth relative to the depth of the water table in the core holes sampled. The histogram at top shows the range of data for pedogenic calcites. Composite samples of the volcanic rocks from borehole USW G-1 are shown for comparison. The range of ${ }^{87} \mathrm{Sr} /{ }^{86} \mathrm{Sr}$ values in ground water in the vicinity of Yucca Mountain, Nevada, is shown by the double-headed arrow at bottom.

\section{Pedogenlc Calclte at Yucca Mountaln}

Calcite is present in the surficial environment in the form of coatings on bedrock surfaces, calcretes within soil horizons, and vein calcretes within fault zones. Ultimately, all of these occurrences of calcium carbonate derive their calcium primarily from an eolian source (Marshall and Mahan, 1994). Porous sediments in soils of arid and semiarid regions usually require an allogenic component for the source of the large amounts of calcium carbonate (Machette, 1985). Strontium isotopes in calcic soil horizons (K horizons) obtained from calcretes and rhizoliths have values of ${ }^{87} \mathrm{Sr} /{ }^{86} \mathrm{Sr}(0.7117$ to 0.7127$)$ that are virtually identical to those of calcite in eolian sediments, surface coatings, and soil A/B horizons. Therefore, the model proposed for the pedogenic carbonate (fig. 19) starts with the eolian component as an end-member composition. However, there are two problems with this hypothesis: (1) The samples taken as typical of eolian materials may be poor proxies for the dust flux today or in the recent past, and (2) only a few materials exist with more radiogenic ${ }^{87} \mathrm{Sr} /{ }^{86} \mathrm{Sr}$ required to explain the strontium values of the pedogenic calcite. Analysis of pedogenic carbonate silicate residues and comparison with the ${ }^{87} \mathrm{Sr} /{ }^{86} \mathrm{Sr}$ values of the volcanic rocks in the Yucca Mountain area did not reveal the more radio- 


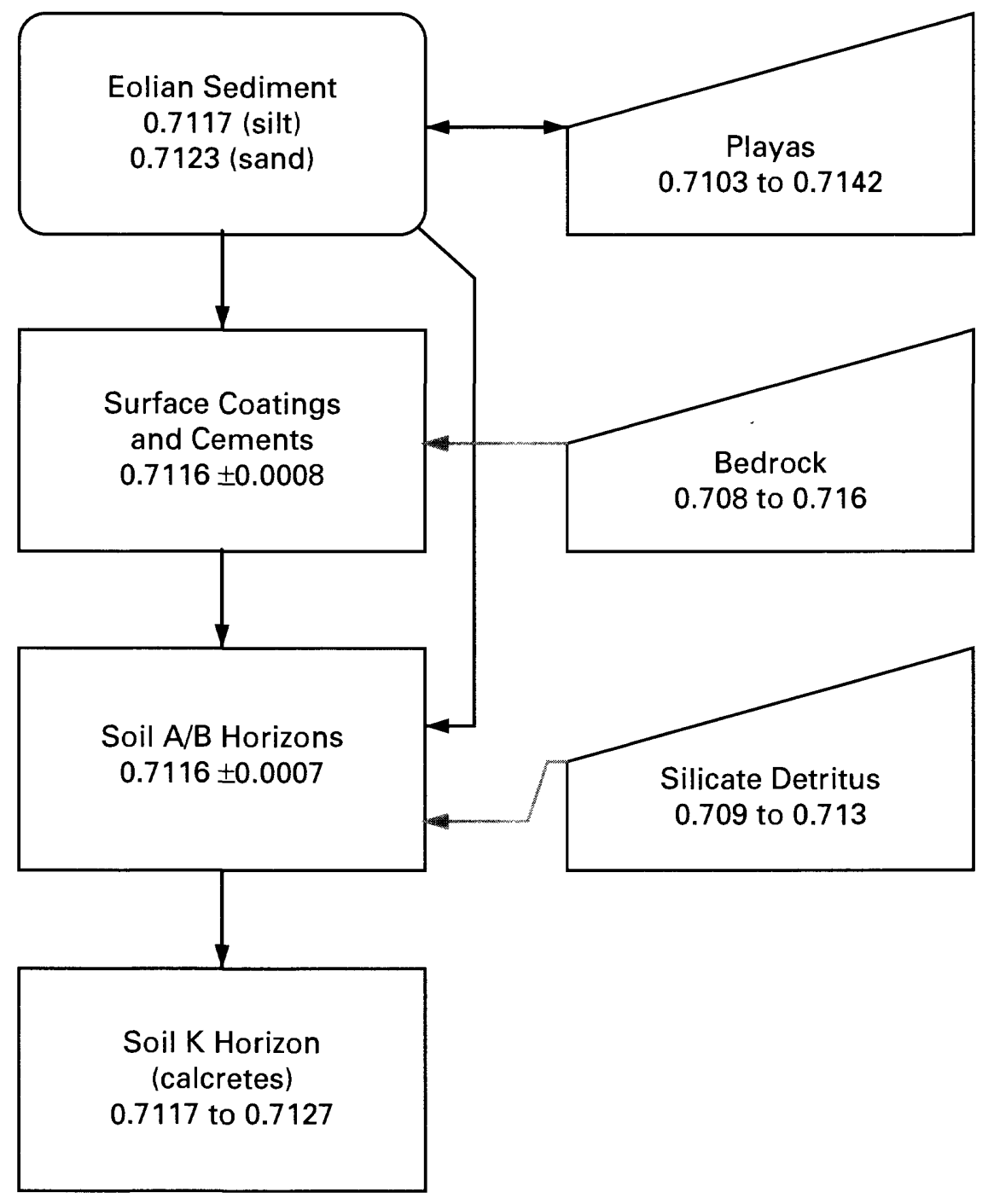

Figure 19. Box model for the strontium data in the pedogenic carbonate system. Ranges for ${ }^{87} \mathrm{Sr} /{ }^{86} / \mathrm{Sr}$ are shown in each box (see text for discussion). The lighter gray arrows indicate lesser contributions for some components. Silicate detritus is the leached residue from calcic soil samples.

genic source needed for the other end member. Local volcanic surface rocks do have more radiogenic strontium but also have low strontium concentrations, requiring a large amount of material be weathered and leached to contribute significantly to the strontium in the pedogenic carbonate. It is possible that plants growing on the volcanic soil can concentrate these dilute sources of radiogenic strontium.

The model currently hypothesized is best represented by the box diagram shown in figure 19. Playas may be sinks for, or sources of, eolian sediment dominated by silt-size carbonate, depending on climate. The eolian sediment directly forms surface coatings on bedrock and cements sediments in channels by solution and reprecipitation; it also is incorporated into soils and may form the notable K-horizon calcretes over time. The surface coatings also may contribute carbonate to soils during runoff events. Bedrock and even local silicate detritus contribute only minor amounts of calcium to the secondary carbonates. Future studies on the playas and past climate may help to eliminate the uncertainties in the model. Nonetheless, the variability and mass-balance issues described here appear to provide a record of site-scale climate activity that differs from the modern climate. 


\section{Unsaturated-Zone Fracture FIIIIngs}

Strontium isotope ratios of the UZ fracture calcite are plotted relative to the depth of the water table in figure 18; analyses of the pedogenic calcite discussed above are shown as a histogram at the top of the figure. It is evident that the bulk of the UZ fracture calcites derive their strontium from pedogenic carbonate exposed at the surface. The decrease in ${ }^{87} \mathrm{Sr} /{ }^{86} \mathrm{Sr}$ values with depth in the $\mathrm{UZ}$ may reflect an increasing input from volcanic feldspar with depth, that is, the lowest ${ }^{87} \mathrm{Sr} /{ }^{86} \mathrm{Sr} \mathrm{UZ}$ ratios derive most of their strontium from pore water in the tuff. The UZ secondary calcite and opal, thus, are directly related to surficial deposits that, similar to the stable isotopes, demonstrate the existence of surface-derived percolation within the UZ, presumably as a function of climate change.

\section{Conclusions}

1. Strontium isotopes are an ideal tracer of the solute sources in surface and ground waters and are a common component of calcite.

2. Strontium in ground water can vary in its isotopic ratio over time but within a limited range.

3. Calcite fracture/cavity fillings within the $S Z$ at Yucca Mountain are probably very old and are not in Sr isotopic equilibrium with present-day ground water.

4. Calcite deposited at past discharge sites has a distinct $\mathrm{Sr}$ isotopic composition that can be linked to ground water at Crater Flat.

5. There is evidence for an extension to Yucca Mountain of the ancient higher water table that existed at the discharge sites.

6. Perched water has a $\mathrm{Sr}$ isotopic composition consistent with derivation from local infiltration rather than an older, higher water-table stand.

7. In general, calcite in soils and within the $\mathrm{UZ}$ is consistent with derivation from eolian sources, but evidence shows that these sources may vary in time, possibly reflecting different past climates.

8. Unsaturated-zone fracture fillings record infiltration and percolation of surface water that obtained $\mathrm{Sr}$ from soil carbonate. There is little evidence for interaction with the volcanic rocks.

\section{Geochronologic Studies of Calcite and Opal Deposits in the Exploratory Studies Facility}

\section{Introduction}

A key remaining issue in determining the suitability of Yucca Mountain for the construction of a potential nuclear-waste repository centers on the past, present, and future water flux through the repository block. Characterization and understanding of the modern UZ hydrologic system is critical to the flux issue, but no matter how complete this understanding, it is but an instantaneous hydrogeologic observation in a temporal continuum of change. Therefore, deciphering the paleohydrology of the $\mathrm{UZ}$ is requisite to understanding how water fluxes may vary in the future in response to climate change. Fortunately, mineralogical records of past percolation exist in the rock mass, and these can be used to estimate fluxes by establishing a statistically and spatially valid distribution of ages of these minerals.

Low-temperature secondary minerals, notably calcite $\left(\mathrm{CaCO}_{3}\right)$ and opal $\left(\mathrm{SiO}_{2} \cdot \mathrm{nH}_{2} 0\right)$, were deposited in open fractures and cavities in the volcanic rocks at Yucca Mountain by water percolating downward through the UZ over long periods of time. Through their contained radioactive clocks ${ }^{14} \mathrm{C}$ and U-series disequilibrium isotopes, the depositional history of these minerals can be established. Calcite also contains isotopic records $(\mathrm{O}, \mathrm{C}$, and $\mathrm{Sr})$ that link infiltration and depositional history with climatic variations at the surface; these data are discussed elsewhere in this report. The spatial and temporal distribution of isotopic ages, coupled with estimates of the abundance and spatial variability of calcite and opal in the Exploratory Studies Facility (ESF), will be used to estimate the flux required to produce this physical record of percolation. An understanding of how the flux responds to changing climatic conditions at the surface will be developed from both the resulting temporal framework and from the isotopic records contained within calcite. Lack of correlation between the depositional (or dissolutional) history of the subsurface mineral records and changing climate would testify to the long-term stability of a system that was effectively buffered from external hydrological forcing factors (Chapman and McEwen, 1993).

The incorporation of uranium and the virtual exclusion of thorium from both calcite and opal when 
they precipitate from water is the basis for U-series dating of these materials. As water infiltrates through the soil zone, it dissolves $\mathrm{CO}_{2}$, which contains ${ }^{14} \mathrm{C}$; the carbon is included in the calcite when it precipitates. Once sequestered into the calcite and opal, the decay of these radioactive isotopes is the basis for determining the times of deposition.

Interpretation of the ${ }^{14} \mathrm{C}$ ages is further complicated by water/gas solid/interactions moving from the soil-zone source to depth. Some of the ${ }^{14} \mathrm{C}$ dissolved in the water decays during percolation from the soil zone to the site of calcite precipitation. In addition to the incorporation of modern carbon, infiltrating waters also very likely acquire dead carbon from dust or calcrete deposits at the surface, which, in its maximum effect, results in a one half-life error for the resulting radiocarbon activity. Both failure to account for a long ground-water travel time and the inheritance of dead carbon could result in ${ }^{14} \mathrm{C}$ ages of calcite that are too old. The third complication with ${ }^{14} \mathrm{C}$ ages results from the possible incorporation of modern carbon from $\mathrm{CO}_{2}$ in air circulating through fractures in the rock mass. For the latter mechanism to be important, however, water must be present and it must have a low dissolved inorganic carbon (DIC) content to allow for a meaningful exchange of gaseous ${ }^{14} \mathrm{C}$ with the DIC pool. The magnitude of these effects on the determined ${ }^{14} \mathrm{C}$ ages is presently not known. The mere presence of detectable ${ }^{14} \mathrm{C}$ in a sample implies formation of calcite within the last $40 \mathrm{ka}$, even if exact ages cannot be determined.

A parallel study also aimed at developing a better understanding of past water flux is being conducted by Los Alamos National Laboratory using chlorine-36 $\left({ }^{36} \mathrm{Cl} / \mathrm{Cl}\right)$ measurements (J. FabrykaMartin, A.V., Wolfsberg, P.R., Dixon, S., Levy, J., Musgrave, and H.J., Turin, Los Alamos National Laboratory, written commun., 1996). Salts, formed by the evaporation of pore water, are extracted by leaching with deionized water, and the ${ }^{36} \mathrm{Cl} / \mathrm{Cl}$ ratios are measured by accelerator mass spectrometry.

\section{Sampling and Analyses}

The ESF provides a unique opportunity to study and sample calcite and opal deposits in the potential repository rock mass. Delicate crystal forms are well preserved in both lithophysal cavities and in open fractures. Such features were not seen in drill core, apparently because they were destroyed during the drilling process.
Ninety-six samples of calcite and opal collected between the North Portal and Station 40 ( $4 \mathrm{~km}$ into the tunnel) have been dated by the U-series method through the end of July 1996. Thirty-one samples of calcite collected between Stations 13 and 36 have been dated by the ${ }^{14} \mathrm{C}$ method. The U-series analyses were determined by thermal ionization mass spectrometry, as described by L.A. Neymark, and J.B., Paces, (U.S. Geological Survey, written commun., 1995). Measurements of ${ }^{14} \mathrm{C}$ were determined by accelerator mass spectrometry.

\section{Analytical Data}

Calcite and opal form complex associations at both megascopic and microscopic scales. Detailed descriptions of the deposits and paragenetic interpretations were made (Paces, 1996). Textures show, unequivocally, that depositional growth typically progressed outward into open space, so the outermost layers form the youngest parts of the deposits.

Because percolation during the past several thousands of years is thought to be most relevant to future waste isolation, the dating study has emphasized, with some exceptions, the outermost layers of the deposits.

Because of potentially low depositional rates, microsampling was conducted with dental tools and small grinders under a microscope to acquire a sample representing a minimal stratigraphic thickness. Even with this fine-scale sampling approach, the samples likely do not represent finite growth or depositional intervals (J.B. Paces, U.S. Geological Survey, written commun., 1996). Sampling resolution ultimately is limited by analytical requirements of 10 to $20 \mathrm{mg}$ of calcite for ${ }^{14} \mathrm{C}$ analyses, whereas U-series analysis requires 50 to $100 \mathrm{mg}$ of calcite and 0.1 to $2 \mathrm{mg}$ of opal. The very small sample size required for opal is a result of relatively large $U$ contents (typically 50 to $200 \mathrm{ppm}$ ). The net effect of sampling over multiple growth layers is that the determined ages $\left({ }^{230} \mathrm{Th} / \mathrm{U}\right.$ and ${ }^{14} \mathrm{C}$ ) will be biased somewhat toward the young side of the true mean age of the material. Where multiple subsamples have been taken from a single sample, the isotopic ages are consistent with relative ages established from mineral relations. The age data also clearly demonstrate that these occurrences formed by very slow depositional rates on the order of micrometers per thousands of years. 


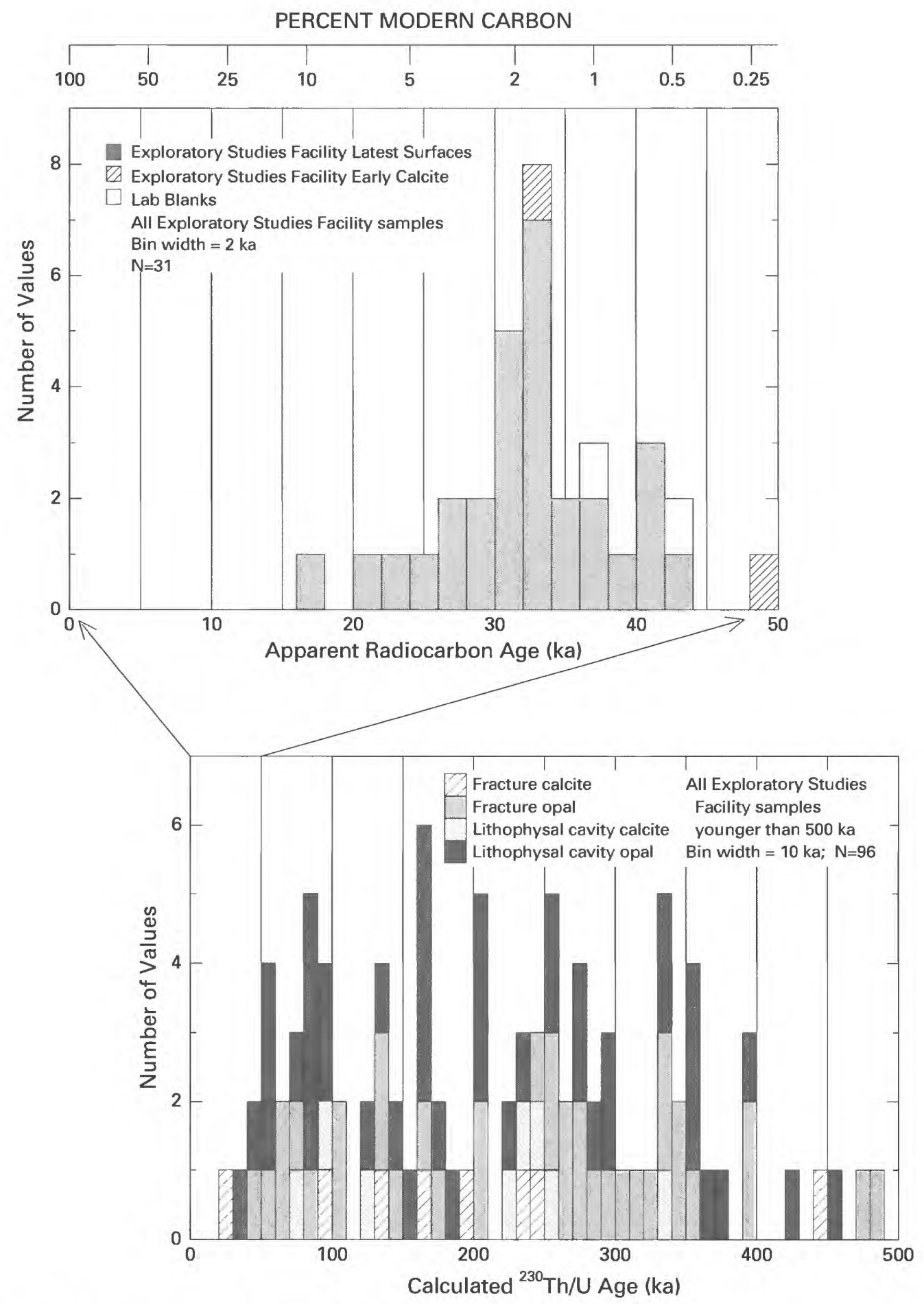

Figure 20. Histograms of apparent radiocarbon and ${ }^{230} \mathrm{Th} / \mathrm{U}$ ages determined from calcites and opals from the Exploratory Studies Facility, Yucca Mountain, Nevada. Note tenfold difference in age scale between upper and lower histograms. Most age determinations are from materials representing outermost growth surfaces. Data have been interpreted to represent very slow rates of mineral deposition (J.B. Paces, written commun., 1996), with the possibility of mechanical mixing between younger and older components within a single analysis. 


\section{Distributions of Ages and Correlation with Climate Cycles}

The distributions of ${ }^{14} \mathrm{C}$ ages and $\mathrm{U}$-series ages are shown on figure 20. One sample of Paleozoic limestone submitted as a blank yielded approximately 1 percent modern carbon and an apparent age of $37 \mathrm{ka}$. Until further analyses are completed, ages greater than $37 \mathrm{ka}$ should be considered infinite. Except for two samples, the ${ }^{14} \mathrm{C}$ ages represent an attempt to date the latest growth surfaces. The youngest age determined is $16 \mathrm{ka}$, and a peak between 35 and $30 \mathrm{ka}$ is evident (fig. 20). That peak coincides with one of the wettest episodes in the region according to interpretations given above under terrestrial records. However, a secondary peak from 30 to $27 \mathrm{ka}$ coincides with a relative dry period in the region, and another very wet period from 23 to $21 \mathrm{ka}$ has only one value. Perhaps this pattern simply illustrates complicating ${ }^{14} \mathrm{C}$ factors, described above, or perhaps it shows that the UZ was buffered from surface climate processes, or it may simply identify the need for additional samples.

Because of the much larger samples of calcite required for U-series dating, approximately five times as much, the age resolution is more limited, and the potential for bias from the mean age of the sampled material is greater. Much smaller samples of opal can be dated, thus providing U-series age resolution comparable to that of ${ }^{14} \mathrm{C}$ in the interval up to $100 \mathrm{ka}$.

The distribution of U-series ages is shown on figure 20. The data are categorized according to mineralogy (calcite or opal) and by occurrence (fracture or cavity). It is evident from the distribution of ages so categorized that there are no apparent biases or differences based on occurrence or mineralogy. The youngest age thus far determined is $27 \mathrm{ka}$ on calcite from a fracture, and the oldest ages within the $500 \mathrm{ka}$ range (which is the approximate limit of the technique) are on opal at 470 and $480 \mathrm{ka}$. On the assumption that any age bias resulting from sampling material deposited over finite time intervals is minimal, a correlation between age distribution (time of mineral deposition) and climatic cycles might be expected. Proof of such a correlation will require a statistically valid number of age determinations in order to delineate clearly depositional and nondepositional episodes should they exist.

When the ESF dating study has been completed through the southern part of the main drift and through the south ramp, the geochronologic data base should be sufficiently large for a reliable assessment of climatic correlation. Visual inspection of the age distribution indicates a weak correlation with climate cycles. Calcite or opal ages younger than 27 to $17 \mathrm{ky}$ old have not been determined. Numerically, there appear to be data gaps at 17 to $0 \mathrm{ka}, 120$ to $100 \mathrm{ka}$, and 220 to $210 \mathrm{ka}$, and the interval 330 to $300 \mathrm{ka}$ contains only one age for each 10,000 years. Perhaps fortuitously, these apparent gaps in ages occur during interglacial periods. Documenting whether or not such correlations between mineral deposition and climate cycles are real is one of the main goals of the isotopic dating study. A close correlation between mineral deposition and climate cycles would indicate a fast response of the $\mathrm{UZ}$ hydrologic system to climate forcing. Consideration would need to be given to response of the UZ to particular climate cycles. As noted under the discussion of long records, OIS stages 6 (about 170 to $140 \mathrm{ka}$ ) and 2 (about 25 to $15 \mathrm{ka}$ ) are the wettest, but the region's future will likely be more similar to OIS 10 (about 400 to $350 \mathrm{ka}$ ). In contrast, a poor correlation would indicate a highly buffered system that has responded in a sluggish fashion to external climate forcing.

\section{Past Ground-Water Discharge and Late Pleistocene Fluctuations in Water-Table Elevations}

Past-climate proxy records from throughout the southern Great Basin clearly demonstrate that episodes of higher effective moisture relative to present-day conditions were resident about 70 to 80 percent of the time during the last 2 million years. An understanding of how increased amounts of surface water translate to ground-water dynamics is of great importance to the issue of radioactive waste isolation in the potential geological repository at Yucca Mountain.

The potential repository horizon is located approximately 200 to $400 \mathrm{~m}$ above the present-day water table. However, evidence for higher SZ water levels at some time in the past has been derived from secondary mineral occurrences (Levy, 1991) and Sr isotopic variations (Marshall and others, 1993) from borehole data, and from hydrologic models involving increased recharge (Czarnecki, 1985) in the Yucca Mountain regional flow system. Although evidence from these studies indicates a maximum increase in water-table elevation of 100 to $150 \mathrm{~m}$, the age of these fluctuations remains unconstrained. 
Determining the maximum extent and timing of water-table fluctuations is an important aspect of estimating the possible range of SZ conditions beneath Yucca Mountain over the next several glacial cycles. In addition, dated records of water-table fluctuation provide information on how rapidly ground-water hydrologic systems responded to changes in Pleistocene climate and indirectly may delineate changes in areas of significant recharge, flow paths, and travel times.

Sparse vein minerals from drill cores provide geological evidence for SZ water fluctuations at Yucca Mountain. Ground-water discharge deposits, however, are commonly exposed in southern Crater Flat and the central Amargosa Valley. These surface deposits are downgradient from and within 15 to $20 \mathrm{~km}$ to central Yucca Mountain. Several of these deposits have received preliminary study to determine the timing, nature, and source of past discharge, so the relations between climate and $\mathrm{SZ}$ response can be evaluated (J.B. Paces and others, U.S. Geological Survey, written commun., 1996).

\section{General Geologic Relations}

Paleodischarge deposits (fig. 21) include the Crater Flat deposits, Crater Flat Wash deposits, Lathrop Wells Diatomite deposit, State Line deposits, and Indian Pass deposits. Active discharge areas are more spatially restricted but include the high-volume springs at Ash Meadows and in Death Valley, as well as wide-spread seepage discharge at Franklin Lake Playa. All of these paleodischarge deposits have lowlying, badland-type morphologies with lithologies dominated by whitish-gray to pale-green, sand- and silt-rich detritus. Coarse clastic material is conspicuously absent, a feature that readily distinguishes them from alluvial and colluvial deposits associated with surface-water transport (Quade and others, 1995). Bedding is typically massive, punctuated by laterally discontinuous layers of authigenic materials such as carbonate-rich nodules or mat-like layers containing casts of insect burrows or plant petrifactions. Authigenic calcite and lesser silica produce a wide range of cementation from soft, barely calcareous silt to contorted hard nodules to dense limestone containing regularly spaced, subvertical tube-like voids (probably plant-stem molds). Much of the layered or nodular limestone typically contains fine-grained siliciclastic material (clays), which complicates ${ }^{230} \mathrm{Th} / \mathrm{U}$ geochro- nologic interpretations. A 1- to 2-m-thick bed of white to whitish-gray diatomite is unique to the Lathrop Wells Diatomite deposits. Plant petrifactions, mollusc shells, ostracodes, vertebrate fossils, and Native American artifacts are known at most sites. More laterally extensive, but similar-appearing, deposits flank the nearby Spring Mountains, southeast of the Nevada test site. These deposits were interpreted as eolian detritus captured by vegetation associated with wet, marshy ground or small, open-water bodies, along with authigenic minerals deposited from calcium- and silica-rich ground waters (Quade and others, 1995).

\section{Geochronological Data}

Ground-water deposits were variously dated by three geochronological techniques. Uranium-series disequilibrium dates were obtained from authigenic carbonate and plant petrifaction silica, nodules, limestone layers, carbonate-rich insect burrow casts, and mollusc shells. Radiocarbon dates were obtained from mollusc shells and carbonate plant petrifactions. Thermoluminescence (TL) dates come from polymineralic silt-sized components separated from fine-grained, noncemented loamy units.

The greatest number of age determinations come from uranium-series disequilibrium. Resulting ages range from about 240 to $11 \mathrm{ka}$, well below the upper limit ( 500 to $350 \mathrm{ka}$ ) of the method. The detectable upper age limit is determined, in part, by the initial ${ }^{234} \mathrm{U} /{ }^{238} \mathrm{U}$ ratio, where the higher the initial ratio, the older the detectable age. The detectable upper age limit also is a function of the analytical precision, where the better the precision, the smaller the error range and the greater the ability to resolve older ages. Young ages are more common due to those materials being readily accessible at the surface. Ages, shown in figure 22, are plotted against the calculated initial ${ }^{234} U /{ }^{238} U$ (value of ${ }^{234} U /{ }^{238} U$ in the discharge water at the time of mineral formation). No systematic trend of initial ${ }^{234} \mathrm{U} /{ }^{238} \mathrm{U}$ versus age is apparent in these data. Indeed, nearly the entire range of initial ${ }^{234} \mathrm{U} /{ }^{238} \mathrm{U}$ variation, from approximately 3 to 4.5 , is observed in the youngest materials ( 20 to 10 ka). The wide range of calculated initial ${ }^{234} U /{ }^{238} U$ is interpreted to reflect real variations in water compositions during the latest episodes of discharge. Uniform calculated initial ${ }^{234} U /{ }^{238} U$ for samples with older ages provides an internal check of the accuracy of the ${ }^{230} \mathrm{Th} / \mathrm{U}$ ages. 


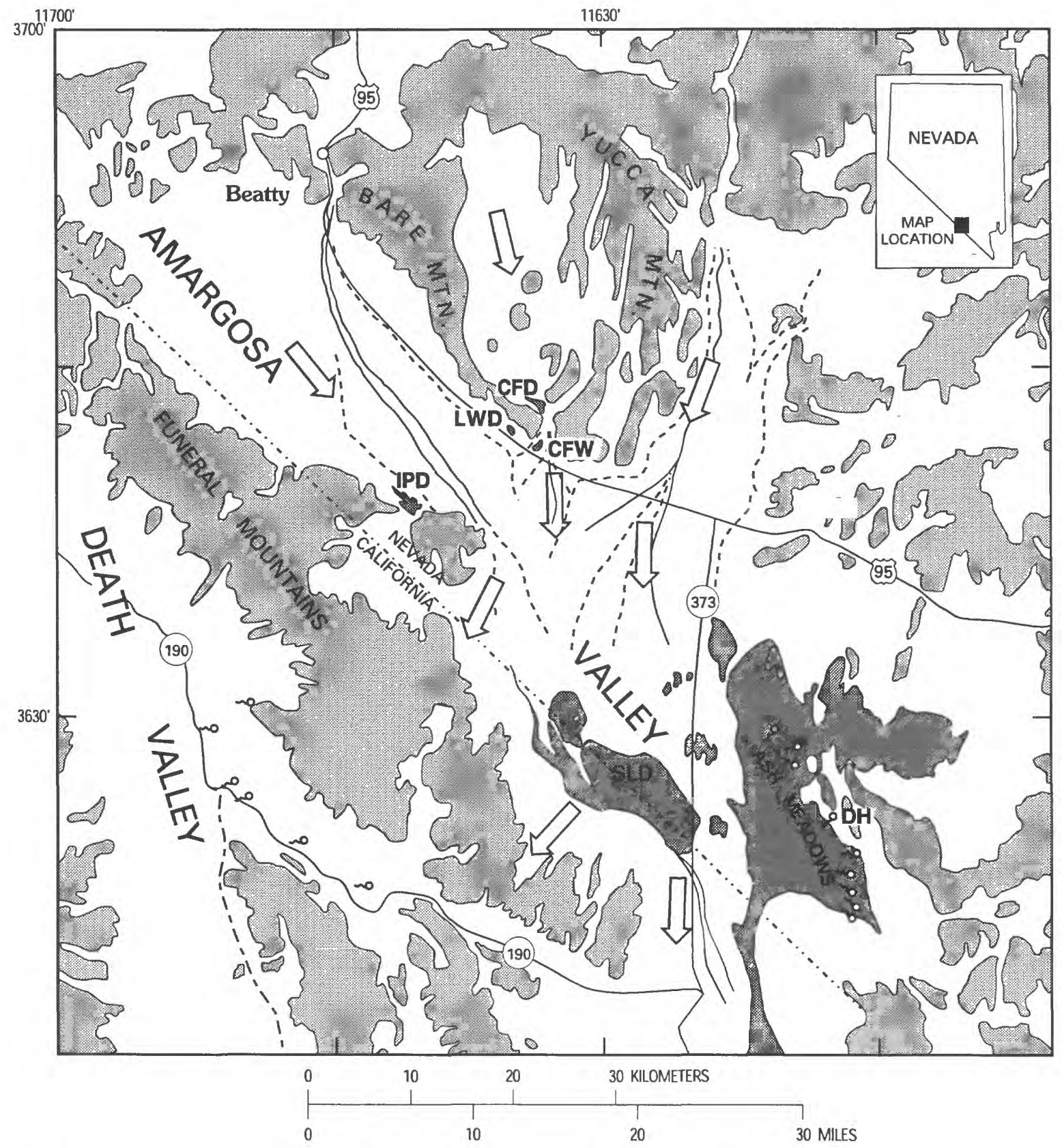

Figure 21. Paleodischarge deposits [dark-shaded patches with $\mathrm{CFD}=$ Crater Flat Deposits, $\mathrm{CFW}=$ Crater Flat Wash, $\mathrm{DH}=$ Devils Hole, LWD = Lathrop Wells Diatomite, IPD = Indian Pass Deposits, SLD = State Line Deposits in the Yucca Mountain region, Nevada. Active springs at Ash Meadows and Death Valley are shown with spring symbols. Outlined arrows show generalized ground-water flow paths. Light-shaded polygons represent bedrock highs; intervening unpatterned areas represent alluvium-filled basins. Solid and dashed lines in basins represent fluvial channels and fan boundaries, respectively. 


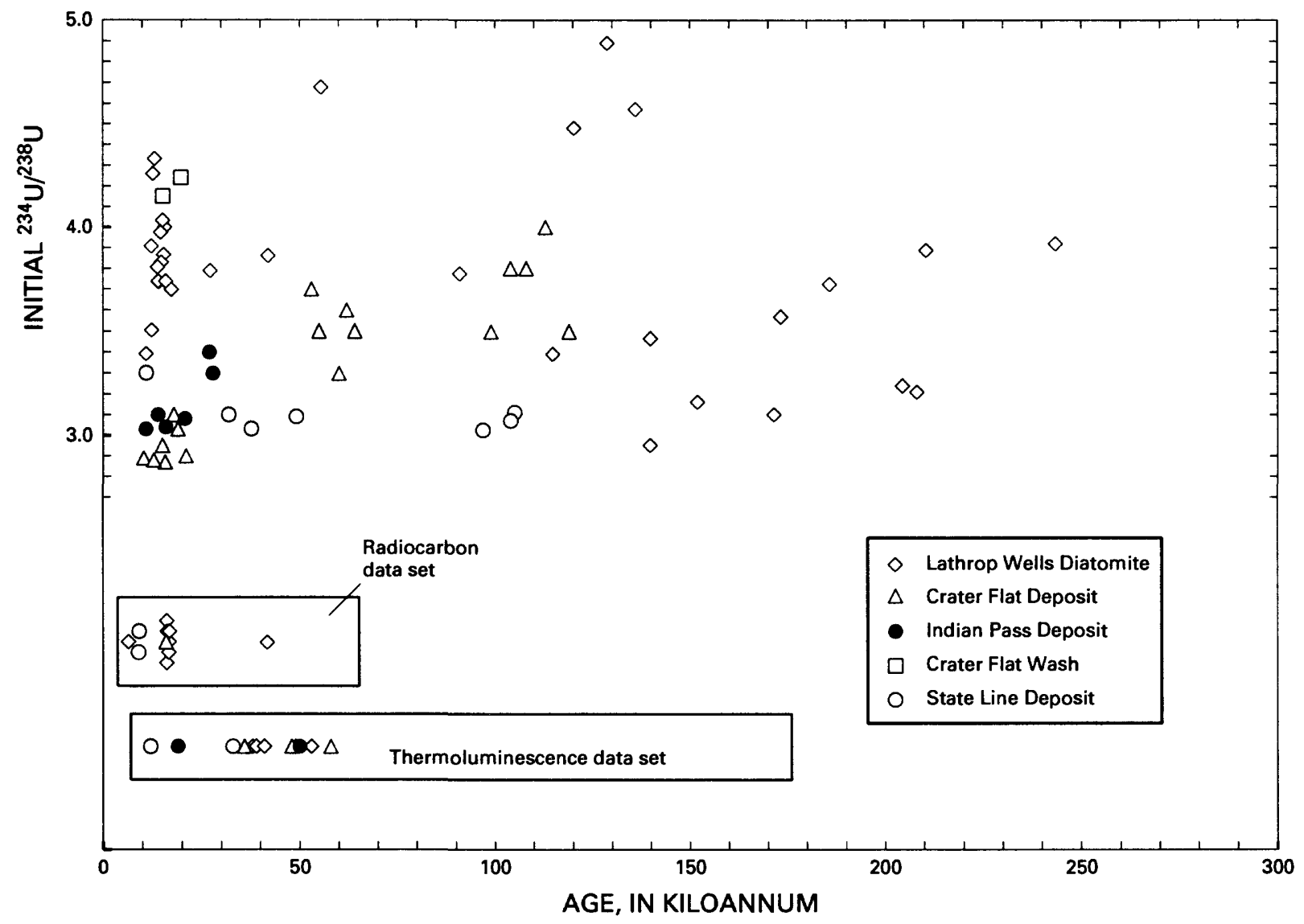

Figure 22. Ages determined by ${ }^{230} \mathrm{Th} / \mathrm{U}$, radiocarbon, and thermoluminescence methods for samples from paleodischarge sites in the Yucca Mountain, Nevada, region. Data are grouped by locations given in figure 1. Data in upper portion of diagram are ${ }^{230} \mathrm{Th} / \mathrm{U}$ ages plotted against calculated initial ${ }^{234} \mathrm{U} /{ }^{238} \mathrm{U}$. The lower two data sets, representing radiocarbon ages and thermoluminescence ages, are shown at the same age scale but do not carry information regarding vertical position.

The radiocarbon data set was obtained principally from well-preserved molluscs from selected horizons as well as from several uranium-series disequilibrium-dated calcareous rhizoliths. Although aquatic molluscs may incorporate dead carbon from aquifer bicarbonate (Riggs, 1984), terrestrial molluscs commonly utilize atmospheric carbon, potentially providing more reliable ages than their aquatic counterparts (Brennen and Quade, 1995).

Mollusc shells collected near the top of the Lathrop Wells Diatomite deposits yield corrected radiocarbon ages of 14.1 to $13.5 \mathrm{ky}$ before present that when calibrated to calendar years (Stuiver and Reimer, 1993) cluster between 16.9 to $16.2 \mathrm{ka}$ for terrestrial and aquatic species of snails. This horizon also contains plant petrifactions with overlapping ${ }^{230} \mathrm{Th} / \mathrm{U}$ ages between 16.0 and $13.9 \mathrm{ka}$. Mollusc shells from near the base of the exposed Lathrop Wells Diatomite deposits have radiocarbon ages between 42 and $36 \mathrm{ka}$. In contrast, correlation of this horizon to other parts of the section indicates uranium-series disequilibrium ages between 180 to $130 \mathrm{ka}$. The modern-carbon percentage for these ages is low, 0.5 to 1.0 percent, so, despite care in specimen selection, these dates may, in fact, be infinite. A sample of paleozoic limestone also dated about $37 \mathrm{ka}$ (see distribution of ages and correlation with climate cycles above). Carbonates of different ages are often mixed in spring deposits (J.B. Paces, U.S. Geological Survey, written commun., 1995). Radiocarbon mollusc dates from State Line deposits gave $9 \mathrm{ka}$ for terrestrial snails and $11 \mathrm{ka}$ for an aquatic snail. These ages fall within uncertainty of a single ${ }^{230} \mathrm{Th} / \mathrm{U}$ determination of $11 \pm 2 \mathrm{ka}$ from one aquatic snail, as well as a TL age estimate of $13 \pm 2 \mathrm{ka}$ determined from the silt fraction in the same sediment. 


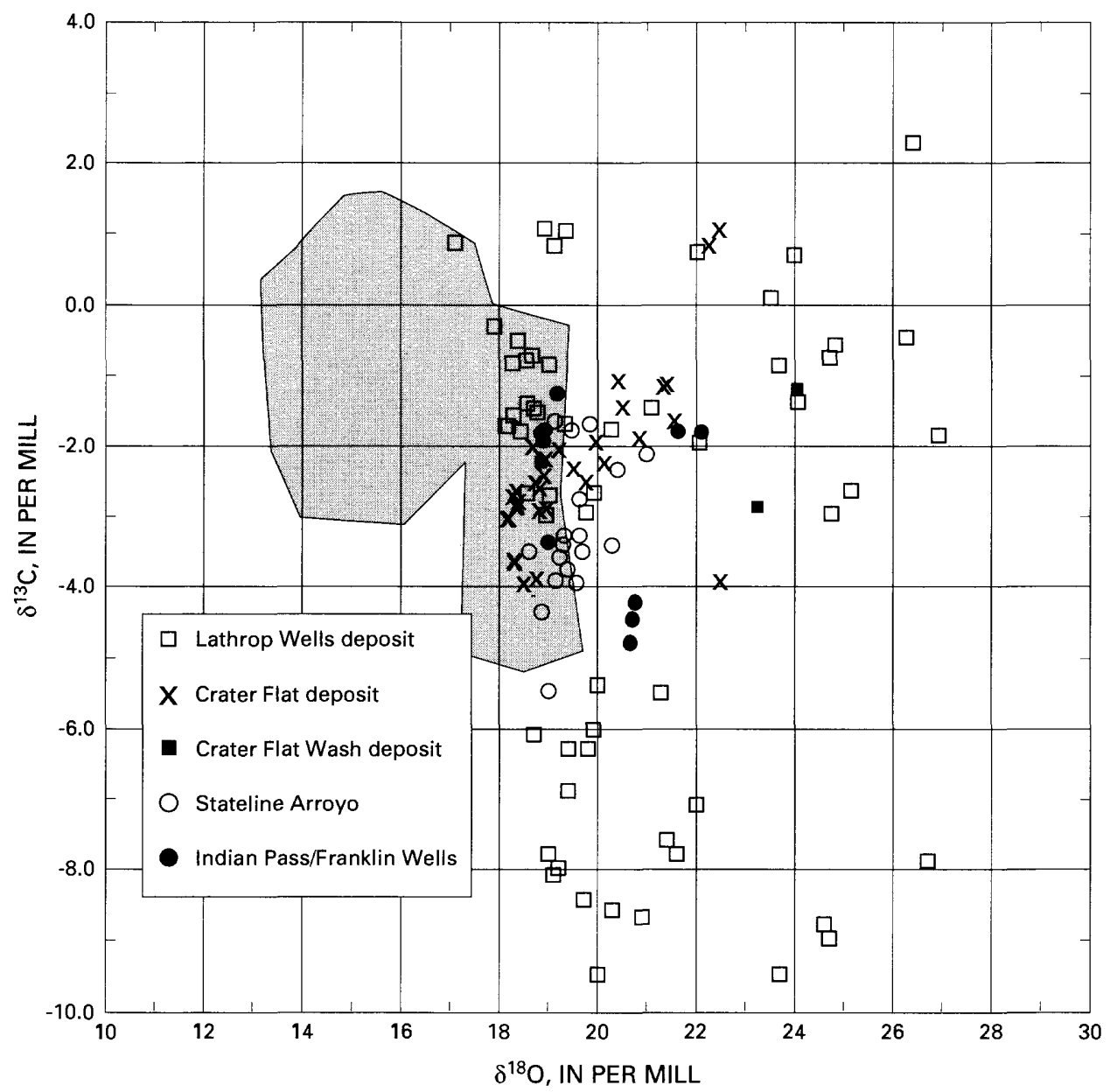

Figure 23. Stable carbon and oxygen isotopic compositions of carbonates from the paleodischarge deposits near Yucca Mountain, Nevada, plotted with different symbols representing each of the five sites. The shaded field represents compositions of tufa and travertine deposits associated with sites of active discharge from regional Paleozoic aquifers (Grapevine Springs and Nevares Spring in Death Valley, Devils Hole in Ash Meadows).

Thermoluminescence analysis dates the burial age of eolian silt deposited within the discharge deposits. Resulting total and partial bleach ages span a range between 13 and $120 \mathrm{ka}$, with the bulk of analyses in the 30 to $60 \mathrm{ka}$ range (fig. 23). These results are consistent with both stratigraphy and ${ }^{230} \mathrm{Th} / \mathrm{U}$ ages at most sites, except for the Lathrop Wells Diatomite deposits. In that case, more than $3.5 \mathrm{~m}$ of fine-grained deposits within the measured section yield a relatively uniform TL age of 40 to $30 \mathrm{ka}$. This narrow apparent time span comes from sediments above and below a major lithologic break yielding ${ }^{230} \mathrm{Th} / \mathrm{U}$ ages from the last and penultimate glacial cycles. The reason for this age discrepancy is unclear. In contrast, the lowermost fine-sand unit dated by TL at the State Line highterrace deposits yields a TL age of about $120 \mathrm{ka}$, consistent with the age of 105 to $97 \mathrm{ka}$ for the immediately overlying silica-cemented horizon.

Current geochronological investigations provide a reconnaissance-level framework of discharge activity at sites in southern Crater Flat and in the Amargosa Valley. The overall concordance between results from three independent chronometers supports the following interpretations:

-Discharge occurred during the latest glacial cycle between 20 to $10 \mathrm{ka}$. The consistency of the young ages obtained using the three independent methods strongly indicates a primary age signature rather than partial resetting of older deposits by younger processes (that is, climate-induced pedogenic overprinting). 
-Discharge activity between 20 and $10 \mathrm{ka}$ at all five sites is consistent with a regional phenomenon rather than isolated activity related to local hydrologic condition (see discussions under the Owens Lake, Lakes, Playas, and Marshes, and Terrestrial Records sections of this report).

- The ${ }^{230} \mathrm{Th} / \mathrm{U}$ data show discharge activity was cyclic and associated with the last and penultimate glacial cycles. Deposits from the penultimate glacial cycle are exposed only in the more deeply dissected sites at the Lathrop Wells Diatomite deposits and State Line deposits, with the possibility of older materials at the base of a shallow $(1.5 \mathrm{~m})$ pit at the Crater Flat deposits. Elsewhere, the older deposits are not exposed, have been removed by erosion, or have not yet been identified.

-Materials younger than about 16 to $10 \mathrm{ky}$ old have not been identified from any of the sites, including surface-lag deposits that form as these badland-type deposits are deflated. The absence of Holocene material indicates that the last discharge activity ceased around 15 to $12 \mathrm{ka}$ at upgradient sites and slightly later (about $9 \mathrm{ka}$ ) downgradient at lower elevations (as at the State Line deposits). This time corresponds to the cessation of the last cycle of spring activity in the Las Vegas and Pahrump Valleys (Quade and others, 1995) and reflects initiation of the hotter and dryer conditions typical of much of the Holocene interglacial interval.

\section{Paleontological Data and Paleoenvironmental Conditions}

Paleontological analyses of ostracodes, molluscs, and diatoms from samples collected from the Lathrop Wells Diatomite deposits, the Crater Flat deposits, and the Amargosa River site at the State Line deposits show that discharge was common in the past and supported a variety of discharge-related paleoenvironments. These paleoenvironments may be generally classified as seeps, flowing springs, and springsupported standing water (shallow pools and wetlands).

Paleoecological evidence indicates that seeps were common. These environments are characterized by low levels of ground-water discharge, minor surface-water flow, high seasonal variability of water temperature, and probable variation in water chem- istry. Flowing springs also were common and indicate that continuous ground-water discharge was sufficient to form streamlets. Streamlet temperatures and chemistries had low to moderate seasonal variability that likely was inversely proportional to discharge flux. Spring-supported pools and wetlands also were common in the region, particularly near the modernday Amargosa River. These open-water environments must have varied from a few meters in diameter to shallow ponds or lakes hundreds of meters in diameter. These environments were variously permanent or ephemeral. Dense stands of emergent aquatic vegetation (cattails, bulrush), grasses, or other vegetation occurred at these sites.

Paleoenvironmental reconstruction at the Lathrop Wells Diatomite paleodischarge site based on analyses of diatoms indicates the presence of a freely flowing alkaline spring system, probably with multiple spring orifices discharging throughout the history of activity. The spring water was silica-rich, only slightly saline, and possibly warm. Its chemistry probably resembled water from the volcanic aquifer. Spring flow was typically moderate to strong and probably passed through a mass of rush-like vegetation that grew at the site.

\section{Stable Isotope Data}

Stable carbon and oxygen isotopes in carbonates from paleodischarge sites provide information on the source of the discharging water $\left(\delta^{13} \mathrm{C}\right)$ and the temperatures at which recharge and discharge took place $\left(\delta^{18} \mathrm{O}\right)$. Paleodischarge deposits near Yucca Mountain are often carbonate-poor, unlike other springs in southern Nevada where discharge comes from deep, carbonate-hosted aquifers. Carbonate-poor deposits could be due to discharge waters with little capacity to precipitate calcite. This could be due to (1) dilute, calcite-undersaturated discharge waters; or (2) calcitesaturated, but calcium- or carbonate-poor waters.

Stable isotope data from the five paleodischarge sites show a large range in both $\delta^{18} \mathrm{O}$ values (18 to 27 per mil) and $\delta^{13} \mathrm{C}$ values ( -10 to +1 per mil) (fig. 23). These $\delta^{13} \mathrm{C}$ and $\delta^{18} \mathrm{O}$ values also show positive covariance, indicating evaporation and $\mathrm{CO}_{2}$ escape from discharge waters at the surface. The smallest inorganic carbonate $\delta^{18} \mathrm{O}$ values, representing materials least affected by surface processes, cluster around $19 \pm 1$ per mil. The range of $\delta^{13} \mathrm{C}$ remains large even for carbonates with minimum $\delta^{18} \mathrm{O}$ values, a feature that reflects mixing between the primary 
carbon inputs to these environments. Inorganically precipitated carbonate cements and nodules reflect the dissolved inorganic carbon in discharging waters and have $\delta^{13} \mathrm{C}$ values from -4 to +1 per mil. In contrast, mollusc shells and plant petrifactions have $\delta^{13} \mathrm{C}$ values of -10 to -5 per mil.

Carbonate tufas and travertines from Ash Meadows and Death Valley have $\delta^{13} \mathrm{C}$ values $(-5$ to +2 per mil) comparable to inorganically precipitated carbon at paleodischarge sites but typically have smaller $\delta^{18} \mathrm{O}$ values (+13 to +19 per mil) (fig. 23 ). Discharge temperatures of 25 to $35^{\circ} \mathrm{C}$ for these modern springs are commonly greater than mean annual temperatures, indicating that waters have thermally equilibrated along deep, warmer flow paths. The $\delta^{18} \mathrm{O}$ values in carbonates are related to temperature, with larger values coming from cooler waters. Further, evaporation increases the $\delta^{18} \mathrm{O}$ values of water and so also precipitates carbonates with higher $\delta^{18} \mathrm{O}$ values. The carbonates within the various discharge deposits that range to higher $\delta^{18} \mathrm{O}$ values may, therefore, reflect either evaporated and/or lower-temperature waters.

Minimum $\delta^{18} \mathrm{O}$ values of carbonate from each deposit most closely reflect the temperature and isotopic ratios of the discharging waters. At the carbonate-poor, fine-grained marsh and wetland paleodischarge deposits, these minimum $\delta^{18} \mathrm{O}$ values are roughly 3 per mil higher than those from the carbonate mounds at active sites such as Ash Meadows and Devils Hole. This difference reflects either cooler discharge temperatures or greater discharge $\delta^{18} \mathrm{O}$ values, or both, at the carbonate-poor sites. If nearequal discharge $\delta^{18} \mathrm{O}$ values are assumed for water for the two types of deposits, then discharge temperatures at the carbonate-poor sites were 0 to $16^{\circ} \mathrm{C}$, significantly cooler than the 25 to $35^{\circ} \mathrm{C}$ modern sites. If nearequal discharge temperatures are assumed, the 3 per mil lower discharge at the carbonate-poor sites probably reflects recharge at lower elevations than the carbonate-depositing sites. Although unlikely, if the carbonate-poor discharge deposits are associated with warm water discharge, the highest $\delta^{18} \mathrm{O}$ values also could result from those warm discharge waters cooling as they flowed away from the orifices. Regardless, either cooler temperatures or lower elevation recharge are more compatible with shallower and shorter ground-water flow paths for the carbonate-poor deposits, and this is likely the key difference between them and the carbonate mound deposits.

\section{Source of Water}

The source of discharging ground water is of critical importance for relating paleohydrologic responses to climate variations. Understanding whether the water at discharge sites came from a regional or a perched water table is central to modeling the SZ behavior under the anticipated future wetter climates. Synchronous paleodischarge at all five studied sites distributed over a broad area with heterogeneous hydrogeological conditions indicates the likelihood of a widespread rise in the regional SZ water table. Evidence from uranium, strontium, and carbon isotopic data supports that observation.

Initial ${ }^{234} U /{ }^{238} U$ activity ratios calculated for all materials analyzed from discharge deposits throughout the Amargosa Valley consistently vary between values of about 2.8 and 4.4 (fig. 22, table 3 ) over the last several hundred thousand years. Values from discharge deposits are clearly distinct from analyses of calcretes in the Yucca Mountain vicinity $\left({ }^{234} U /{ }^{238} U=1.3\right.$ to 1.8) (Paces and others, 1994, J.B. Paces, S.A. Mahan, K.R. Ludwig, L.K. Kwak, L.A. Neymark, K.R. Simmons, L.D. Nealey, B.D. Marshall, and A.W. Walker, U.S. Geological Survey, written commun., 1995). Similarly low values of ${ }^{234} U /{ }^{238} U$ are observed for surface-runoff waters collected during precipitation events at Yucca Mountain. Therefore, data from paleodischarge deposits clearly require a hydrologic source not dominated by surface waters or pedogenic processes

Like $\mathrm{U}$ data, $\mathrm{Sr}$ isotopes provide additional evidence that a surface-water origin is not feasible. Strontium isotopic compositions of weak-acid leaches largely from the vicinity of the southern Crater Flat and State Line deposits (J.B. Paces, written commun., 1995) yield a bimodal distribution of values based on location. Carbonates from the Lathrop Wells Diatomite deposits and Crater Flat deposits have $\delta^{87} \mathrm{Sr}$ values of 5.03 to 5.20 , whereas samples from the State Line deposits contain $\delta^{87} \mathrm{Sr}$ values between 10.5 and 13.1. Both groups are distinct from local calcretes that have a range of $\delta^{87} \mathrm{Sr}$ from 3.3 to 5.0 (Marshall and others, 1993; Marshall and Mahan, 1994).

Carbon from the inorganically precipitated carbonate at all sites contains a substantial component of heavy carbon ( -4 and +2 per mil) that is not observed in surface environments where plants control most of the carbon budget. Calcrete throughout the region has $\delta^{13} \mathrm{C}$ values of -10 to -5 per mil. Waters 
Table 3. Characteristic isotopic compositions of paleodischarge deposits, waters, and rocks representing possible source materials in the Yucca Mountain, Nevada, region.

\begin{tabular}{|c|c|c|c|}
\hline Material & $\begin{array}{c}\text { Initial }{ }^{234} \mathrm{U}^{238} \mathrm{U} \\
\text { Activity }\end{array}$ & $\delta^{87}$ Sr per mil & $\delta^{13} \mathrm{C}$ per mil \\
\hline \multicolumn{4}{|c|}{ Paleodischarge deposits } \\
\hline Inorganic carbonate & 2.9 to 4.5 & 5.0 to 13 & -4 to +1 \\
\hline Plant/mollusc & 2.9 to 4.5 & 5.0 to 13 & -10 to -5 \\
\hline \multicolumn{4}{|c|}{ Aquifers } \\
\hline Paleozoic & 2.5 to 4 & 3 to $>10$ & -4 to $-2\left(\mathrm{HCO}_{3}^{-}\right)^{*}$ \\
\hline Volcanic/alluvium & 3 to 8 & $\begin{array}{l}-0.7 \text { to } 4 \text { (no Precambrian) } \\
7 \text { to }>15 \text { (w/Precambrian) }\end{array}$ & -13 to $-7\left(\mathrm{HCO}_{3}{ }^{-}\right)^{*}$ \\
\hline $\begin{array}{l}\text { Perched waters at Yucca } \\
\text { Mountain }\end{array}$ & 3 to 7 & 3.5 to 4.5 & -11 to $-9\left(\mathrm{HCO}_{3}{ }^{-}\right)^{*}$ \\
\hline $\begin{array}{l}\text { Surface waters at Yucca } \\
\text { Mountain }\end{array}$ & 1.4 to 1.8 & 1.8 to 3.8 & \\
\hline \multicolumn{4}{|c|}{ Rocks } \\
\hline Marine carbonate & $\sim 1.0$ & -2 to $+3 * *$ & -2 to +2 \\
\hline Calcrete & 1.3 to 1.8 & 3.3 to 5.0 & -10 to -5 \\
\hline Volcanics & $\sim 1.0$ & -1.3 to 15 & Negligible contribution \\
\hline Precambrian siliciclastics & $\sim 1.0$ & 10 to $>30$ & Negligible contribution \\
\hline
\end{tabular}

that obtain their carbon during infiltration through the soil zone will acquire relatively low $\delta^{13} \mathrm{C}$ values $\left(-12\right.$ to -7 per mil). These $\delta^{13} \mathrm{C}$ compositions are widely observed in surface and shallow volcanic aquifer waters beneath Yucca Mountain (Benson and McKinley, 1985) and in UZ carbonates (Whelan and others, 1994, 1996). In contrast, calcite associated with Paleozoic aquifers has $\delta^{13} \mathrm{C}$ that reflects marine carbon sources (Coplen and others, 1994; Whelan and others, 1994).

Isotopic attributes of possible source waters as deduced from those of the carbonate spring deposits are permissible with deposition from SZ ground water. Data for ground water sampled from springs and wells throughout the Yucca Mountain region have a wide range of isotopic compositions (table 3 ), reflecting the isotope geochemistry of the recharge areas and of the aquifers along the flow paths. Uranium isotopic compositions $\left({ }^{234} \mathrm{U} /{ }^{238} \mathrm{U}\right)$ are highly variable in $\mathrm{SZ}$ and perched ground-water systems at Yucca Mountain. Published ${ }^{234} \mathrm{U} /{ }^{238} \mathrm{U}$ activity ratios range from 1.7 to 7.0 (Ludwig and others, 1993) and even larger values have been found in more recent studies. Generally, water samples from the regional carbonate aquifer have ${ }^{234} \mathrm{U}^{238} \mathrm{U}$ activity ratios between 1.7 and 3.5 with some exceptions. Ground water in the volcanic aquifer has ${ }^{234} \mathrm{U}^{238} \mathrm{U}$ ratios that overlap with those of the carbonate aquifer, but typically extend to values as large as 8.0. Perched ground water at Yucca Mountain has ${ }^{234} \mathrm{U} /{ }^{238} \mathrm{U}$ activity ratios similar to ground water from the volcanic aquifer. Thus, the ${ }^{234} \mathrm{U}^{238} \mathrm{U}$ ratios of 2.9 to 4.5 for calcite spring deposits are mostly in the area of overlapping values for the regional carbonate aquifer and the volcanic aquifer.

Strontium isotopic compositions of ground water from springs and wells in the Yucca Mountain region have $\delta^{87} \mathrm{Sr}$ values that range from -0.7 to extremely large values as great as +39.0 (fig. 24 , table 3). However, the majority of $\delta^{87} \mathrm{Sr}$ values are in the range of 0 to +14 , and values for ground water in the volcanic aquifer at Yucca Mountain proper are even more restricted between +1 and +4 . Northward from Yucca Mountain, ground-water $\delta^{87} \mathrm{Sr}$ values decrease to 0 into the recharge areas and increase southward into the Amargosa Desert to values as large as +11 (Peterman and Stuckless, 1993a). Ground water contacting only Paleozoic carbonate rocks in the regional carbonate aquifer would be expected to have $8^{87} \mathrm{Sr}$ values in the range of -2 to +3 (table 3 ) except where the carbonates have been mineralized by 


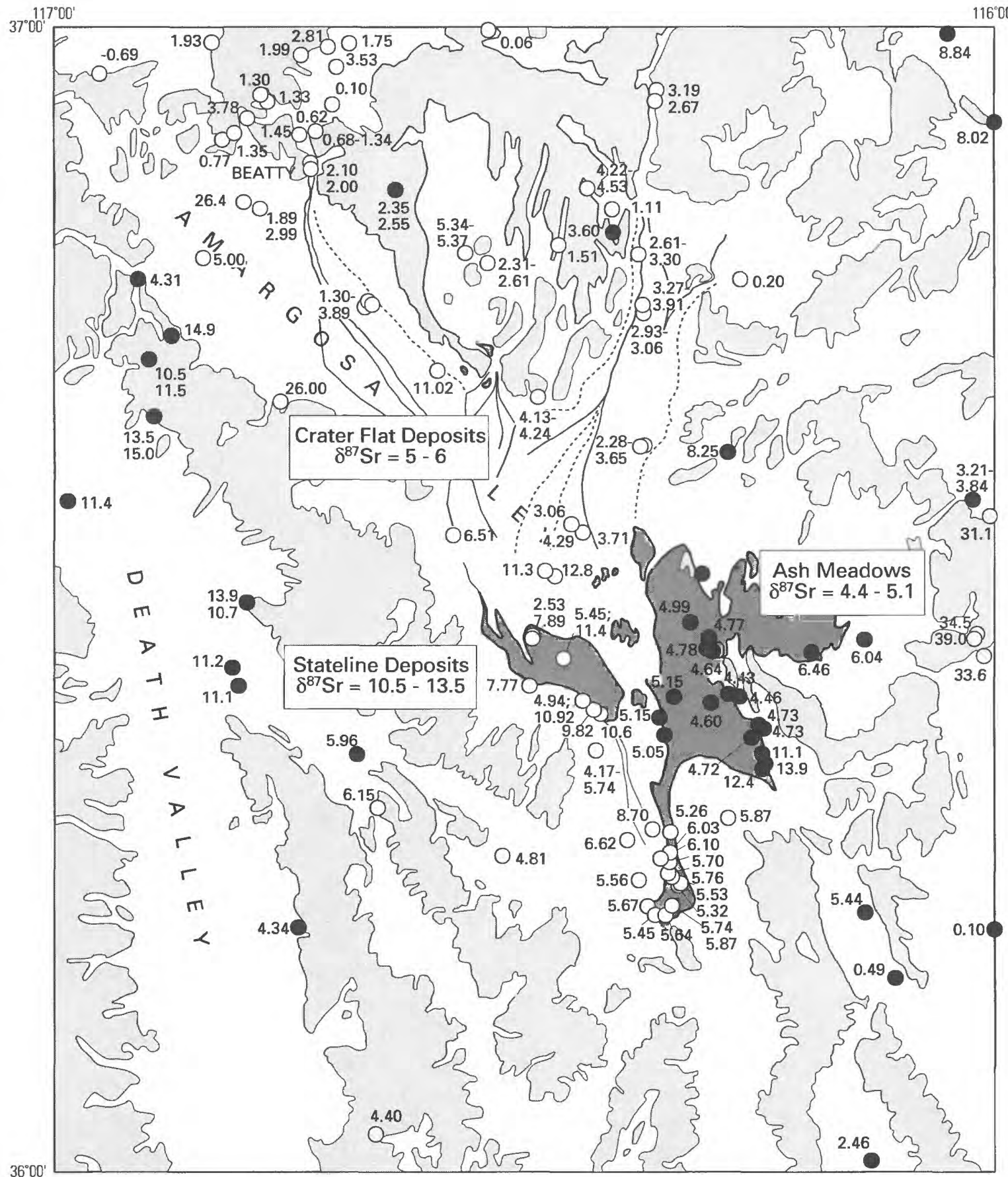

Figure 24. Location of wells and springs analyzed for delta strontium-87 (values in per mil relative to seawater with ${ }^{87} \mathrm{Sr} /{ }^{86} \mathrm{Sr}$ value of 0.70920 ) from waters. Bedrock ranges are shown in shaded patterns, and alluvium-filled valleys are shown unpatterned. Solid and dashed lines within alluvial valleys represent active channels and alluvial fan boundaries, respectively. Dark circles represent sample sites classified as Paleozoic aquifer; open circles represent sample sites from volcanic or alluvial aquifers. 
hydrothermal solutions, such as at Bare Mountain, where $\delta^{87} \mathrm{Sr}$ values are as large as +23 (Peterman and others, 1994). The only borehole penetrating the regional carbonate aquifer at Yucca Mountain is UE$25 \mathrm{p} \# 1$, and water from the aquifer has a $\delta^{87} \mathrm{Sr}$ value of +3.6 , which contrasts with values of 0 to +0.2 for core samples of the Paleozoic limestones from the hole.

Peterman and others (1994) indicated that the lack of equilibrium between the ground water and the aquifer at this location was likely the result of upgradient interaction with rocks having substantially larger $\delta^{87} \mathrm{Sr}$ values, such as the Devonian-Mississippian Eleana Argillite with a mean $\delta^{87} \mathrm{Sr}$ of +9.8 . Such interaction with rocks containing radiogenic $\mathrm{Sr}$ appears to be fairly common in the regional carbonate aquifer, which indicates that more flow occurs through the fractured Precambrian basement than has previously been thought (Peterman and Stuckless, 1993a, b). For example, springs in the high Spring Mountains representing ground-water recharge that has encountered only Paleozoic carbonate rocks have a mean $\delta^{87} \mathrm{Sr}$ value of $-1.1 \pm 0.6$ ( 1 sigma), whereas most of the spring discharge at Ash Meadows has a mean $\delta^{87} \mathrm{Sr}$ of $+4.7 \pm 0.2$ (Peterman and others, 1992b). This increase in $\delta^{87} \mathrm{Sr}$ along the flow path from recharge to discharge indicates interaction with Precambrian siliciclastic units which are the source of the radiogenic Sr. Three springs at the southern end of the spring line have larger $\delta^{87} \mathrm{Sr}$ values between +11 to +14 (fig. 24), reflecting even greater interaction with Precambrian rocks in the northwestern Spring Mountains.

Possible water sources for the paleodischarge deposits based on isotopic and fossil data are summarized in table 4. Neither perched nor surface-runoff waters will satisfy the isotopic attributes of the spring carbonate deposits. Calcite samples from the Lathrop Well diatomite and Crater Flat deposits have $\delta^{87} \mathrm{Sr}$ values between +5 and +6 (fig. 24). Ground-water sampled from well VH-2 in Crater Flat upgradient from these deposits has a dissolved ion composition similar to water from the regional carbonate aquifer, is slightly saturated in calcite, and has a $\delta^{87} \mathrm{Sr}$ value of +5.4 . Thus, the SZ ground water like that encountered in VH-2 could have been the source of the calcite spring in these deposits. In contrast, water from an adjacent well ( $\mathrm{VH}-1)$ has a dissolved ion composition and $\delta^{87} \mathrm{Sr}$ value $(+2.5)$, which are similar to $\mathrm{SZ}$ water from the volcanic aquifer at Yucca Mountain. Such isotopic and chemical heterogeneities are not unexpected in a ground-water system dominated by fracture flow where contrasting rock types have been structurally juxtaposed.

Similarly, ground water with appropriate isotopic compositions exists upgradient from the State Line deposits. Calcite samples from those deposits have $\delta^{87} \mathrm{Sr}$ values between +10.5 and +13.5 , and ground water from the deeper part of the upgradient aquifer has similar high values of +9.8 to +11.4 , presumably derived by flow through late Proterozoic rocks like those exposed in the nearby Funeral Range or through similar alluvium within the Amargosa basin. As in Crater Flat, aquifer heterogeneity and complexity is indicated by $\delta^{87} \mathrm{Sr}$ values between +3.1 and +5.5 for samples from shallower parts of the aquifer. The correspondence between $\delta^{87} \mathrm{Sr}$ values of the spring deposits and the upgradient ground waters strongly indicates that ground-water discharge occurred at this site and the sites near the southern end of Crater Flat.

\section{Water-Table Fiuctuations Under Yucca Mountain}

Combined isotopic evidence, including ${ }^{234} \mathrm{U} /{ }^{238} \mathrm{U},{ }^{87} \mathrm{Sr} /{ }^{86} \mathrm{Sr}$, and ${ }^{13} \mathrm{C} /{ }^{12} \mathrm{C}$ as well as spatial and temporal data, indicates that discharging water at paleospring sites represents regional ground waters rather than local perched systems. This conclusion

Table 4. Matrix of possible hydrogenic sources and their compatibility with observed data from paleodischarge sites near Yucca Mountain, Nevada

\begin{tabular}{lllll}
\hline $\begin{array}{c}\text { Hydrogenic } \\
\text { source }\end{array}$ & $\begin{array}{c}\text { Initial } \\
\text { activity }\end{array}$ & $\delta^{{ }^{837}} \mathrm{Sr}$ (per mil) & $\delta^{\mathbf{1 3}} \mathrm{C}$ (per mil) & Diatoms \\
\hline Paleozoic aquifer & Possible & Possible & Possible & Unlikely \\
Volcanic/alluvial aquifer & Possible & Possible & Possible & Probable \\
Perched aquifer & Possible & No & No & No \\
Surface runoff & No & No & No & No \\
\hline
\end{tabular}


requires that the regional water-table elevation fluctuated in the past as a response to the higher effective moisture available during wetter climates.

Currently, the water-table elevations beneath the sites closest to Yucca Mountain (Lathrop Wells Diatomite deposits, Crater Flat Wash deposits, and Crater Flat deposits) are extrapolated from potentiometricsurface maps (Waddell and others, 1984; Robison, 1984; Claassen, 1985) because no direct measurements are available. These estimates provide a current depth to water of between 80 and $120 \mathrm{~m}$ (Paces and others, 1993). Similar deposits are not found at higher elevation in this area, indicating that these deposits represent a maximum water-table rise over the last $250 \mathrm{ka}$.

The fluctuations in water-table elevation as recorded at paleodischarge sites may be localized by unidentified hydrogeologic features inasmuch as these deposits are not widespread nor uniformly distributed along areas of equal topographic elevation. However, they probably do not represent the result of an overpressured discharge of a confined aquifer because similar estimates of maximum water-table elevations under Yucca Mountain have been made on the basis of fracture-filling secondary minerals (Marshall and others, 1993) and distribution of zeolitization in tuffs (Levy, 1991). An overpressured system would not produce uniform water-table elevation changes over broad areas. A similar rise in the water-table elevation in the vicinity of the potential repository block at Yucca Mountain (maximum increase of $130 \mathrm{~m}$ ) also has been modeled using a 15-times increase in recharge responding to doubling MAP relative to modern day (Czarnecki, 1985).

\section{Response of the Water Table to Climatic Variation}

One of the main consequences of this work is recognition that higher regional water-table elevations up to $120 \mathrm{~m}$ above present-day levels were common during the last two glacial cycles (60 to $10 \mathrm{ka}$ and 170 to $100 \mathrm{ka}$ ). The paleodischarge deposits do not contain a continuous sedimentary record like those from lakes. However, the ages obtained thus far do agree with regional climate records (fig. 6); see also discussion above related to Owens Lake. Several important conclusions are apparent from these studies.
First, the close correspondence between climate records and discharge records implies a direct response of the water table to climate change. There is no apparent lag between the time when climate records identify the availability of surface water to the time when it is observable at discharge sites. This indicates rapid readjustment to increased levels of recharge and translation of the increased recharge downgradient to points of discharge.

Second, much of the late Pleistocene was characterized by higher water-table elevations. Higher water-table elevations may be a normal consequence of Pleistocene climate conditions, and the lower watertable elevations observed today may be typical only of the relatively short, anomalously dry interglacial periods.

Third, multiple climate-cycle histories are recorded at paleodischarge sites, as well as at Devils Hole and Owens Lake. Therefore, water-table elevations as well as regional and local hydrological phenomena have responded to climate change in the past and will continue to do so in the future, which is consistent with studies by Winograd and Doty (1980), Winograd and others (1985), and Winograd and Szabo (1988).

\section{CONCLUSIONS}

1. The general features of the climate system, at a millenial scale, can be identified from the timing of insolation change, which is calculated for the past and future. Insolation change occurs in a 400-ky cycle subdivided into four subcycles. A glacial and interglacial couplet are embedded within each subcycle. The insolation characteristics for each glacial/interglacial couplet are not identical, and the corresponding climate characteristics also differ rom one cycle to the next. The timing of insolation change indicates the next glacial cycle will begin within the next few centuries to millennia and the insolation characteristics are most similar to those from the period $400 \mathrm{ka}$ to $350 \mathrm{ka}$ during the glacial period called OIS-10. 
2. The well-dated isotopic record of climate change from Devils Hole provides a complete record of the timing of all the glacial/interglacial couplets that have occurred during the past $500 \mathrm{ky}$. The appearance of glacial periods is essentially the same in both records, but some glacial termination evens occur earlier in the Devils Hole record. The discrepancy in timing between some termination events on the Devils Hole record and in SPECMAP (an integrated marine record of global climate change) may reflect the importance of numerous short-term, earth-based forcing functions on the climate system. Whatever the cause of termination events, the Devils Hole record shows insolation change is not the lone driver or perhaps a driver of those phenomena.

3. The Owens Lake climate record, interpreted from two climate proxy data sets (diatoms and ostracodes), shows a regional expression of all glacial/interglacial couplets from the past $500 \mathrm{ky}$ and indicates the wetter and cooler glacial modes are resident about 80 percent of the time. Further, the characteristics of each glacial/interglacial cycle differ from each other, as does the insolation characteristics of each cycle. The past glacial/interglacial couplet most similar to the insolation characteristics for the next $100 \mathrm{ky}$, from preliminary interpretation of the Owens Lake record was not as cold as the last two couplets but may have been as wet or wetter.

4. The local aquatic and terrestrial records of climate change during the last glacial cycle (40 to $10 \mathrm{ka}$ ) reveal that glacial cycles are climatically complex periods composed of numerous centuryand millennial-scale episodes having different climate characteristics. During the last glacial interval, MAP was on average about twice modern, but episodes when MAP was higher are also believed to have existed. Mean annual temperature was typically quite low, commonly around $4^{\circ}$ to $5^{\circ} \mathrm{C}$, or colder. Effective moisture was nearly always higher than modern during the glacial period due to past combinations of MAP and MAT.

5. Fortymile Wash responded to climate change by variously aggrading or incising portions of the now largely dry wash. During glacial times, the wash appears to have supported a gaining stream in its upper reaches that incised alluvial material near Yucca Mountain. Incision in part may be related to vegetation-stabilized slopes. Conversely, in transition periods from or into a glacial period, the stream aggraded. During dry interglacial periods, the stream remained relatively static with little aggradation or incision.

6. Stable and radiogenic isotope data from calcite and opal formed in fractures within the UZ of Yucca Mountain reveal that those minerals were derived from infiltrating waters. Infiltration appears to have occurred during glacial times, when $\mathrm{C} 3$ plants lived in the region indicating colder MAT than today. Calcite $\delta^{18} \mathrm{O}$ data indicate the infiltration had isotopic characteristics associated with arctic to maritime polar air if MAT values around $5^{\circ} \mathrm{C}$ are assumed. A warmer MAT would indicate less input from arctic and more from polar/tropical sources. These data identify the climate characteristics of those percolating waters responsible for calcite formation. Strontium isotopes show a consistent pattern of the percolation solute load derived from the surface, where the strontium, in part, was derived from dissolution of calcretes.

7. Ages of secondary minerals derived from uraniumseries and radiocarbon analyses indicate formation primarily, but not exclusively, during glacial periods. Mineral formation primarily during the glacial periods may imply the repository block behaves as a relatively open hydrological system that responds rapidly to climate change.

8. Strontium isoptope data from the present $\mathrm{UZ}$ within Yucca Mountain reveal that the regional water table may have been about $100 \mathrm{~m}$ higher at some unknown time in the past. Isotopic studies and dating of past discharge deposits down-gradient from Yucca Mountain reveal that during the last and penultimate glacial periods the regional water table rose as much as $100 \mathrm{~m}$, creating wetlands, flowing springs, and seeps from Crater Flat to the Amargosa River. Strontium isotope data from well water link modern Crater Flat ground-water and the nearby ground-water discharge deposits.

9. A positive correlation appears to exist between changes in the 400-ky insolation cycle, climate change, and the hydrologic behavior of the UZ and the SZ within Yucca Mountain. 


\section{REFERENCES}

Ahrens, C.D., 1985, Meteorology today, an introduction to weather, climate, and the environment ( $2 \mathrm{~d}$ ed.):

St. Paul, Minn., West Publishing, 524 p.

Beatley, J.C., 1976, Vascular plants of the Nevada Test Site and central-southern Nevada-Ecologic and geographic distributions: Virginia, National Technical Information Service, $308 \mathrm{p}$.

Bedinger, M.S, Harril, J.R., and Thomas, J.M., 1984, Maps showing ground-water units and withdrawal, Basin and Range Province, Nevada: U.S. Geological Survey Water-Resources Investigations Report 83-4119-A, 10 p., scale 1:500,000, 2 plates.

Bedinger, M.S., Langer, W.H., and Moyle, W.R., 1984, Maps showing ground-water units and withdrawal, Basin and Range Province, southern California: U.S. Geological Survey Water-Resources Investigations Report 83-4116-A.

Benson, L.V., and McKinley, P.W., 1985, Chemical composition of ground water in the Yucca Mountain area, 1971-84: U.S. Geological Survey Open-File Report 85-484, $10 \mathrm{p}$.

Benson, L.V., and Kleiforth, H., 1989, Stable isotopes in precipitation and ground water in the Yucca Mountain region, southern Nevada—Paleoclimatic implications, in Peterson, D.H., ed., Aspects of climate variability in the Pacific and the western Americas: American Geophysical Union Monograph 55, p. 41-59.

Berger, A., and Loutre, M.F., 1991, Insolation values for the climate of the last 10 million years: Quaternary Sciences Review, v. 10, p. 297-317.

Bischoff, J.L., 1993, Age-depth relations for the sediment column at Owens Lake, California-OL-92 drill hole, in Smith, G.I., and Bischoff, J.L., eds., Core OL-92 from Owens Lake, southeast California: U.S. Geological Survey Open-File Report 93-683, p. 251-260.

Bish, D.L., and Aronson, J.L., 1993, Paleogeothermal and paleohydrologic conditions in silicic tuff from Yucca Mountain, Nevada: Clays and Clay Minerals, v. 41, no. 2, p. 148-161.

Bradbury, J.P., 1993, Diatoms in sediments, in Smith, G.I., and Bischoff, J.L., eds., Core OL-92 from Owens Lake, southeast California: U.S. Geological Survey Open-File Report 93-683, p. 261-301.

Bradbury, J.P., Forester, R.M., and Thompson, R.S., 1989, Late Quaternary paleolimnology of Walker Lake, Nevada: Journal of Paleolimnology, v. 1, p. 249-267.
Brennan, R., and Quade, J., 1995, Radiocarbon dating of fossil mollusk shells in the Yucca Mountain region, in High-Level Radioactive Waste Management, Proceedings of the Sixth International Conference, Las Vegas, Nevada, 1995, LaGrange Park, Illinois, American Nuclear Society, p. 182-183.

Broxton, D.C., Bish, D.L., and Warren, R.G., 1987, Distribution and chemistry of diagenetic minerals at Yucca Mountain, Nye County, Nevada: Clays and Clay Minerals, v. 35, no. 2, p. 89-110.

Chapman, N.A., and McEwen, T.J., 1993, The application of palaeohydrogeological information to repository performance assessment, in Paleohydrogeological methods and their applications: Proceedings of an NEA Workshop, November 1992, p. 23-35.

Charlet, D.A., 1995, Great Basin montane and subalpine conifer diversity-Dispersal or extinction pattern?: Reno, University of Nevada, unpublished Ph.D. dissertation, $179 \mathrm{p}$.

Claassen, H.C., 1985, Sources and mechanisms of recharge for ground water in the west-central Amargosa Desert, Nevada-A geochemical interpretation: U.S. Geological Survey Professional Paper 712-F, 31 p.

Coe, J., Glancy, P., and Whitney, J.W., 1995, Volumetric analysis and hydrologic characterization of a modern debris flow near Yucca Mountain, Nevada: U.S. Geological Survey Administrative Report, 50 p.

Coplen, T.B., Winograd, I.J., Landwehr, J.M., and Riggs, A.C., 1994, 500,000-year stable carbon isotopic record from Devils Hole, Nevada: Science, v. 263, p. 361-365.

Cronquist, A., Holmgren, A.H., Holmgren, N.H., and Reveal, J.L., 1972, Intermountain flora-Vascular plants of the intermountain west, U.S.A., volume 1: New York, Hafner Publishing Company, Inc., 270 p.

Czarnecki, J., 1985, Simulated effects of increased recharge on the ground-water flow system of Yucca Mountain and vicinity, Nevada-California: U.S. Geological Survey Water-Resources Investigation Report 84-4344, 33 p.

Delorme, L.D., 1970, Freshwater ostracodes of Canada, Part IV, Families Ilyocyprididae, Notodromadidae, Darwinulidae, Cytherideidae, and Entocytheridae: Canadian Journal of Zoology, v. 48, no. 6, 1251-1259.

Enzel, Y., Cayan, D.R., Anderson, R.Y., and Wells, S.G., 1989, Atmospheric circulation during Holocene lake stands in the Mojave Desert-Evidence of regional climate change: Nature v. 341, p. 44-47.

Eugster, H.P., and Jones, B.F., 1979, Behavior of major solutes during closed-basin brine evolution: American Journal of Science, v. 279, p. 609-631. 
Flora of North America Editorial Committee, 1993, Flora of North America: North of Mexico. Volume 2: Pteridophytes and Gymnosperms: Oxford University Press, New York.

Forester, R.M., 1983, Relationship of two lacustrine ostracode species to solute composition and salinityImplications for paleohydrochemistry: Geology, v. 11, p. 435-438.

Forester, R.M., 1986, Determination of the dissolved anion composition of ancient lakes from fossil ostracodes: Geology, v. 14, p. 796-798.

Forester, R.M., Colman, S.M., Reynolds, R.L., Keigwin, L.D., 1994, Lake Michigan's late Quaternary limnological and climate history from ostracode, oxygen isotope, and magnetic susceptibility records: Journal of Great Lakes Research, v. 20, p. 93-107.

Forester, R.M., and Smith, A.J., 1994, Late glacial climate estimates for southern Nevada, the ostracode record, in High Level Radioactive Waste Management, Proceedings of the Fifth International Conference, Las Vegas, Nevada, (DATE), LaGrange Park, Illinois, American Nuclear Society, p. 2553-2561.

Fritz, S.C., Juggins, S., and Battarbee, R.W., 1993, Diatom assemblages and ionic characterization of lakes of the Northern Great Plains, North America-A tool for reconstructing past salinity and climate fluctuations: Canadian Journal of Fishery Aquatic Sciences, v. 50, p. 1844-1856.

Gale, H.S., 1914, Salines in the Owens, Searles, and Panamint Basins, southeastern California: U.S. Geological Survey Bulletin 580-L, p. 251-323.

Glen, J.M., Coe, R.S., Menking, K., Boughn, S.S., and Altschul, I., 1993, Rock and paleomagnetic results from core OL-92, Owens Lake, California, in Smith, G.I., and Bischoff, J.L., eds., Core OL-92 from Owens Lake, southeast California: U.S. Geological Survey Open-File Report 93-683, p. 127-183.

Graybill, A.D., Rose, M.R., and Nials, F.L., 1994, Treerings and climate-Implications for Great Basin paleoenvironmental studies, in High-Level Radioactive Waste Management, Proceedings of the Fifth International Conference, Las Vegas, Nevada, 1994: LaGrange Park, Illinois, American Nuclear Society, p. 2569-2573.

Grootes, P.M., 1993, Interpreting continental oxygen isotope records, in Swart, P.M., Lohmann, P.K., McKenzie, K.C., and Savin, S., eds., Climate change in Continental Isotopic Records: Geophysical Monograph 78, p. 37-46.

Hall, E.R., 1995, Mammals of Nevada (updated edition of the 1946 original): Reno, University of Nevada Press, $710 \mathrm{p}$.
Hansen, E.M., Schwarz, F.K., and Riedel, J.P., 1981, Meteorology of important rainstorms in the Colorado River and Great Basin drainages: Silver Spring, Md., National Oceanic and Atmospheric Administration, Hydrometeorological Report 50, 167 p.

Hollett, K.J., Danskin, W.R., McCaffrey, W.F., and Walti, C.L., 1991, Geology and water resources of Owens Valley, California: U.S. Geological Survey WaterSupply Paper 2370, Chapter B, 77 p.

Houghton, J.G., 1969, Characteristics of rainfall in the Great Basin.: Reno, University of Nevada, Desert Research Institute.

Houghton, J.G., Sakamoto, C.M., and Gifford, R.O., 1975, Nevada's weather and climate: Reno, Nevada Bureau of Mines and Geology, Special Publication 2.

Hunt, C.B., 1973, Natural regions of the United States and Canada: San Francisco, W. H. Freeman.

Imbrie, J., Hays, J.D., Martinson, D.G., McIntyre, A., Mix, A.C., Morley, J.J., Pisias, N.G., Prell, W.L., and Shackleton, N.J., 1984, The orbital theory of Pleistocene climate-Support from a revised chronology of the marine $\delta^{18} \mathrm{O}$ record, in Berger, A.L., Imbrie, J., Hays, J., Kukla, G., and Saltzman, B., eds., Milankovich and climate, Boston, D. Reidel, p. 269-305.

Kay, P.A., 1982, A perspective on Great Basin paleoclimates, in Madsen, D.B., and O'Connell, J.F., eds., Man and the environment in the Great Basin: Society of American Archaeology Papers 2, p. 76-81.

Laacke, R.J., 1990, Abies concolor (Gord. \& Glend.) Lindl.ex Hildebr. White Fir., in Burns, R. M. and B. H. Honkala (Technical Coordinators), Silvics of North America: Volume 1, Conifers: Agriculture Handbook 654, Forest Service, United States Department of Agriculture, p. 36-46.

Levy, S.S., 1991, Mineralogic alteration history and paleohydrology at Yucca Mountain, Nevada, in High-Level Radioactive Waste Management, Proceedings of the Second International Conference, Las Vegas, Nevada, 1993, LaGrange Park, Society, p. 477.

Ludwig, K.R., Simmons, K.R., Szabo, B.J., Winograd, I.J., Landwehr, J.M., Riggs, A.C., and Hoffman, R.J., 1992, Mass spectrometric ${ }^{230} \mathrm{U}_{-}{ }^{234} \mathrm{U}-{ }^{238} \mathrm{U}$ dating of the Devils Hole calcite vein: Science, v. 258, p. 284-287.

Ludwig, K.R., Peterman, Z.E., Simmons, K.R., and Gutentag, E.D., 1993, ${ }^{234} \mathrm{U} /{ }^{238} \mathrm{U}$ ratios as a groundwater flow tracer, southwest Nevada-southeast California, in High-Level Radioactive Waste Management, Proceedings of the Fourth International Conference, Las Vegas, Nevada, 1993: LaGrange Park, Illinois, American Nuclear Society, p. 1567-1572.

Lundstrom, S.C., and Taylor, E.M., in press, Preliminary surficial deposits map of the southern half of the Topopah Spring northwest quadrangle: U.S. Geological Survey Open-File Report 95-132, scale 1:12,000. 
Lundstrom, S.C., and Warren, R.G., 1994, Late Cenozoic evolution of Fortymile Wash-Major change in drainage pattern in the Yucca Mountain, Nevada, region during late Miocene volcanism in High Level Radioactive Waste Management, Proceedings of the Fifth Annual International Conference, Las Vegas, Nevada, (DATE), LaGrange Park, Illinois, American Nuclear Society, v. 4, p. 2121-2130.

Lundstrom, S.C., Mahan, S.A., and Paces, J.B., in press, Preliminary surficial deposits map of the northwest quarter of the Busted Butte 7.5' quadrangle, Nye County, Nevada: U.S. Geological Survey Open-File Report 95-133.

Lundstrom, S.C., Westling, J.R., and Taylor, E.M., in press, Preliminary surficial deposits map of the northeast quarter of the Busted Butte 7.5' quadrangle, Nye County, Nevada: U.S. Geological Survey Open-File Report 94-341.

Lundstrom, S.C., Whitney, J.W., Paces, J.B., Mahan, S.A., and Ludwig, K.R., in press, Preliminary map of the surficial deposits of the southern half of the Busted Butte $7.5^{\prime}$ quadrangle, Nye County, Nevada: U.S. Geological Survey Open-File Report 95-311.

Machette, M.N., 1985, Calcic soils of the southwestern United States: Geological Society of America Special Paper, 203, p. 1-21.

Marshall, B.D., Peterman, Z.E., and Stuckless, J.S., 1993, Strontium isotopic evidence for a higher water table at Yucca Mountain. in High Level Radioactive Waste Management, Proceedings of the Fourth International Conference, Las Vegas, Nevada, (DATE): LaGrange Park, Illinois, American Nuclear Society, v. 2, p. 1948-1952.

Marshall, B.D., Peterman, Z.E., and Stuckless, J.S., 1994, Paleohydrology from strontium isotopes at Yucca Mountain, Nevada, in Lanphere, M.A., Dalrymple, G.B., and Turrin, B.D., eds., Abstracts of the Eighth International Conference on Geochronology, Cosmochronology, and Isotope Geology: U.S. Geological Survey Circular 1107, p. 203.

Marshall, B.D., Whelan, J.F., Peterman, Z.E., Futa, K., Mahan, S.A., and Stuckless, J.S., 1992, Isotopic studies of fracture coatings at Yucca Mountain, Nevada: Proceedings of the Seventh International Symposium on Water-Rock Interaction, Rotterdam, A.A. Balkema, v. 1, p. 737-740.

Marshall, B.D., and Mahan, S.A., 1994, Strontium-isotope geochemistry of soil and playa deposits near Yucca Mountain, Nevada, in High-Level Radioactive Waste Management, Proceedings of the Fifth International Conference, Las Vegas, Nevada, 1994: LaGrange, Illinois, American Nuclear Society, p. 2685-2691.
Marshall, B.D., Peterman, Z.E., Futa, K., Stuckless, J.S., Mahan, S.A., Downey, J.S., and Gutentag, E.D., 1990, Origin of carbonate deposits in the vicinity of Yucca Mountain, Nevada, Preliminary results of strontiumisotope analysis in High Level Radioactive Waste Management, Proceedings of the First International Conference, Las Vegas, Nevada, (DATE): LaGrange Park, Illinois, American Nuclear Society, v. 2, p. 921-923.

Mead, J.I., Thompson, R.S., and Long, A., 1978, Arizona radiocarbon dates IX - Carbon-isotope dating of packrat middens: Radiocarbon, v. 20, p. 171-191.

Mehringer, P.J., and Ferguson, C.W., 1969, Pluvial occurrence of Bristlecone Pine (Pinus aristata) in a Mojave Desert mountain range: Journal of the Arizona Academy of Science 5(4), p. 284-292.

Mehringer, P.J., and Warren, C.N., 1976, Marsh, dune and archaeological chronology, Ash Meadows, Amargosa Desert, Nevada, in Elston, R.G., and Headrick, P., eds., Holocene environmental change in the Great Basin, Nevada: Reno, Archeological Survey Research Papers 6, p. 120-150.

Mehringer, P.J., Jr., 1967, Pollen analysis of the Tule Springs area, Nevada, in Wormington, H.M., and Ellis, D., eds., Pleistocene studies in southern Nevada: Nevada State Museum, Anthropological Papers 13, p. 131-200.

Menking, K.M., Musler, H.M., Fitts, J.P., Bischoff, J.L., and Anderson, R.S., 1993, Clay mineralogical analyses of the Owens Lake core, in Smith, G.I., and Bischoff, J.L., eds., Core OL-92 from Owens Lake, southeast California: U.S. Geological Survey Open-File Report 93-683, p. 75-82.

O’Neil, J.R., Clayton, R.N., and Mayeda T.K., 1969, Oxygen isotope fractionation in divalent metal carbonates: Journal of Chemistry and Physics, v. 51, p. 5547-5558.

Paces, J.B., 1996, Dating of fracture coatings in the ESF: U.S. Geological Survey 1996 Milestone Report DGQH455, $20 \mathrm{p}$.

Paces, J.B., Menges, C.M., Widmann, B., Wesling, J.R., Bush, C.A., Futa, K., Millard, H.T., Maat, P.B., and Whitney, J.W., 1994, Preliminary U-series disequilibrium and thermoluminescence ages of surficial deposits and paleosols associated with Quaternary faults, eastern Yucca Mountain, in High-Level Radioactive Waste Management, Proceedings of the Fifth International Conference, Las Vegas, Nevada, 1994: LaGrange Park, Illinois, American Nuclear Society p. 2391-2401. 
Paces, J.B., Taylor, E.M., and Bush, C.A., 1993, Late Quaternary history and uranium isotopic compositions of ground water discharge deposits, Crater Flat, Nevada, in High-Level Radioactive Waste Management, Proceedings of the Fourth International Conference, Las Vegas, Nevada, 1993: LaGrange Park, Illinois, American Nuclear Society, v. 2, p. 1573-1580.

Peterman, Z.E., Stuckless, J.S., Marshall, B.D., Mahan, S.A., and Futa, K.A., 1992a, Strontium isotope geochemistry of calcite fracture fillings in deep core, Yucca Mountain, Nevada-A progress report in High Level Radioactive Waste Management, Proceedings of the Third International Conference, Las Vegas, Nevada, (DATE): LaGrange, Illinois, American Nuclear Society, p. 1582-1586.

Peterman, Z.E., Stuckless, J.S., Mahan, S.A., Marshall, B.D., Gutentag, E.D., and Downey, J.S., 1992b, Strontium isotope characterization of the Ash Meadows ground-water system, southern Nevada, USA, in Kharaka, Y.K., and Maest, A.S., eds., Waterrock interaction-Proceedings of the seventh International Symposium on Water-Rock Interaction: Rotterdam, A.A. Balkema, v. 1, p. 825-829.

Peterman, Z.E., Widmann, B.L., Marshall, B.D., Aleinikoff, J.N., Futa, K., Mahan, S.A., 1994, Isotopic tracers of gold deposition in Paleozoic limestones, southern Nevada in High Level Radioactive Waste Management, Proceedings of the Fifth International Conference, Las Vegas, Nevada, (DATE): LaGrange, Illinois, American Nuclear Society, v. 4, p. 1316-1323.

Peterman, Z.E., and Stuckless, J.S., 1993a, Isotopic evidence of complex ground-water flow at Yucca Mountain, Nevada, USA in High Level Radioactive Waste Management, Proceedings of the Fourth International Conference, Las Vegas, Nevada, (DATE): LaGrange, Illinois, American Nuclear Society, v. 2, p. 1559-1566.

Peterman, Z.E., and Stuckless, J.S., 1993b, Application of strontium and other radiogenic tracer isotopes to paleohydrologic studies, Paleohydrological Methods and their Applications: Paris, Proceedings of an NEA Workshop, November 1992, p. 59-84.

Pyke, C.B., 1972, Some meteorological aspects of the seasonal distribution of precipitation in the western United States and Baja California: University of California Water Resources Center, Contribution 139, $205 \mathrm{p}$.

Quade, J., Mifflin, M.D., Pratt, W.L., McCoy, W., and Burckle, L., 1995, Fossil spring deposits in the southern Great Basin and their implications for changes in water-table levels near Yucca Mountain, Nevada, during Quaternary time: Geological Society of America Bulletin, v. 107, p. 213-230.
Quade, J., and Cerling, T.E., 1990, Stable isotopic evidence for a pedogenic origin of carbonates in trench 14 near Yucca Mountain, Nevada: Science, v. 250, p. 1549-1552.

Quade, J., Cerling, T.E., and Bowman, J.R., 1989, Systematic variations in the carbon and oxygen isotopic composition of pedogenic carbonate along elevation transects in the southern Great Basin, United States: Geological Society of America Bulletin, v. 101, p. $464-475$.

Quade, Jay, 1986, Late Quaternary environmental changes in the upper Las Vegas Valley, Nevada: Quaternary Research, v. 26, no. 3, p. 340-357.

Quade, Jay, and Pratt, W.L., 1989, Late Wisconsin groundwater discharge-Environments of the southwestern Indian Springs Valley, southern Nevada: Quaternary Research, v. 31, no. 3, p. 351-370.

Riggs, A., 1984, Major carbon-14 deficiency in modern snail shells from southern Nevada springs: Science, v. 224 , p. $58-61$.

Robison, J.H., 1984, Ground-water-level data and preliminary potentiometric-surface maps, Yucca Mountain and vicinity, Nye County, Nevada: U.S. Geological Survey Water-Resources Investigations Report 84-4197.

Roedder, Edwin, Whelan, J.F., and Vaniman, D.T., 1994, Fluid-inclusion homogenization and crushing studies of calcite veins from Yucca Mountain, Nevada, tuffs-Environment of formation in High Level Radioactive Waste Management, Proceedings of the Fifth International Conference, Las Vegas, Nevada, (DATE): LaGrange, Illinois, American Nuclear Society, p. $1854-1860$.

Sarna-Wojcicki, A.M., Meyer, C.E., Wam, E., and Soles, S., 1993, Age and correlation of tephra layers in Owens Lake drill core OL-92-1 and -2, in Smith, G.I., and Bischoff, J.L., eds., Core OL-92 from Owens Lake, southeast California: U.S. Geological Survey OpenFile Report 93-683, p. 183-245.

Sass, J.H., Lachenbruch, A.H., and Mase, C.W., 1980, Analysis of thermal data from drill holes UE-25a \#3 and UE-25a \#1, Calico Hills and Yucca Mountain, Nevada Test Site: U.S. Geological Survey Open-File Report 80-826, 25 p.

Savard, C.S., and Beck, D.A., 1994, Transmission losses in Fortymile Wash near Yucca Mountain, Nevada: Eos, v. 75, no. 44, p. 283.

Smith, G.I., 1976, Paleoclimatic record in the upper Quaternary sediments of Searles Lake, California, U.S.A., in Horie, S., ed., Paleolimnology of Lake Biwa and the Japanese Pleistocene 4: Japan, Kyoto University, p. 577-604. 
Smith, G.I., 1993, Field log of core OL-92, in Smith, G.I., and Bischoff, J.L., eds., Core OL-92 from Owens Lake, southeast California: U.S. Geological Survey Open-File Report 93-683, p. 1-57.

Smith, G.I., and Street-Perrott, F.A., 1983, Pluvial lakes of the western United States, in Wright, H.E., ed., Late Quaternary environments of the United States: Minneapolis, University of Minnesota Press, chapter 10, p. 190-212.

Spaulding, W.G., 1977, Late Quaternary vegetation change in the Sheep Range, southern Nevada: Journal of the Arizona Academy of Sciences v. 22, p. 183-188.

Spaulding, W.G., 1981, The late Quaternary vegetation of a southern Nevada mountain range: Tucson, University of Arizona, unpublished Ph.D. dissertation, $271 \mathrm{p}$.

Spaulding, W.G., 1985, Vegetation and climates of the last 45,000 years in the vicinity of the Nevada Test Site, south-central Nevada: U.S. Geological Survey Professional Paper 1329, 83 p.

Spaulding, W.G., 1990, Vegetational and climatic development of the last glacial maximum to the present, in Betancourt, J.L., Van Devender, T.R., and Martin, P.S., eds., Packrat middens-The last 40,000 years of biotic change, chapter 9: Tucson, University of Arizona Press.

Steele, R., 1990, Pinus flexilis James Limber Pine, in Burns, R. M. and B. H. Honkala (Technical Coordinators), Silvics of North America: Volume 1, Conifers. Agriculture Handbook 654: Forest Service, United States Department of Agriculture, p. 348-354.

Stuiver, M., Long, A., Kra, R.S., and Devine, J.M., 1993, Extended ${ }^{14} \mathrm{C}$ data base and revised CALIB $3.0{ }^{14} \mathrm{C}$ age calibration program: Radiocarbon, v. 35 , p. 215-230.

Szabo, B.J., and Kyser, T.K., 1990, Ages and stable-isotope compositions of secondary calcite and opal in drill cores from Tertiary volcanic rocks of the Yucca Mountain area, Nevada: Geological Society of America Bulletin, v. 102, p. 1714-1719.

Thompson, R.S., 1991, Pliocene environments and climates in the western United States: Quaternary Science Reviews, v. 10, p. 115-132.

Thompson, R.S., Witlock, C., Bartlein, P.J., Harrison, S.P., and Spaulding, W.G., 1993, Chapter 18: Climatic changes in the western United States since 18,000 yr. B.P., in Wright, H.E., Jr., J.E., Kutzbach, T. Webb III, W.F. Ruddiman, F. a. Street-Perrott and P.J. Barlein (eds.), Global Climates since the Last Glacial Maximum: University of Minnesota Press, Minneapolis, Minnesota, pp. 468-513.

United States Air Force, Headquarters, Tactical Air Command, 1986, Final environmental impact statement, Groom Mountain Range, Lincoln County, Nevada: HQ_TAC/LEEV.
Van Devender, T.R., Martin, P.S., Thompson, R.S., Cole, K.L., Jull, A.J.T., Long, A., Toolin, L.J., and Donahue, D.J., 1986, Fossil packrat middens and the tandem accelerator mass spectrometer: Nature, v. 317, p. 610-613.

Waddell, R.K., Robison, J.H., and Blankennagel, R.K., 1984, Hydrology of Yucca Mountain and vicinity, Nevada-California-Investigative results through mid1983: U.S. Geological Survey Water-Resources Investigations Report 84-4267, 72 p.

Wells, P.V., and Berger, R., 1967, Late Pleistocene history of coniferous woodland in the Mohave Desert: Science, v. 155 , no. 3770, p. 1640-1647.

Wells, P.V., and Jorgensen, C.D, 1964, Pleistocene wood rat middens and climatic change in the Mohave Desert-A record of juniper woodland: Science, v. 143 , no. 3611, p. 1171-1174.

Wells, P.V., and Woodcock, D., 1985, Full-glacial vegetation of Death Valley, California-Juniper woodland opening to Yucca semidesert: Madrono, v. 32, p. 11-32.

Whelan, J.F., and Stuckless, J.S., 1990, Reconnaissance $\delta^{13} \mathrm{C}$ and $\delta^{18} \mathrm{O}$ data from Trench 14, Busted Butte, and drill hole G-4, Yucca Mountain, Nevada Test Site: Las Vegas in High Level Radioactive Waste Management, Proceedings of the First International Conference, Las Vegas, Nevada, (DATE): LaGrange, Illinois, American Nuclear Society, p. 930-934.

Whelan, J.F., and Stuckless, J.S., 1992, Paleohydrologic implications of the stable isotopic composition of secondary calcite within the Tertiary volcanic rocks of Yucca Mountain, Nevada: Las Vegas in High Level Radioactive Waste Management, Proceedings of the Third International Conference, Las Vegas, Nevada, (DATE): LaGrange, Illinois, American Nuclear Society, p. 1572-1581.

Whelan, J.F., Moscati, R.J., Allerton, S.B.M., and Marshall, B.D., 1996, Applications of isotope geochemistry to the reconstruction of Yucca Mountain paleohydrology: U.S. Geological Survey Milestone Report 3GQH257M to DOE-YMPSCO.

Whelan, J.F., Vaniman, D.T., Stuckless, J.S., and Moscati, R.J., 1994, Paleoclimatic and paleohydrologic records from secondary calcite-Yucca Mountain, Nevada, in High-Level Radioactive Waste Management, Proceedings of the Fifth International Conference, Las Vegas, Nevada, 1994: LaGrange, Illinois, American Nuclear Society, p. 2738-2745.

Winograd, I.J., and Doty, G.C., 1980, Paleohydrology of the southern Great Basin with special reference to water-table fluctuations beneath the Nevada Test Site during the late(?) Pleistocene: U.S. Geological Survey Open-File Report 80-569, 91 p. 
Winograd, I.J, Riggs, A.C., and Coplen, T.B., 1998, The relative contribution of summer versus cool season precipitation to recharge to the Spring Mountains, Nevada, Hydrogeology Journal, v. 6 (1), p. 77-93.

Winograd, I.J., and Szabo, B.J., 1988, Water-table decline in the south-central Great Basin during the Quaternary-Implications for toxic waste disposal, in Carr, M.D., and Yount, J.C., eds., Geologic and hydrologic investigations, Yucca Mountain, Nevada: U.S. Geological Survey Bulletin 1790, p. 147-152.

Winograd, I.J., Copeland, T.B., Landwehr, J.M., Riggs, A.C., Ludwig, K.R., Simmons, K.R., Szabo, B.J., Kolesar, P.T., and Revesz, K.M., 1992, Continuous 500,000 -year climate record from vein calcite in Devils Hole, Nevada: Science, v. 258, p. 255-284.
Winograd, I.J., Szabo, B.J., Coplen T.B., Riggs, A.C., and Kolesar, P.T., 1985, Two-million-year record of deuterium depletion in Great Basin ground waters: Science, v. 227, p. 519-522.

Winograd, I.J., Szabo, B.J., Coplen, T.B., and Riggs, A.C., 1988, A 250,000-year climatic record from Great Basin vein calcite-Implications for Milankovitch Theory: Science, v. 142, p. 1275.

Winter, T.C. and Woo, M.K., 1990, Hydrology of lakes and wetlands, in Wolman, M.G., ed., Surface water hydrology, in the collection The geology of North America: Boulder, Colo., Geological Society of America, 0-1, chap. 8, p. 159-187. 